\title{
Of Arsenic and Old Laws: Looking Anew at Criminal Justice in Late Imperial China
}

\section{Citation}

William P. Alford, Of Arsenic and Old Laws: Looking Anew at Criminal Justice in Late Imperial China, 72 Calif. L. Rev. 1180 (1984)

\section{Published Version}

http://scholarship.law.berkeley.edu/californialawreview/vol72/iss6/2/

\section{Permanent link}

http://nrs.harvard.edu/urn-3:HUL.InstRepos:12786001

\section{Terms of Use}

This article was downloaded from Harvard University's DASH repository, and is made available under the terms and conditions applicable to Other Posted Material, as set forth at http:// nrs.harvard.edu/urn-3:HUL.InstRepos:dash.current.terms-of-use\#LAA

\section{Share Your Story}

The Harvard community has made this article openly available.

Please share how this access benefits you. Submit a story.

Accessibility 


\section{California Law Review}

Volume 72 | Issue 6

Article 2

December 1984

\section{Of Arsenic and Old Laws: Looking Anew at Criminal Justice in Late Imperial China}

William P.Alford

Follow this and additional works at: http://scholarship.law.berkeley.edu/californialawreview

\section{Recommended Citation}

William P. Alford, Of Arsenic and Old Laws: Looking Anew at Criminal Justice in Late Imperial China, 72 CAL. L. Rev. 1180 (1984). Available at: http://scholarship.law.berkeley.edu/californialawreview/vol72/iss6/2

This Article is brought to you for free and open access by the California Law Review at Berkeley Law Scholarship Repository. It has been accepted for inclusion in California Law Review by an authorized administrator of Berkeley Law Scholarship Repository. For more information, please contact jcera@law.berkeley.edu. 


\title{
Of Arsenic and Old Laws: Looking Anew at Criminal Justice in Late Imperial China
}

\author{
William P. Alford $\dagger$
}

The Chinese have a long-standing tradition of using history to

$\dagger$ Acting Professor of Law, University of California, Los Angeles. B.A. 1970, Amlierst College; LL.B. 1972, University of Cambridge; M.A. 1974, Chinese Studies, Yale University; M.A. 1975, Chinese History, Yale University; J.D. 1977, Harvard University. In the course of researcling and writing this Article, I lave been fortunate to lave received inspiration and guidance from colleagues, mentors, friends, and students here and abroad all too numerous to mention individually. I would, however, be gravely remiss were I not to single out for special thanks Dean Susan Westerberg Prager and Professors Richard L. Abel, Kenneth L. Karst, Arthur I. Rosett, Gary T. Schwartz and Phillip R. Trimble of the U.C.L.A. Schoo' of Law; Professors Richard Baum of the Political Science Department and E. Perry Link of the East Asian Languages and Cultures Departunent of U.C.L.A.; Mr. Chang Wejen (Director) and Ms. Cecilia Kuo-ying Hsu of the Legal History Project of the Institute of History and Philology of the Academia Sinica; Jerome A. Cohen, Esq., formerly Professor of Law and Director of East Asian Legal Studies at the Harvard Law School; Dr. Fu-inei Chang Chen of the Hoover Institution on War, Peace and Revolution at Stanford University; Professor Andrew C.K. Hsieh of the History Department of Grinnell College; Professor Jonathan D. Spence of the Department of History of Yale University; Stanley B. Lubinan, Esq.; my parents, Dr. Hyman and Mrs. Rose Alford; and iny wife, Ms. Anna Marie Howell.

I also want to thank the many students whose questions and insights have tested and helped clarify my thinking about China's legal tradition. In particular, I an grateful for the very talented help of my research assistants, Ms. Fiona A. Comiell and Mr. David B. Kay in the final stages of this project.

Special thanks also go to my secretary, Ms. Genevieve Gilbert-Rolfe, who endured endless revisions with unceasing good lumor.

Finally, I want to thank the East Asian Legal Studies Program of the Harvard Law School, the History Department of Yale University, the American Historical Association, the Dean's Fund of the U.C.L.A. School of Law, and the U.C.L.A. Academic Senate for financial support; the directors and staffs of the Far Eastern Law Section and the Asian Division of the Library of Congress, the Harvard-Yenching Library, the Fu Ssu-nien Library of the Academia Sinica, the U.C.L.A. Law Library, the University Researclı Library at U.C.L.A., and the Center for Chinese Studies at the University of California, Berkeley for bibliographie assistance; and the Harvard Law School and Trinity College (Conn.) for inviting me to present lectures concerning a part of the researcl upon which this Article is based.

All translations are mine, unless otherwise noted, save for expressions and titles routinely translated in a particular fashion. I have used the Wade-Giles method for romanizing Chinese, with the exception of names of political figures, authors, and publications (other than reprints of historical works) in the People's Republic of China [hereinafter PRC] now regularly romanized according to the pinyin method, and a sinall number of other names routinely romanized according to other methods. Naturally, I reinain responsible for any opinions expressed and errors contained lierem.

The California Law Review wishes to express its gratitude to Mr. David B. Kay for his invaluable and extraordinary help in citeclecking the Chinese sources. 
comment upon contemporary events.' The Great Proletarian Cultural Revolution (the Cultural Revolution) ${ }^{2}$ is said to have been ignited in the People's Republic of China (PRC) by a play ${ }^{3}$ about an autocratic Ming dynasty (1368-1644) Emperor that was construed as commenting obliquely upon Chairman Mao Zedong. ${ }^{4}$ The massive effort launched in 1973 to discredit the inemory of Mao's designated successor, Lin Biao $^{5}$ and attack Premier Zhou Enlai ${ }^{6}$ took the form of a nationwide campaign to "criticize Lin, criticize Confucius," even though Confucius

1. J. Pusey, Wu Han: Attacking the Present Through the Past (1969); Oxnam, The Past is Still Present, in The China Difference 59 (R. Terrill ed. 1979). The Chinese use the idiom chih sang ma huai (literally, "to point at the mulberry and revile the ash") as a metaphor for the practice of commenting on the present by analogy to historical events or persons. J. PUSEY, supra, at 72.

2. The Great Proletarian Cultural Revolution, which is described in the PRC as having lasted from 1966 to 1976 , is generally agreed by Chinese and Western seholars alike to have been highly disruptive of normal political, social and economic life in the PRC. See On Questions of Party History: Resolution on Certain Questions in the History of Our Party Since the Founding of the People's Republic of China adopted June 27, 1981 at the Sixth Plenary Session of the 11th Central Committee of the Chinese Communist Party, Chinese text in Renmin Ribao [The People's Daily], July 1, 1981, English translation in 24 Beising REv. No. 27, July 6, 1981, at 10, 20-26. The Beijing Review is published weekly in English and a nnmber of other foreign languages by the Chinese government for international dissemmation. For further backgronnd on the Cultural Revolution, see L. Dittmer, Liu ShaO-Ch'i and the Chinese Cultural Revolution: The Politics OF MASS CRITICISM (1974).

3. See generally J. PUSEY, supra note 1. Interestingly, the play's author, Wu Han, who was vilified during the Cultural Revolution, has recently been celebrated in the PRC press as a "famous Marxist historian" laving "ontstanding "ethics." Zliang Xikong, In Praise of Comrade Wu Han's Ethics as a Historian, Renmin Ribao [The People's Daily] Oct. 22, 1984 at 5, reprinted in Foreign Broadcast Information Service Daily Report: China, Nov. 2, 1984 at K25, K27.

4. The definitive biography of Mao Zedong (1893-1976) has yet to be written. Recent works on his life include J. Ch'EN, MaO AND the ChInese Revolution (1965); L. Pye, MaO Tse-tung: The Man in the Leader (1976); S. Schram, MaO Tse-tung (1968); R. Terrill, MaO: A Blography (1980); and D. Wilson, The People's Emperor (1980).

5. A veteran of the Long Marcl, Lin Biao rose to prominence in Chinese Communist military circles as the commander of the celebrated Fourth Road Army during the Civil War, and subsequently held increasingly important positions, mcluding those of Vice Premier (1954), Field Marshal (1955), Politburo member (1958), and Minister of Defense (1959), before being designated as Vice Chairman of the Chinese Communist Party and Mao's successor in 1969. Soon therafter, lie fell from favor and is said to have died in a plane crash in Mongolia in 1971, having fled after an abortive effort to seize power. I. Hsü, THE RISE OF MODERN CHINA 620, 649, 712-22 (3d ed. 1983); M. MeISNer, Mao's China: A History of the PEOPle's RePUblic 362-75 (1977). See generally Wu Tien-wei, Lin Blao and the Gang of Four (1983); Yao Ming-Le, The Conspiracy and DeATH of Lin Biao (1983).

6. Born into a gentry family in 1899 and educated in China, Japan and France, Zlou Enlai served as Premier of the PRC from its establishinent in 1949 until his death in 1976 and as Foreign Minister from 1949 to 1958. Notwithstanding Zloou Enlai's long tenure in these positions and apparent broad support among the populace, the criticisms made of Confucius during the pi Lin, pi Kong movement are believed to have been an effort "to liarass [him] by allusion." I. HsÜ, supra note 5, at 776; Gray, Chou En-lai, in CAMbridge ENCyclopedia of China 280 (B. Hook ed. 1982); Wren, China Embraces a Heritage Once Banned as Reactionary: A Return to the Thoughts of Confucius, N.Y. Times, Oct. 14, 1984, at E7. 
had been dead for more than 2500 years. $^{7}$ And when the Guangming Ribao (The Enlightenment Daily) ${ }^{8}$ wished last year to counsel that China be more deinanding in its dealings with foreign business, it chose to inake its point by praising Wei Yuan, a conservative scholar-official of the nineteenth century known for advocating a policy of controlling one set of so-called "barbarians" with skills learned from other "barbarians."

For centuries, China's long legal history was hardly a favored vehicle for latter-day political comment by Chinese observers, be they Confucian or Communist in orientation. Of late, lowever, both highlevel officials and political commentators, writing with the blessing of the government, have seen fit to buttress their arguments about the contemporary scene with brief discourses on the nature of China's legal tradition. ${ }^{10}$ In an apparent effort to distance the present government from the excesses of the Cultural Revolution and to justify current efforts to develop the PRC's formal criminal justice process, ${ }^{11}$ these coin-

7. Confucius was born in 551 B.C. and died in 479 B.C. During the course of the campaign against Lin Biao and Confucius, Mao Zedong raised not a few eyebrows in the PRC and sent not a few Western "Pekingologists" scurrying to their history books when, endeavoring to nake a point regarding current political affairs, he declared that Ch'in Shih-huang-ti, the long-loathed first einperor of China, was really not so bad, after all. Almost as nysteriously as it began, the campaign against $L$ in and Confucius ended in March 1974. Lin Biao continues to be excoriated, but of late, the virtues of Confucius have again been extolled. See Wren, supra note 6, at E7.

8. Guangming Ribao is considered "a newspaper for more educated readers." Id.

9. Parks, Critics Blast China Policy on Investing: Lively Debate over 'Open-Door' Stance Stalls Needed Rule, L.A. Times, Oct. 24, 1983, § 1V, at 1, col. 1. Wei Yuan (1794-1856) is best known for coinpiling in 1844 what Professor Immanuel Hsu lias called "the first significant Chinese work on the West"-HAI-KUO T'U-CHH [AN ILLUSTRATED GAZETTRER OF THE MARITIME COUNTRIES]. I. Hsü, supra note 5, at 275-77. At the outset of that encyclopedic work, Wei Yuan asks rhetorically why he undertook this massive study and answers his own question by saying that "[i]t is for the purpose of using barbarians to attack barbarians, using barbarians to negotiate with barbarians, and learning the superior techniques of the barbarians to control the barbarians." Id. at 276 (I. Hsu trans.) (einphasis in Hsu translation). The use of the term "barbarians" to refer to foreigners emanates from long-standing Chinese notions of cultural superiority. See generally The Chinese World Order: Traditional China's Foreign Relations (J. Fairbank ed. 1968).

10. See, e.g., Address of Peng Zhen, entitled Explanation on Seven Laws, delivered at the Second Session of the Fifth National People's Congress on June 26, 1979, English translation published in 22 Beunng Rev. No. 28, July 13, 1979, at 8; Zhu Yuanshi, The Causes of the "Cultural Revolution," 24 Beunva Rev. No. 37, Sept. 14, 1981, at 15; Prospect and Retrospect: China's Socialist Legal System, 22 Beuing Rev. No. 2, Jan. 12, 1979, at 25; see also Cohen, Introduction to Essays on China's Legal Tradition 3, 4 (J. Cohen, R. Edwards \& F. Chang Chen eds. 1980) [heremafter cited as Cohen, Introduction].

11. The leading Western work on the criminal justice process during the early years of the PRC is J. Cohen, The Criminal Process in the People's Republic of China, 1949-1963: AN Introduction (1968) [heremafter cited as J. Cohen, Criminal Process]. Also particularly useful for that period, although quite different in their orientation, are LENG SHAO-CHUAN, JUSTICE IN COMMuNist CHINA (1967); V. LI, LAW Without LaWYers: A CoMparative VIEW OF LAW IN China AND tHe United STATEs (1978); and Lubman, Form and Function in the Chinese Criminal Process, 69 Colum. L. Rev. 535 (1969). Among the most thoughtful accounts of the PRC's recent 
mentators have told an international audience that the success of Lin Biao and the "Gang of Four" 12 was largely attributable to a tradition of using law as a tool to repress, rather than proinote, individual justice and freedom. ${ }^{13}$ In the words of one noted PRC legal historian, China's legal heritage, and particularly that of the Ch'ing dynasty (1644-1912), has left her with an "arduous task different from [that of] other . . . socialist countries." 14

efforts to develop further her criminal justice process are Gelatt, The People's Republic of China and the Presumption of Innocence, 73 J. CRIM. L. \& CRIMINOLOGY 259 (1982); Leng, Crime and Punishment in Post-Mao China, CHINA L. ReP., Spring 1982, at 5; Lubman, Emerging Functions of Formal Legal Institutions in China's Modernization, in CHINA UNDER THE FOUR MODERNIZAtions: Part II-Selected Papers Submitted to the Joint Economic Committee of the Congress of the United States 235 (J. Hardt ed. 1982); and R. Baum, China's Post-Mao Legal Reforns in Historical and Comparative Perspective (June 1984) (unpublished paper available at the U.C.L.A. Law Library).

12. Soon after the death of Chairman Mao Zedong on September 9, 1976, his successor Hua Guofeng ordered the arrest of four political figures prominent in the Cultural Revolution. The most notorious member of this group, which the Chinese press soon labeled the "Gang of Four," was Mao's widow, Jiang Qing. Its three other members were Zhang Chunqiao, who served as Vice Premier, Politburo member, and Mayor of Shanghai; Wang Hongwen, the youug factory worker who became a ranking Politburo nember and who was at one time spoken of as a potential successor to Mao; and Yao Wenyuan, who was Shanghai Party Secretary and head of the central government's propaganda apparatus. Yao's denunciation of Hai Rui Dismissed From Office, the play by Wu Han alluded to supra in note 3, is said to have launched the Cultural Revolution.

After almost four years of detention, Jiang, Zhang, Wang and Yao were placed on trial together with six other figures active during the Cultural Revolution-Chen Boda, Huang Yongsheng, Wu Faxian, Qiu Huizuo, Jiang Tengjiao, and Li Zuopeng-for allegedly committing a variety of counterrevolutionary acts. On January 23,1981 , each defendant was found guilty of the principal charges of which he or she stood accused, although some were acquitted of certain of the lesser charges. Jiang Qing and Zhang Chunqiao were each given a sentence of "death with a twoyear reprieve" which, after the two years expired, was converted to life imprisonment. This uuusual sentence, which has antecedents in Chinese legal history back to the Han dynasty (206 B.C.220 A.D.) provided that the death sentence be suspended for a two-year period in order to give the convicted the opportunity to reforn sufficiently to merit a lesser penalty than death. The other eight defendants received sentences of imprisonment ranging from 17 to 20 years. The trial itself is discussed in A GREAT TRIAL IN ChINESE History (1981); Edwards, Introduction to The Gang of Four Trial: Chinese Criminal Justice in Practice, CHINA L. REP., Fall 1981, at 173; Goodstadt, The Trial of the "Lin-Jiang Cliques": China's Return to the Rule of Law?, 12 HoNG Kong L.J. 31 (1982); Symposium: The Trial of the "Gang of Four" and Its Implication in China, in 3 OccASional Papers/Reprint Series in Contemporary Asian Studies (J. Hsiung ed. 1981).

13. See commentaries cited supra in note 10.

14. Zhang Guohua, Chinese Legal Thought Before the Twentieth Century 13 (unpublislied manuscript available at the U.C.L.A. Law Library) [hereinafter cited as Zhang Guohua, Chinese Legal Thought].

The views of Professor Zhang, who is one of the PRC's most eminent scloolars of the history of Chinese legal thought, are set out at greater length in such works as Zhang Guohua, Cong lishishang tan fazhi de liangge wenti [A Discussion of Two Questions Concerning the Legal System from the Viewpoint of History], in I FALÜSHI LUNCONG [COLLECTED EsSAYS ON LEGAL HISTORY] 27 (1981) and in Zhongguo Falu Sixiang Shi [A History of Chinese Legal Thought] (Zhang Guohua ed. 1982) [hereinafter cited as ZhaNG GuOHUA, History OF LEGAL THOUGHT]. His critique of justice provided by the imperial state, particularly during later years of the Cling dynasty (which ruled Chima from 1644-1912 A.D.), ought not to lead us to infer that he believes 
Comparable views have also had wide currency in academic and popular circles in the West for much of the past two centuries. ${ }^{15}$ Leading authorities on Chinese law, ${ }^{16}$ eminent general historians of China, ${ }^{17}$ and influential nonsinologists ${ }^{18}$ continue to portray the formal criminal

China's legal tradition to have been wholly bleak. He has words of praise, for example, for indi-

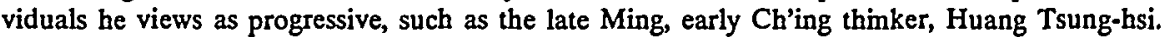
See Zhang Guohua, Chinese Legal Thought, supra, at 4-5. Professor Zhang's characterization of the quality of late $\mathrm{Ch}$ 'ing justice is shared by many other distinguished PRC legal historians. See, e.g., Zhang Deze, Qingdal Guojia Jiguan Kaolüe [A BRIEF Examination of Qing DyNASTY GOVERNMENT ORGANIZATION] 1 (1981) (written before the Cultural Revolution but not published until 1981); Zhang Jinfan, ZhaNG XIPo \& ZeNG XIANY1, 1 Zhongguo FazHI SHI [CHINESE Legal History] 408-56 (1981).

15. See infra notes $16-18,54-97$ and accompanying text.

16. See J. Cohen, Criminal Process, supta note 11, at 5-7; Cohen, Chinese Mediation on the Eve of Modernization, 54 CALIF. L. REv. 1201, 1212-15 (1966) [hereinafter cited as Cohen, Chinese Mediation]; Cohen, Introduction, supra note 10, at 7-8. But see Cohen, Due Process?, in The China DifFerence, supra note 1, at 237, 256-57. For other authorities' portrayals of the imperial criminal process as essentially an instrument of state control little concerned with individual justice, see J. Brady, Justice and Politics in People's China 34-37 (1982); S. VAN DeR Sprenkel, Legal Institutions in Manchu China 66-79 (1962); Barlow \& Wagner, Public Order and Internal Security, in CHINA: A Country Study 427 (F. Bunge \& R. Shinn eds. 1981); Gelatt, supra note 11, at 263-65, 307; Jones, Theft in the Qing Code, 30 AM. J. CoMP. L. 499, 501 (1982); Lubman, Mao and Mediation: Politics and Dispute Resolution in Communist China, 55 Calif. L. Rev. 1284, 1290-91 (1969); Tay, Law in Communist China-Part I, 6 Sydney L. Rev. 153 (1969); see also Kamenka \& Tay, Social Traditions, Legal Traditions, in LAw AND Social Control 3, $21-24$ (E. Kamenka \& A. Tay eds. 1980). Ch'ul T'ung-tsu's highly useful work, Law and Society in Traditional China, should also be included in this group. Although an earlier version was published in China in 1947, the version most influential in the West was subsequently revised and published by Dr. Ch'u in the Umited States. $C_{H}$ 'Ü T'UNO-TSU, LAW AND SOCIETY IN TRaditional China 283-87 (1959) [hereinafter cited as Ch'U T'UNO-TSU, LAW AND SocietY]. Interestingly, im his other important work in English, CH'U' T'UNG-TSU, LOCAL GoverNMENT IN China UNDer the CH'ING (1962) [hereinafter cited as CH'Ü T'UNG-TSU, LoCal GovernMENT], Professor Ch'u is far less judgmental in discussing imperial lcgal history. Whether that is attributable to its different focus (legal administration rather than substantive law) or to later authorship is unclear.

17. See, e.g., J. Fairbank, The United States and China 117-23 (4tl ed. 1979); I. Hsü, supra note 5, at 52-53; L. PYE, China: An Introduction 60-61, 71 (2d ed. 1978); R. SMith, China's Cultural Heritage: The Ch'ng Dynasty 1644-1912, at 42, 240 (1983); L. Stover, The Cultural Ecology of Chinese Civilization 89-94 (1974); K. WittFogel, Oriental Despotism: A Comparative Study of Total Power 1, 131-33, 144-45, 158-59 (1959); Mote, Political Structure, in THE Modernization of ChINA 47, 97-99 (G. Rozman ed. 1981); Schwartz, On Attitudes Toward Law in China, in GoverNMENT UNDER LAW AND THE INDIVIDUAL 27, passint (M. Katz ed. 1957); see also J. Ch'En, China AND the WeSt: Society and Culture 1815 1937, at 316, 324-27 (1979); M. Hunt, The Making of a Special Relationship: The United States AND China to 1914, at 1-2 (1983).

18. See, e.g., A. Bozeman, The Future of Law in a Multicultural World 140-47 (1971); R. David \& J. Brierly, Major Legal Systems in the World Today 28-29 (2d ed. 1978); R. Unger, LaW In MOdern Society: Toward a CRITICism of Social Theory 48-110 (1976); Forte, Western Law and Communist Dictatorship, 32 EMORY L.J. 135 (1983); Kamenka \& Tay, supra note 16, at 22-24; Noda, The Far Eastern Conception of Law, in 2 INTERNATIGNAL ENCYCLOPEDIA OF COMPARATIVE LAW ch. 1, at 120, 126-27 (1975). Many of the foregoing authors treat imperial Chinese legal history in broad sweeps as if it were a single unified whole, with little distinction either among periods or between substance and procedure. For exainple, Roberto Unger claims at one point to be focusing chiefly upon the period prior to the umification of China 
justice process ${ }^{19}$ in late imperial China ${ }^{20}$ as having been essentially an instrument of state control little concerned with individual justice. ${ }^{21}$ To be sure, many of these scholars have greatly advanced our understanding of China's law and legal history through their work. Still, in so doing, whether exphcitly or otherwise, ${ }^{22}$ they have painted a picture of Ch'ing "law and legal institutions . . . principally as instruments for inamtaining the power of the state rather than enhancing the sense of security of its citizens." 23

Ironically, for all the certainty with which the late imperial criminal justice process has been presented in the West over the past two centuries, ${ }^{24}$ we still know far too hittle about either the theory or operation of that process. ${ }^{25}$ This inay be attributable to the lingering effects

in 221 B.C., R. UNGER, supra, at 87, but he has no hesitancy at other points in extending his generalizations, at least by inplication, to cover essentially the following two millenia of Chimese legal history. Id. at 86 (suggesting that China and the rest of the non-European world stayed inired in "customary law" or "bureaucratic law" until modern Europe was sufficiently generous to spread what he describes as the concept of a "legal order" to the godless). It is encouraging to see that Professor Unger las inade at least a modest start in his most recent work at righting the distorted picture he imparted of the Chinese past in Law in Modern Society. See R. UnGer, Passion: AN EsSay ON PERSONALITY 64-69 (1984). I address Professor Unger's treatinent of the Chinese past at length im a manuscript now in progress.

19. As used in this Article with respect to inperial China, the term formal crininal justice process refers to the process by which disputes involving the public, positive criminal laws of the inperial Clinese state were adjudicated by inperial officials pursuant to procedural and administrative rules of the state, in contrast to unofficial dispute resolution conducted by persons other than officials.

20. China's imperial period is typically dated from the unification of China by the Ch'm dynasty (221 B.C.) to the Revolution of 1911 A.D., which toppled the Cl'ing dynasty in 1912. The late inperial period upon which this Article is focused inay be thought of as approximately the last century of Ch'ing rule.

Scholars disagree about when written law first arose in China. The noted archaeologist Chang Kwang-chih suggests that elements of a legal systen may liave existed in what was to becoine China as early as the Sliang dynasty (1766-1122 B.C.). Chang Kwang-Chih, Shang Civilization 200-01 (1980). The historian Herrlee Creel believes that a coinprehensive legal systein developed during the Western Chou dynasty (1122-771 B.C.). H. CReEL, THE ORIGINS of Statecraft in China: The Western Chou Empire 161-95 (1970). Still others look to later dates. In any event, it is clear from The Analects of Confucius that at least by the sixth century B.C. the notion of formal written law was widespread. See, e.g., THE ANALECTS of Confucius Books II-3, XII-12, XII-13, XIII-3 (A. Waley trans. 1938).

21. Although there is as yet no fully satisfactory definition of justice in inperial China, for purposes of this Article justice will be assuned to consist of the conviction of the guilty and the acquittal of the innocent. See J. Wu, Chinese Legal and Political Philosophy, in THE CHINESE Mind: Essentials of Chinese Philosophy and Culture 213, 228 (C. Moore ed. 1967).

22. For example, many have focused upon the absence or relative unimportance in inperial China of aspects of criminal justice processes in the West widely thought to be vital to the attaininent of justice. For a inore complete discussion of such features, see infra text accoinpanying notes 58-80.

23. Colien, Introduction, supra note 10, at 7-8.

24. See supra notes $16-18$; infra notes $39-46,48$ and accoinpanying text.

25. Lubman, Western Scholarship on Chinese Law: Past Accomplishments and Present Challenges, 22 Colum. J. Transnat'L L. 83 (1983) and Jones, Book Review, 30 Am. J. Comp. L. 
of the seeming disdain of Confucian-oriented scholar-officials for law, ${ }^{26}$ to the absence of systernatic, official case reporting, ${ }^{27}$ or to the sheer difficulty of securing, reading, and evaluating the pertinent original source materials. ${ }^{28}$ But whatever its cause, notwithstanding the important efforts of a small number of specialists both here ${ }^{29}$ and

555 (1982) (reviewing Essays on China's Legal Tradition (J. Cohen, R. Edwards \& F. Chang Chen eds. 1980)) usefully discuss the state of current Western scholarship in the field of Chinese legal studies. See also J. FAIRBANK, supra note 17, at 107; Zhang Guohua, Chinese Legal Thought, supra note 14, at 1-2.

26. D. Bodde \& C. Morris, Law in lmperial China 19-23 (1967).

27. Id. at 144-59.

28. Scholars of American law accustomed to finding neatly printcd coinprehensive collections of cases, statutes, and relatcd materials in a law hbrary might initially find it hard to comprehend the bibliographic efforts involved in undertaking serious work in Chinese legal history. The Chinese did unaintain detailed records of imperial activities, such as the Tung-hua lu [Records from Within the Tung-hua Gate], see infra note 32 and Appendix $A$, and the Shih lu [Veritable Records], see infra Appendix $A$. Such voluminous collections of official documents, which have neither tables of contents nor indexes, by no means, however, discuss all legal matters outside the Einperor's immediate purview. As a consequence, it is necessary for a scholar wishing to cover virtually any area of Chinese legal history in any depth to have recourse to a range of additional materials, access to which-or even the existence of which-is not always ccrtain. Too often, such inaterials are scattered throughout the world, assembled chronologically (if at all) and handwritten, rather than printed. For a discussion of the range of materials utilized in undertaking the rcsearch for this Article, see infra Appendix $A$.

Once the necessary documents have been assembled, one's work really begins, in part owing to linguistic diffieulties. See D. BODDE \& C. MORRIS, supra note 26, at 3. Official imperial documents were written in classical Chinese, a complex allusion-filled language bearing a relation to contemporary Chinese roughly akin to that Latin bears to Italian. Unofficial sources including confessions, diaries, and novels often contain colloquial language peculiar to the speakcr or author's native region and period which pose their own difficulties of translation and interprctation. Furthcr comphicating the picture with respect to either type of document is the fact that there still is no good Chinese-English legal dictionary dealing with matters of legal history that might coinplement Philip Bilancia's excellent work foeused on the period froin 1939 to 1977 . See P. Bilancia, Dictionary of Chinese Law and Government (1981); see also D. Bodde \& C. MORRIS, supra note 26 , at 156-59. In the absence of a comprehensive dictionary for matters of legal history, the inost useful works available are P. BILANCIA, supra; Ch'ING AdMINISTRATIve Terms: A Translation of the Terminology of the Six Boards With Explanatory Notes (E-tu Zen Sun trans. \& ed. 1961) [hereinafter cited as E.Z. Sun, Ch'ing Terms]; W. MAYERS, The Chinese Government: A Manual of Chinese Titles, Categorically Arranged and Explained (3d ed. 1896); Present Day Political Organization of China (H. Brunnett \& V. Hagelstroun trans. 1912). E-tu Zen Sun's work is a translation of Liu-pu ch'eng-yll chu-chieh [Terminology of the Six Boards with Explanatory Notes], which was a dictionary of terms and phrases used in the conduct of the imperial bureaucracy during the Ch'ing dynasty. E.Z. SuN, CH'ING TERMS, supra, at xvii. The glossaries found in D. BODDE \& C. MORRIS, supra note 26, at 577-93; Essays on China's Legal Tradition, supra note 10, at 395-423; and T. METzGer, The lNTERNal Organization of the Ch'ing Bureaucracy: Legal, Normative and Communication ASPECTS 451-65 (1973) are also very helpful.

29. See, e.g., D. BODdE \& C. MORRIs, supra note 26; T. METZGER, supra note 28; J. OCKO, Bureaucratic Reform in Provincial China: Ting Jih-ch'ang in Restoration Kiangsu, 1867-1870 (1982); J. WatT, The District Magistrate in LATE IMPerial China (1972); Fu-mei Chang Chen, The Influence of Shen Chih-ch'i's Chi Chu Commentary upon Ch'ing Judicial Decisions, in EsSAYS ON CHINA'S LEgAL TRADITION, supra note 10, at 170 [hereinafter cited as Chen, Shen Chih-ch'i]; Fu-mei Chang Chen, On Analogy in Ch'ing Law, 30 HARv. J. Asiatic Stud. 212 (1970) [hereinafter cited as Chen, On Analogy]; Edwards, Ch'ing Legal Jurisdiction over Foreign- 
abroad ${ }^{30}$ research im Chinese legal history remams at too preliminary a

ers, in EsSAYS ON ChINA's Legal Tradition, supra note 10, at 222; Ocko, Justice on Appeal: The Capital Appeals System in Ch'ing China, forthcoming in LAW and THE State IN TraditionaL EAST AsIA (B. McKnight ed.); A. Conner, The Law of Evidence During the Ch'ing Dynasty (1979) (unpublished doctoral dissertation, Cornell University) (available from University Microfilms International, Ann Arbor, Michigan).

Finally, although I take issue with their overall characterization of the formal criminal justice process in late inperial China, Jerome Cohen, Stanley Lubman, William Jones and others among the scholars mentioned supra in notes 16-18 have made major contributions to our understanding of traditional and contemporary Chinese law. Indeed, without the ground-breaking scholarship and ongoing unselfish encouragement of younger scholars by Messrs. Cohen, Lubinan and Jones, among others, articles such as this would not be possible.

30. The most notable such work abroad has taken place on Taiwan and in Japan. Typical of the inost important scholarship undertaken on Taiwan are: 1 CHANG WEJEN, Ch'ING-TAI FACHIH YeN-ChIU [RESEARCh ON THE Legal SySTEM OF THE Ch'ing DYNASTY] (3 vols. 1983) [hereinafter cited as Chang Wejen, Legal System]; Hsü DAU-Lin, ChuNg-Kuo FA-ChIH-ShIH LUN-ChI [COLlECTED ESSAYs ON ChINESE LEgAL History] (posthumously published in 1975); T'ao Hsi-sheng, Ch'ing-tai Chou-hsien Yamen Hsing-shin Shen-pan Chih-tu Chi Chenghsü [The System and Procedure for Resolving Judicial Matters at the District Level DuRINg the Ch'ing Dynasty] (1972) [hereinafter cited as T'Ao Hsi-sheng, The SYSTEM].

Major Japanese work in this field has been undertaken by Shuzo Shiga and Shigeo Nakamura. For Shiga, see Shiga, Criminal Procedure in the Ch'ing Dynasty with Emphasis on Its Administrative Character and Some Allusion 10 Its Historical Antecedents, in Memolrs of THE Research of The Toyo Bunko No. 32, at 1 (1974) [hereinafter cited as Shiga, Criminal Procedure (I)]; and id. No. 33, at 115 (1975) [hereinafter cited as Shiga, Criminal Procedure (II)], which save for additions to its footnotes, were originally published in Japanese as Shiga, Shincho Jidai no Keiji Saiban-Sono Gyōseiteki: Jakkan no Enkakuteki Kōsatsu o Fukumete, in KelHATSU to KoKka KenRyokū [Punishment AND STATE Power] (Hoseishi Gakkai ed. 1960) (Japan Legal History Association), and Shiga, Shindai ni Shihō no okeru Hanketsu no Seikaku-Hanketsu no Kakutei to iu Kannen no Fusonzai [The Nature of Judicial Decisions in Ch'ing China: Lack of the Concept of Res Judicata], in HōGAKU KYōKaI ZasshI [J. LEGAL STUdies] No. 91, at 47 (1974); and id. No. 92, at 1 (1975). I am indebted to Professor Shiga for having met with ine to discuss Ch'ing legal history. For Nakamura, see NAKAMURA, Shindal KeIHō KENKYU [STUdies ON Ch'ING CRIminal LAw] (1973); Shindai no Hango ni Mirareru Hō no tekiyō: Toku ni Bukoku, Ikakuninchishi o Megutte [Application of Law in the Ch'ing Dynasty as Seen in Judgments, Especially Concerning Cases of False Accusations and of Intimidation Leading Persons to Suicide], 9 Hōsei RiRon [Legal THEory] 1 (1976). I am grateful to Ms. Emily deLeeuw of the U.C.L.A. School of Law for drawing my attention to Professor Nakamura's work.

Interestingly, although the great historian Niida Noboru and other Japanese scholars have written extensively about pre-Ch'ing legal history, "virtually none has devoted primary effort to the Ch'ing dynasty or in particular codified [as opposed to customary] law." D. BODDE \& C. MORRIS, supra note 26, at 54. Indeed, as Professors Bodde and Morris point out, even that volume of CHŪGOKU HŌSEISHI KENKYū [THE STUDY OF CHINESE LEGAL HisTORY] (Niida's epic series on the history of Chinese law) devoted to criminal law "says extremely little about the evolution and structure of the Ch'ing Code ... [or] about Ch'ing judicial procedure," as it focuses chiefiy on earlier dynasties. D. BODDE \& C. MORRIS, supra note 26, at 55.

European scholarship on imperial Chinese legal history has principally been devoted to dynasties prior to the Ch'ing. To a far greater extent than its United States counterpart, it consists of annotated translations and focuses upon questions of substantive or customary rather than procedural law. For example, see Paul Ch'en's reconstruction of the Yüan Code, P. CH'EN, CHINESE Legal TRadition UNDER THE MONgols (1979); Jean Escarra's overview of Chinese law, J. Escarra, Le Droit ChinoIs [ChINESE LAW] (1936); Edouard Kroker's annotated translation of MIN-SHANG HSI-KUAN TIAO-CH'A PAO-KAO LU [REPORT ON THE INVESTIGATION OF CIVIL AND COMMERCIAL CUSTOM], a compilation of legal custoin published in 1930 by the Chinese governinent, E. Kroker, Die Amtliche Sammlung Chinesischer Rechtsgewohnheiten [The MiN- 
stage to warrant conclusive judgments about the character of the formal criminal justice process. ${ }^{31}$

This Article attempts to advance our understanding of the formal criminal justice process in late imperial China by reconstructing from archival materials and analyzing one of the most celebrated criminal cases in Chinese history-that of Yang Nai-wu and Hsiao-pai-ts'ai. ${ }^{32}$ It is a sign of the state of our explorations of the Chinese legal tradition that no Western scholar has ever written about the case, that no Chinese scholar has produced a definitive account of it and its overall significance, ${ }^{33}$ and that no scholar, Chinese or foreign, has yet charted in

ISTERIal COMPILATION OF Chinese Legal Custom] (1965); Marinius Meijer's study of the late Ch'ing law reform efforts, M. MEuER, The INTROduction of MOdern Criminal LAW IN ChinA (1949); and Frank Munzel's annotated translation of the first section of the hsing-fa-chih [monograph on criminal law] from the Standard History of the Ming Dynasty, F. MÚNZEL, Strafrecht im Alten China Nach den Strafrechtskapiteln in den Ming-ANnalen [Criminal LaW in Old China from the Monograph on Criminal LaW of the Mino anNALS] (1968).

31. See infra notes $306,399-432$ and accompanying text.

32. The case, which bears the name of its male principal, Yang Nai-wu, and a nickname of its female principal, Hsiao-pai-ts'ai, is one of four celebrated cases of the late imperial period known as the four great injustices of the late Ch'ing dynasty. In reconstructing this case, I have utilized a broad range of sources, including records of the imperial state, diaries of prominent officials, journalistic accounts of the case, informal contemporaneous private treatuncnts, and a wide variety of other primary and secondary sources. Although I urge readers to refor throughout their reading of the Article to the bibliographic essay that constitutes Appendix $A$ for a full treatment of the nature and relative reliability of the sources utilized, it is worth briefly describing here the six sources upon whicl I lave drawn most heavily in reconstructing the case. The first and inost comprehensive is the KUANG-HSÜ CH'AO TUNG-HUA LU [RECORDS FROM WITHIN THE Tung-hua Gate for the KuANG-hsÜ ReIGN] (Chu Shou-p'eng ed. 1958) (Beijing reprint) [heremafter cited as TUNG-HUA RECORDS], a quasi-official state history containing excerpts of official documents, the utility of which is limited by its heavily pro-imperial bias and emphasis upon the lighest levels of government. (All citations to the Tung-hua lu use the consecutive pagination of the 1958 edition). The second is the HSIN-TSENG HSING-AN HUI-LAN [A NEW SuPPLEMENT to THE Conspectus of PeNal Cases] (P'an Wen-fang \& Hsul Chien-ch'uan eds. I886) [hereinafter cited as A NEW SUPPLEMENT TO THE CONSPECTUS], a "cascbook" put together in the 1880 's by individuals drawing upon official arclives in which this and more than 250 other cases are summarized. The third and fourth key sources are diaries of the late Cli'ing officials, Weng T'ung-ho and Li Tz'u-ming. Weng T'ung-ho Jih-ChI [THE Diary OF Weng T'Ung-ho] (Chao Chung-fu ed. 1960) (Taipei reprimt) [heremafter cited as WENG T'UNG-Ho, DIARY]; LI Tz'U-MING YÜEH-MAN T'ANG JiH-CHI [DIARY OF THE YÜEH-MAN HALL] [hereinafter cited as LI Tz'U-MING, DIARY]. As is explained in Appendix $A$, Weng's diary is considered a better source than Li's, but both need to be treated witl a great deal of care, given Weng's involvement in the case and Li's provincial ties. The fifth major source is the Shen Pao, a lively, if not always accurate, newspaper owned by a British merchant and edited by Clinese. Published in Shanghai, the Shen Pao took a strong and partisan interest in this case. The sixth is a roughly contemporaneous unofficial history of administration durmg the Kuang-hsul reign that draws heavily upon memorials and other records of officials at the Board of Pumishments. KuANG-HSÜ CHENG-Yao [IMPORTANT Policies OF THE KUANG-HSÜ REIoN] (Shen T'ung-sheng ed. 1969) (Taipei reprint) [hereinafter cited as IMPORTANT POLICIES].

33. In 1967, Cliao K'e-chun published in Ch'ün-ch'iu, a Taiwan journal, the only substantial piece in any language regarding the case. Chao K'e-clidn, Ch'ing-mou tsui hung-tung te i-jian ylian-yli [The Most Explosive Injustice of the Late Ch'ing], 4 CH'ÜN-CH'lu [SPRINo \& AUTUMN] 15 
meaningful and explicated detail the full course of any imperial Chinese case that traversed the entire formal criminal justice system from the level of the district magistrate to the highest reaclies of the imperial government. ${ }^{34}$

Obviously, one must proceed with caution wlien striving to generalize about any legal process on the basis of a single case, even though many contemporaneous observers saw it as reflecting, albeit in a pronounced form, difficulties plaguing the late imperial criminal justice process. $^{35}$ Nonetheless, the case of Yang Nai-wu and Hsiao-pai-ts'ai provides us with an unparalleled opportumity to witness and understand that process. Replete with allegations of adultery, inurder, and politically inotivated cover-ups, as well as witlı courageous efforts to see justice done, the case has spawned folktales, short stories, novels, plays, a full-length feature film, and even a Peking opera, whicl are theinselves potentially fruitful sources of further information about Chinese attitudes toward law. ${ }^{36}$ Even inore important, it proinpted both participants and contenporaneous outside observers to produce extensive accounts of the case. ${ }^{37}$ From these accounts, along with inore skeletal and scattered records available in archives here and in East Asia, it is now possible to construct the single most coinprehensive example of the imperial Chinese criminal justice process in operation, and through it to enhance our understanding of the nature of that process generally.

Part I of this Article will examine briefly the inanner in which the formal criminal justice process in late imperial China has been and continues to be portrayed today, particularly in the West. Because of the coinplexity of the case, because that coinplexity helps us appreciate the character of traditional Chinese law, and because there are no coinparable reconstructed examples of the imperial criminal justice process in action, Part II of this Article will portray the full history of this case

(1967) [hereinafter cited as Chao K'e-chün, Injustice]. That article and others concerning the case are discussed briefly in Appendix $A$.

34. Jonathan Spence's fine study, The Death of Woman Wang, exainines the murder of a poor peasant woman during the early Ch'ing dynasty but Professor Spence has "deliberately tried to keep the story both rural and local." J. Spence, The Death of Woman Wang at xi (1978). Shuzo Shiga has carefnlly and lucidly described many features of the late imperial crininal justice process in Shiga, Criminal Procedure (I), supra note 30, and in Shiga, Criminal Procedure (II), supra note 30. The inost comprehensive general discussion of the criminal justice process and personnel in late imperial China may be found in 1 Chang Wejen, Legal SYstem, supra note 30; see also the works discussed supra in notes 16-18, 29-30, 32 and in Appendix $A$

35. See infra notes $213-15,254-57,306,322-23,370-77$ and accompanying text; see also Chao K'e-chün, Injustice, supra note 33, at 15.

36. Examples include novels such as KAO YANG, HSIAO-PAI-TS'AI (1975) and HuANG NANtING, YANG NAI-wU (1952), and the Peking opera, Yang Naimu yu Xiao Baicai, which was performed in the PRC in 1980 and again in 1982.

37. See Appendix $A$. 
from its commencement im Yü-hang district, Chekiang province in $1873,{ }^{38}$ to its conclusion in the imperial capital of Peking some four years later. Part III of this Article utilizes the case as a vehicle to examme the late imperial formal criminal justice process as it was meant to work and as it actually did work. The Article concludes by considermg the case's implications for the image now prevalent in the West of that process, and by raising many questions that remain for scholarly inquiry.

\section{The Prevailing Image}

We ought not to be surprised at the prevailing image in the West of the criminal justice process in late imperial China as essentially an mstrument of state control little concerned with the attainment of individual justice. For most of the past two centuries, widely differing commentators have characterized the process in this manner, either directly or by treating the entire late imperial state as an authoritarian monolith essentially uninterested in law, other than as command. The list of these unlikely bedfellows includes: Montesquieu ${ }^{39}$ and others ${ }^{40}$ reacting to the largely uncritical portrayals of China by Voltaire ${ }^{41}$ and fellow sinophiles; ${ }^{42}$ European and American merchants, nnissionaries, and diplomats ${ }^{43}$ in China concerned with the potential effect of the process upon themselves and upon Chinese with whom they dealt; ${ }^{44}$ West-

38. Yu-hang is located in the northeastern corner of Chekiang, virtually equidistant-70 miles-froin Hangchow and Shanghai. P. GeELAW \& D. TwitcheTt, THE TIMEs ATLAS of CHINA 51 (1974). It is a part of the Yangtze delta region which traditionally has been one of the great centers of Chinese culture and an area of relative affluence. Ho PING-Tl, STUDIES ON THE Population of China, 1368-1953 (1959).

39. See, e.g., C. Montesquieu, De L'Espirit Des Lois [The Sirit of Laws] Livre XII, Chapitre VII (1748).

40. See L. Maverick, China: A Model for Europe 112-38 (1946); A. Reichwein, China and EuRope: Intellectual and ARTistic Contacts in the Eighteenth Century 91-98 (1925).

41. See Rowbotham, Voltaire sinophile, 47 Publication Mod. Language A. Am. 1050-65 (1932).

42. The exponents of such views included $\mathrm{Du}$ Halde, Leibniz, Spinoza, and Wolff, among others. See R. Dawson, The Chinese Chameleon: An Analysis of European Conceptions of Chinese Civilization 54-55, passim (1967); A. Reichwein, supra note 40, at 73-110.

43. See, e.g., J. DoolitTle, Social Life of the ChINESe 335-41 (1856); R. Douglas, SocIety IN China (1895); C. GützLAfF, Sketch of Chinese History 34-53 (1834); 2 M. Huc, A Journey Through the Chinese Empire $229-67$ (1855); J. MacGowan, Sideliohts ON CHINESE LIFE 272-96 (1907); G.L. MACKAY, FROM FAR FORMOSA 105-06 (1896); 1 S. WILLIAMS, THE Midde Kingdom 507 (1883); see also Cohen, Chinese Mediation, supra note 16, at 1211-12. See generally the accounts of Chinese criminal procedure from issues of the China Repository, reprinted in 2 G. Keeton, The Development of Extraterritoriality in China 229 (1928).

44. In an effort to win and protect Chinese converts, Western missionaries "resorted to the practice of offering converts monetary subsidies and protection against offlcial and unofficial interference and insult . . . . When these converts became involved in trouble and lawsuits, the mis- 
ern governments reluctant to part with the extraterritorial privileges enjoyed by their nationals; ${ }^{45}$ prominent nineteenth- and early twentieth-century Western social theorists; ${ }^{46}$ late nineteenth- and early twentieth-century Chinese nationahists hoping to build a new social and pohtical order; ${ }^{47}$ and Karl Marx, ${ }^{48}$ Mao Zedong ${ }^{49}$ and others ${ }^{50}$ eager to effect sociahst revolution in China. To be sure, during the past twentyfive years, a few intrepid scholarly explorers working here ${ }^{51}$ and abroad $^{52}$ have unearthed evidence suggesting that criminal law in late imperial China was richer, more complex, and less easily dismissed

sionaries often came to their aid, interceding with magistrates on their behalf." I. Hsü, supra note 5, at 388. As might be imagimed, these converts, who were mockingly called ch'h-chiao [literally "eat by rehgion" or "rice Christians"] were often not well-received by their fellow Chimese. Id. at $388,392$.

45. To understand "extraterritoriality," it is necessary to review briefly the early history of Sino-British legal relations. The unfavorable reaction of British merchants and officials during the late 18th and early 19th centuries to Chinese justice, which differed appreciably from the British counterpart, was a precipitating factor in the Opium War (1839-1842). Edwards, supra note 29 , at 222, 242-43, 245-52, 260. As a consequence, in the Treaty of Nanking, which officially ended the Opiun War, the British obtained the right to have British law applied extraterritorially in China by British officials to British subjects accused of having committed crimes agamst Chinese. Id. at 242. During the next half contury, this principle was extended to include certam civil

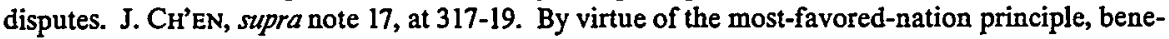
fits of extraterritoriality enjoyed by one foreign nation were granted to numerous others-including the United States, France, Germany, and Russia. W. FlShel, The END of EXTRATERRITORIALITY IN CHINA 1-25 (1952). The last privileges of extraterritoriality were not given up by the United States until 1943. Id. at 1 . Needless to say, extraterritoriality was profoundly humiliating to the Chinese. See, e.g., J. Wu, The Problem of Extraterritoriality in China, in THE ART OF LAW 72 (1936).

46. See, e.g., G. HeGEL, The Philosophy of History 116-38 (J. Sibree trans. 1899); J.S. Mill, Letter to Edwin Chadwick (Mar. 13, 1857), in 15 Collected Works of John Stuart Mill 528 (F. Mineka \& D. Lindley eds. 1972); M. Weber, WirTschaft und Gesellschaft (2d ed. 1925), translated in LAW IN ECONOMY AND SOCIETY 263-65 (E. Shils \& M. Rheinstein trans., M. Rheinsteim ed. 1954).

47. Sce, e.g., K'ANG YU-Wei, The Great COMMONweAlTH Book VIII, cli. 14, translated in TA T'Ung-Shu, The ONe-World Philosophy of K'ANG YU-Wei (L. Thompson trans. 1958); Wang T'ao, On Domestic Administration, translated in TENG SsU-YÜ \& J. FaIRBanK, ChINA's RESPONSE TO THE WEST 139 (1954) [hereinafter cited as CHINA's RESPONSE]; see also infra note 377.

48. Marx, Revolution in China and in Europe, N.Y. Daily Tribune, June 14, 1853, reprinted in K. MARX, ON CoLONIALISM (1972). Marx, of course, foresaw revolution coming first in the industrialized West and generally viewed China as lying beyond the civilized world. He recognized, however, that there had been a massive popular uprising in the 1mid-19th century and was hopeful that "the Chinese revolution will throw the spark into the overloaded mine of the present industrial systein [which] will be closely followed by political revolutions in the [European] continent." Id. at 24.

49. See Mao Zedong, Report on an Investigation of the Peasant Movement in Hunan, in 1 Selected Works OF MAO TSE-TUNG 23 (1967).

50. See, e.g., Ch'en Tu-hsiu, Shi-hsing min-chih te chi-ch'u [The Basis for the Realization of Democracy], in 7 HsIN CH'ING-NIEN [NEW YOUTH] 14 (1919) and Li Ta-chao, Ta-ai p'ien [The Great Grief], in L1 TA-CHAo HsüAN-CHI [SELECTEd WoRKS OF LI TA-CHAO] 2-3 (1959).

51. See supra note 29.

52. See supra note 30. 
than has typically been thought. Unfortunately, their important findings have not yet led to a transformation of the way in which the forinal criminal justice process is inost typically portrayed in the West.

Before turning to the case of Yang Nai-wu and Hsiao-pai-ts'ai, it will be useful to survey those aspects of the traditional Chinese legal system upon which Western scholars have focused in portraying the process as a tool of state control having little to do with individual justice. ${ }^{53}$ Essentially, these nay be grouped into four broad categories: the intermingling of administrative, adjudicatory and other authority, particularly in the hands of the district magistrates; ${ }^{54}$ the 1naimer in which trials were to be conducted; 55 the tenor of the substantive laws administered througl the process; ${ }^{56}$ and the absence of any belief annong the populace that the process was a vehicle for securing justice. ${ }^{57}$ Because the summaries of these categories are composites drawn froin the work of a range of scholars, some of whom touch upon the process but briefly, it would be a mistake to conclude that any single scholar whose work is cited subscribes to all the views raised, or necessarily even to a majority of them.

The lack of a separation of powers, particularly at the level of the district magistrate, is the feature of the imperial criminal justice process that seems to have had the greatest impact upon Western scholars critical of the process. ${ }^{58}$ Within each of the approximately 1500 districts ${ }^{59}$ that comprised late imperial China, a single official, the district magistrate, presided over some 200,000 to 250,000 residents $^{60}$ as the principal embodiment of imperial authority. The nagistrate was responsible for all aspects of civil governance, ${ }^{61}$ including such seemingly diverse matters as the collection of taxes, the maintenance of public order, and the investigation, prosecution, and adjudication of crimmal matters. To many Western scholars, this aggregation of authority, and the concomitant absence of any imdependent judicial or administrative official at the district level from whom the populace could seek recourse, carried

53. See infra notes 54-97 and accompanying text.

54. See infra notes 58-61 and accompanying text for a brief discussion of the position of district magistrate, and notes 62-68 for a consideration of the further concern of Western scholars about the lack of separation of powers at the magisterial level.

55. See infra notes $69-80$ and accompanying text.

56. See infra notes $81-88$ and accompanying text.

57. See infra notes $89-97$ and accompanying text.

58. See, e.g., J. Cohen, Criminal Process, supra note 11, at 5-7; J. Fairbank, supra note 17 , at 122; I. Hsü, supra note 5, at 52-53; S. VAN DER SPRENKEL, supra note 16, at 70; Kamenka \& Tay, supra note 16, at 23; Lubman, supra note 16, at 1292; Mote, supra note 17, at 97-98.

59. Hsiao Kung-chuan, Rural China: Imperial Control in the Nineteenth CenTURY 3-6 (1960). The number of districts varied among and within dynasties.

60. See, e.g., Ho PING-T1, supra note 38, at 282, passim, for figures on late Ch'mg population.

61. J. WATT, supra note 29, at 11-22, passim. For more on the position of district magistrate, see infra notes 160, 261, 292-94 and accompanying text. 
with it enormous potential for the inagistrate's unrestrained assertion of state power. ${ }^{62}$ Some scholars believe that this potential was realized all too often ${ }^{63}$ or that, even when it was not, fear of its realization had a chilling effect upon potential litigants. ${ }^{64}$ Actually, the Ch'ing possessed an elaborate system of checks upon the exercise of magisterial discretion, most of which operated from above..$^{65}$ Although they were neither exclusively directed toward the formal criminal justice process nor necessarily thought of as a group, the function of these checks was to ensure that magistrates properly exercised their considerable responsibilities in this and other areas. Whether attributable to a relative lack of familiarity with certain of these checks ${ }^{66}$ or to an inherent skepticism about the ability of a system that had no separation of powers at its highest levels to right abuses by officials at lower levels, ${ }^{67} \mathrm{few}$ commentators have devoted serious attention to these checks and to the effect they may have had as inutually reinforcing restraints upon inagisterial behavior. ${ }^{68}$

A second major element of the formal criminal justice process that has inclined contemporary Western scholars to view it as an instrument of state control little concerned with the attainment of individual justice is the manner in which the process was to be conducted at the magisterial level. Although legal matters were an important part of the magistrate's responsibilities, ${ }^{69}$ few magistrates had any serious training in law prior to assuming office. Legal knowledge was neither tested on the inperial examinations to be taken by candidates for office, nor seen as particularly worthy of study by would-be scholar-officials. ${ }^{70} \mathrm{~A}$ highly detailed set of laws and rules existed, however, to guide magis-

62. See generally sources cited supra in note 58 .

63. See, e.g., J. Cohen, Criminal Process, supra note 11, at 6.

64. See infra notes $89-92$ and accompanying text.

65. These checks will be described and illustrated in detail below. See infra notes 291-305 and accompanying text; text accompanying notes 140-290.

66. Even the most comprehensive Western study of late imperial Chinese criminal law, Law in Imperial China by Derk Bodde and Clarence Morris, mentions the possibility of appeals by litigants only in passing. D. BODDE \& C. MORRIS, supra note 26, at 118.

67. See, e.g., J. Cohen, Criminal Process supra note 11, at 6; S. VAN DeR SPREnkel, supra note 16, at 70; Mote, supra note 17 , at $97-98$.

68. With the notable exception of Ch'u T'ung-tsu, see CH'U T'UNG-TSU, LOCAL GoverNMENT, supra note 16, none of the scholars mentioned supra in notes 16-18 devote more than passing attention to these procedures and measures, and none suggest that the checks could have imposed any significant restraint upon magistrates exercising their authority in legal matters.

69. Legal matters were one important basis upon which inagistrates were evaluated for possible promotion. See J. WATT, supra note 29, at 174-75.

70. Id. at 23-25; Cohen, Chinese Mediation, supra note 16, at 1212; Lubman, supra note 16, at 1292,1295 . Michael Walzer has suggested that by the late $\mathrm{Ch}$ 'ing, the imperial examination inay have been better at testing exam-taking skills than knowledge of the Confucian Classics. M. Walzer, Spheres of Justice: A Defense of Pluralism and Equality 141 (1983). For more on the imperial examinations, see infra notes 105-08. 
trates in discharging their responsibilities. ${ }^{71}$ These legal guidelines prescribed an inquisitorial inode of adjudication that encoinpassed little of what we see today as fundamental procedural "due process."72 Persons accused of crimes were not presuined to be innocent; ${ }^{73}$ nor were they entitled to notice, either of the law ${ }^{74}$ or of their alleged crimes. ${ }^{75}$ They were allowed neither to consult legal counselors (known as sung-kun ${ }^{76}$ ) during trial, nor to refuse to answer the magistrate's inquiries. ${ }^{77}$ Indeed, magistrates were perimitted to apply torture ${ }^{78}$ in order to secure confessions. ${ }^{79}$ And neither the evidence gathered nor reports prepared by the magistrate at trial's end were necessarily made available to the accused. ${ }^{80}$

71. See infra notes $292-94$ and accompanying text.

72. J. Cohen, CRIMINal Process, supra note 11, at 5-7; 1. HsÜ, supra note 5, at 52; Forte, supra note 18, passim; Tay, supra note 16, passim.

73. Gelatt, supra note 11, at 263-65.

74. Editions of imperial laws and regulations published by the state were generally for offcial use only. Although a few private editions were published as well, these do not appear to have been readily available to private persons. T. METzGeR, supra note 28, at 146-50. In any event, throughout imperial Chinese history, a vast majority of the population was illiterate (although some imperial edicts were read aloud from time to time by village elders). Contrary to the prevailing inpression in the West, the Chinese took pains prior to the Opiun War to give notice of Chinese laws to foreigners on the supposition that such persons could otherwise not be familiar with them. Edwards, supra note 29, at 243-45.

75. Ch'ing law did not require that the magistrate fully apprise persons before him of the specific crimes of which they stood accused.

76. I. Hsü, supra note 5, at 52; J. FaIRBANK, supra note 17, at 120 . The term sung-kun (literally, "litigation cudgel," but generally translated as "litigation trickster") was a pejorative one used to describe individuals who earned their livelihood by preparing petitions and other papers for persons involved in legal matters. They generally had no formal legal training but often either lad acquired direct experience with legal affairs by virtue of having worked on a magisterial staff or had, at least, been able to educate themselves through study of various speciatized private texts on law. 1 Chang WeJEN, Legal SySTEM, supra note 30, at 157; infra note 109. Some also held imperial degrees. See infra notes $108,308$.

In the absence of an officially recognized legal profession, the sung-kun were the principal private source of legal advice for the general populace. 1 CHANG WEJEN, LEGAL SYSTEM, supra note 30, at 157. The official attitude toward sung-kun is reflected in an imperial decree of 1820 , translated in Law in Imperial China and reproduced by Victor Li in Law Without Lawyers, that calls the sung-kun "rascally fellows [who] entrap people for the sake of profit. They fabricate empty words and heap up false cliarges . . . ." V. LI, supra note 11, at 19-20. Technically, it was not against Ch'ing law for a private individual to advise "a simple and uninformed person . . . and draw . . . up an infornation for him in the legal and . . . customary manner." TA Tsing Leu Lee [The CODE OF THE GREAT Ch'ING DYNASTY] \& 340 (G. Staunton trans. 1966) (Taipei reprint) [hereinafter cited as CH'ING CODE].

77. See, e.g., J. CohEN, CRIMINAL Process, supra note 11, at 6; R. SMITH, supra note 17, at 42.

78. Ch'U T'ung-TSu, Local Government, supra note 16, at 124-26; J. Cohen, CRiminal Process, supra note 11, at 6; S. VAN DER SPRENKel, supra note 16, at 68. Section 404 of the Ch'ing Code speaks, for example, of categories of persons the inagistrate was prohibited from torturing. CH'ING CODE, supra note 76, \& 404; see also infra note 293 and accompanying text; $A$. Conner, supra note 29, at 119-52.

79. J. Cohen, CRIMINal Process, supra note 11 , at 6 . But see infra note 161 .

80. Magistrates were required to submit written reports to their superiors in cases in which 
A third concern of Western scholars has been the nature of the substantive law administered through the process. That law was not framed in terms of individual rights and equality. Instead, it largely buttressed the authority of the imperial government and family. ${ }^{81}$ The law accorded vastly different treatinent to persons depending upon their relative statuses, ${ }^{82}$ with the inost crucial distinctions being those of ruler-subject, husband-wife, and father-son. ${ }^{83}$ For example, a father striking a son would receive a far less severe punishment than would a son striking a father, ${ }^{84}$ even if botll father and son were vigorous, healthy adults. Other features of late imperial Chinese law troubling to Western scholars have included the possibility it held for collective punishment, ${ }^{85}$ its broad definition of intent, ${ }^{86}$ and its catcli-all provisions outlawing that which "ought not to be done," 87 and permittimg the extension of criminal law by analogy. ${ }^{88}$

Fimally, the fourth major dimension of the formal criminal justice process noted by Western scholars was the apparent attitude of the Chimese populace as reflected im the writings of Emperors and highlevel officials, ${ }^{89}$ folk-wisdom, ${ }^{90}$ and the observations of nineteenth-cen-

they recommended the imposition of punishments greater than bambooing, see infra note 160 and accompanying text, but there was no requirement that copies of these reports be provided to the defendant.

81. J. FalRBANK, supra note 17, at 117-23; L. STOVER, supra note 17, at 89-90.

82. J. Cohen, Criminal Process, supra note 11, at 6-7.

83. D. BODDE \& C. MORRIS, supra note 26, at 33-38; CH'Ü T'UNG-TSU, LAW AND SOCIETY, supra note 16 , passim.

84. C'HÜ T'UNG-TSU, LAW AND SocietY, supra note 16, at 41-66; J. FAIRBANK, supra note 17 , at 121 .

85. In theory, at least, individuals could be punished for the misdeeds of others. Reflecting their lowly position in late imperial China, woinen could, for example, be sentenced to banishInent if their husbands received a sentence of exile. See CH'ING CODE, supra note 76, $\S 15$. Also, under the pao-chia systen (a system of population registration and crime-reporting) a person might be punished for failing to report the crimes of other families with which his family was grouped. Hsiao KUNG-CHUAN, supra note 59, at 42-83. It is not clear how often individuals were in fact held responsible for the crimes of other persons. Stover suggests that it may have been a frequent oceurrence. L. STOVER, supra note 17, at 91-92.

86. See, e.g., Forte, supra note 18, at 156. For an illustration of Western concern about the Chinese definition of intent, see the account of the Terranova case in M. HUNT, supra note 17, at 1-2. Randle Edwards' essay on Ch'ing treatment of foreigners inasterfully uses both Chimese and Western materials to portray the inutual difficulties of perception and understanding experienced in the late 18th and early 19th centuries as Western inerchants came into contact with the Chinese. Edwards, supra note 29, at 222.

87. See, e.g., J. Cohen, Criminal Process, supra note 11, at 6-7; see also Ch'ing Code, supra note $76, \S 386$.

88. See, e.g., D. BODdE \& C. MORRIs, supra note 26, at 32. But see Chen, On Analogy, supra

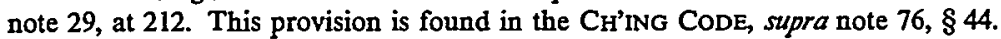

89. Particularly notorious, although not necessarily representative of other emperors, is the 1670 Sheng-yld [Sacred Edict] of the K'ang-hsi Emperor which, inter alia, harshly denounced those who would bring lawsuits. A portion of the edict is translated in Cohen, Chinese Mediation, supra note 16, at 1215. It is discussed in L. STOVER, supra note 17, at 90-94.

90. Drawing upon the writings of late 19 th- and early 20 th-century observers residing in 
tury Western merchants, missionaries, and diplomats. ${ }^{91}$ These sources portray the populace as viewing the process with trepidation, to say the least. ${ }^{92}$ This reaction may have arisen out of the awesomeness for most Chinese peasants of encounters with officialdom, ${ }^{93}$ a Confucian-oriented sense that resort to a formal legal remedy reflected moral failure, ${ }^{94}$ the corruption and venality of magisterial subalterns, ${ }^{95}$ the seemingly oppressive manner in which trials were to be conducted, ${ }^{96}$ or the severity of the substantive criminal law. ${ }^{97}$ Whatever the cause, many Western scholars have found hittle to suggest that the Chinese populace viewed the formal criminal justice process as a means through which individual justice might be secured.

II

\section{The Case Reconstructed}

\section{A. Murder in Yü-hang?}

At midmorning on November 28, 1873, Ko P'in-lien took to his bed, never again to arise. ${ }^{98} \mathrm{Few}$, if any, of his neighbors in the Yuhang district of Chekiang province could have imagmed how the unexpected death of this lowly bean-curd shop attendant would affect the lives of his wife Hsiao-pai-ts'ai, the dashing young scholar Yang Naiwu, a host of imperial representatives, and even the Einperor himself.

The story of the extraordmary chain of events set off by Ko's death must start with his marriage to Hsiao-pai-ts'ai some eighteen months earlier. ${ }^{99}$ The information available about this unschooled peasant wo-

China, Stanley Lubman and Sybille Van der Sprenkel each recount popular sayings regardimg the formal criminal justice process. Typical of them is the warning, "[D]on't eat anything poisonous and don't break the law." S. VAN DER SPRENKEL, supra note 16, at 135; Lubman, supra note 16, at 1296; see also $1 \mathrm{~S}$. WILLIAMS, supra note 43.

91. See, e.g., the sources listed supra in note 43 and accoinpanying text.

92. See, e.g., CH'Ü T'UNG-TSU, LAW AND SocIETY, supra note 16, at 284-85; V. LI, supra note 11, at 14; S. VAN DER SPRENKEL, supra note 16, at 77-78, 135; Gelatt, supra note 11, at 263-65; Lubman, supra note 16, at 1295-96; Schwartz, supra note 17, at 68.

93. L. STOVER, supra note 17, at 91; Kamenka \& Tay, supra uote 18, at 23.

94. J. CH'EN, supra note 17, at 316; CH'Ü T'UNG-TSU, LAW AND SoCIETY, supra note 16, at 284; I. Hsü, supra note 5, at 52-53; Cohen, Chinese Mediation, supra note 16, at 1206-07, 1214; Lubman, supra note 16, at 1291-92; Mote, supra note 17, at 96; Northrop, The Mediational Approval Theory of Law in American Legal Realism, 44 VA. L. REv. 347, 349 (1958).

95. J. Cohen, Criminal Process, supra note 11, at 6; L. Stover, supra note 17, at 92-93. Coheu, Chinese Mediation, supra note 16, at 1213-14; Lubman, supra note 16, at 1295-96; see also infra note 308.

96. See supra notes $69-80$ and accompanying text.

97. See supra notes $81-88$ and accompanying text.

98. See infra Appendix $B$ for a list of all individuals involved in this case.

99. IMPORTANT Policies, supra note 32, at 2:2. The account in Important Policies of the early aspects of the case consists of the verbatim reproduction of a final memorial submitted by the Board of Punishments in April of 1877 sketching briefly the history of the case before it reached the provincial capital. The memorial, most likely written by the Board President Tsao- 
man who was to become a legendary figure is, not surprisingly, sketchy and focused chiefiy on physical characteristics. ${ }^{100}$ Not one of the many sources even mentions her full name. All imstead refer to her as Mrs. $\mathrm{Ko}$, née $\mathrm{Pi}$, her formal married name, or, more typically, as Hsiao-paits'ai (meaning "little cabbage"101), a suggestive nickname given her because of the resemblance her appealingly plump figure bore to that late imperial Chinese symbol of feminine attractiveness. Those accounts of the case dwelling at all upon her agree that she was considered a woman of exceptional beauty not only by the inhabitants of her native Yü-hang but also by others who encountered her durmg the course of the case. ${ }^{102}$

The marriage of Hsiao-pai-ts'ai to Ko P'in-lien appears to have been one of convemence. Given his lowly position, it is unlikely that Ko P'in-lien could have secured a n1ore conventional marriage. ${ }^{103}$ Hsiao-pai-ts'ai's reputation for prommscuity made it highly doubtful that she could have expected a better mate than a bean-curd shop attendant. But whatever their motivations may have been, Hsiao-paits'ai's and Ko P'in-lien's marriage soon proved to be a troubled one. They lived on the edge of poverty and often quarreled bitterly. ${ }^{104}$

Owing to the couple's poverty and to the fact that Ko's father had died and his mother had remarried, Ko had no family home to which he might bring Hsiao-pai-ts'ai when they wed in April of 1872. Accordimgly, Ko arranged to rent a simgle room in a three-room house owned by Yang Nai-wu, a handsolne thirty-four year-old who had accomplished the impressive task of passing the second-level imperial ex-

pao, is not reprinted in either the Tung-hua Records or the Veritable Records, the two major sources for late Ch'ing domestic history. See supra note 32; infra Appendix $A$. It is, however, summarized in the Ching Pao [Peking Gazette], a gazette published by the imperial court contaiming official documents. The North China Herald and Consular Gazette, an Enghish language newspaper published in Shanghai, translated and reprinted selections from the Ching Pao under the heading Peking Gazette.

100. Ch'ing-Tal L1-Ch'ih Tsung-T'An [A Collection of WRItings on Government AdMINISTRATION DURING THE Ch'ING DYNASTY] 4:727-28 [hereinafter cited as WRITINGS ON ADMINISTRATION]; Yü-HANG TA-YÜ CHI [A HISTORY OF THE GREAT CASE OF Yü-haNG] [hereinafter cited as CASE HistoRY], reprinted in HUA-SUI-JEN-SHENG AN CHIH-I [RECollections FRom the HUA-SUI-JEN-Sheng Chamber] (Huang Chün comp. 1965) (Taipei reprint) [hereinafter cited as CHAMBer ReCOLLECTIONS].

101. See, e.g., Ch'ing pai Lei-CH'ao [Miscellaneous Records Concerning the Ch'ing DYNASTY] 227 (Hsa K'o ed. 1918) [hereinafter cited as Miscellaneous ReCORDs]; Writings on ADMINISTRATION, supra note 100, at 4:728-29; Shen Pao, Apr. 18, 1876; id., Mar. 3, 1877. For a glinpse of the enduring inportance of the cabbage in Chinese hife, see Bennett, Old Chinese Adage: No Hungry Winters If Lots of Cabbage, Wall Street J., Dec. 6, 1983, at 1, col. 3.

102. See, e.g., Shen Pao, Apr. 18, 1876.

103. Writings on ADMinistration, supra note 100, at 726.

104. IMPORTANt Policies, supra note 32, at 2:3a. 


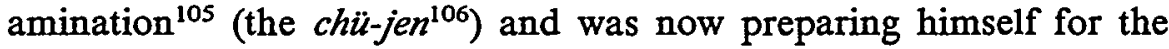
third and highest level (the chin-shih ${ }^{107}$ ) in anticipation of an official career. Although himself the son of a chü-jen, Yang had fallen upon hard times and so found it necessary to support himself and his fainily by writing coinplaints, petitions, and other legal documents for the local populace, ${ }^{108}$ and renting out that part of his home vacated since he had sent his wife and young child to stay with her parents in the countryside. ${ }^{109}$

Yang's work on behalf of the local populace had earned him a reputation as a shrewd legal craftsinan who was not above using his position as a neinber of the local degree-holding elite to advantage in his work. ${ }^{110}$ In so doing, Yang managed to antagonize both fellow members of the Yü-hang gentry and the local magistrate and yamen staff. ${ }^{111}$ The Yü-hang gentry apparently felt it demeaning not only that one of their class should earn his living writing legal complaints but, additionally, that he should do so in what was considercd an unprincipled, unmannered fashion. The local magistrate, Liu Hsi-t'ung, and his staff were reportedly irritated by the frequency and indclicacy with

105. Modern historians agree that the Chinese were the first people to use competitive examinations to select officials. Teng Ssu-yu, Chinese Infuence on the Western Examination System, 7 HARV. J. AsIATIC STUD. 267 (1943). Such examinations may have been offered as early as 1100 B.C. Id. at 268-70. In any event, they were given during the later Han dynasty (25-220 A.D.), and, after a long imterlude, on a fairly regular basis from 622 A.D. onward to 1905. Kracke, Family vs. Merit in Chinese Civil Service Examinations Under the Empire, 10 HaRv. J. Aslatic STUD. 103 (1947). Teng Ssu-yu has traced the imfluence of this method of selecting officials upon the British and American systems of civil service examinations. Teng Ssu-yú, supra, at 267.

106. The chio-jen, the second of the three major imperial degrees, was awarded to candidates successful on the provimcial level examination. According to a leading modern authority on the imperial examination system, "the chit-jen status was a crucial one in the stratification of MingCh'ing society," for those who held this degree were clearly marked as individuals of consequence within their comınunities. Ho PING-TI, THE LADDER OF SuCCESS IN IMPERIAL CHINA 26-27 (1962).

107. The chin-shih was the highest of the three major imperial degrees and was awarded only to a select nunber of individuals who perforned with distinction on an arduous examination offered every third year in Peking.

108. Yang Nai-wu was by no means the only holder of an imperial degree during this period who earned his living assisting the general populace in legal matters. Notwithstanding the existence of legal limitations upon the extent to which holders of the sheng-yitan (the first of the three inajor degrees) who were also known as licentiates, and meinbers of the local gentry could involve themselves in judicial matters to which they were not a party, many appear to have intervened. See infra hotes 139-41 and accompanying text; see also 1 CHANG WEJEN, LEGAL SySTEM, supra note 30, at 155; J. WATT, supra note 29, at 223; see also supra note 76; infra note 186.

109. LI Tz'U-MING, DIARY, supra note 32, at 4195.

110. Id. at 4194-95; Shen Pao, Dec. 29, 1875.

111. Li Tz'U-MING, DIARY, supra note 32, at 4194-95; WRITINGS ON ADMINISTRATION, supra note 100, at 4:727-28. The terun yamen refers to the magistrate's headquarters, which included the local court. For more on the position of district magistrate, see supra text accoinpanying notes 59 61; infra text accompanying notes 291-94. 
which Yang poimted out their errors and pressured them. ${ }^{112}$

The ill will that Magistrate Liu, his staff, and the local gentry bore toward Yang as a result of his legal work was exacerbated both by his personality and by the way in which he handled his private affairs. Even accounts of the case sympathetic to Yang indicate that he was a heady, often abrasive individual who had won himself many enemies im the years before his case arose. ${ }^{113}$ Yang also appears to have had a reputation in Yü-hang for having sown more than his share of wild oats as a young man. The tenor of his married life did little to dispel this reputation and, indeed, seems to have generated a series of rumors that made the accusations of adultery that were later leveled against him appear plausible in the eyes of many Yü-hang residents. ${ }^{114}$

Little is known about Ko P'in-lien and Hsiao-pai-ts'ai's first few months as tenants of Yang. By the sixth month following her marriage, however, Hsiao-pai-ts'ai and Yang had begun to spend a great deal of time im conversation while Ko P'in-lien was at work. ${ }^{115}$ In a statement made to officials during the case, Yang's wife said that Yang had told her that he spent most of his time with Hsiao-pai-ts'ai listening to her complamts about her husband and counseling her not to abandon her marriage. ${ }^{116}$ Whether this be true or not, the questionable propriety of such open and extended meetings between two married individuals soon became a topic of conversation among their neighbors and, as the stories spread, a source of suspicion to Ko. ${ }^{117}$

In order to test his suspicions, on at least two occasions Ko returned from the bean-curd shop at an earlier hour than usual and hid outside Yang's house. On the first occasion Ko overheard Yang attemptimg to teach Hsiao-pai-ts'ai passages from the Classics, and on the second he observed them eatimg and laughing together. ${ }^{118}$ With his suspicions heightened by the extraordinary sight of a chï-jen teaching the Classics to a poor peasant woman ${ }^{119}$ and by the intimacy suggested

112. According to one report, in the early 1870's Yang went so far as to lodge a complaint against Liu and his staff, accusing them of having siphoned off portions of the local grain tax. CASE HISTORY, supra note 100, at 358. Althongh there is no direct confirmation of this incident, the local gazetteer for Yu-hang does indicate that Liu Hsi-t'ung failed to complete two of the three separate terms he served as Yü-hang's magistrate. Yü-HANG HsIEN-CHIH KAO [THE LOCAL GAZETTEER FOR Yü-HANG DisTRICT] 2 (Chang Chi-an comp. 1919) [heremafter cited as Yü-HANG GAZETTEER].

113. CASE History, supra note 100, at 358; Li Tz'U-MING, DIARY, supra note 32, at 4194-95.

114. Shen Pao, May 22, 1876.

115. A New SuPplement TO THE CONSPECTUS, supra note 32, at 15:5145-46; IMPORTANT PoLICIES, supra note 32 , at 2:3a.

116. Shen Pao, Dec. 7, 1874.

117. IMPORTANT POLICIES, supra note 32, at 2:3a.

118. Id.

119. Regarded as a key to power and prestige thronghout Chinese history, hiteracy - and particularly knowledge of the Classics-was largely the domain of men until the late 19th century. Dnring the last few decades of that century, an increasing number of women from wealthy fami- 
by their casual sharing of a meal, Ko sought the advice and assistance of both his mother, Mrs. Shen, nee Yü, and his mother-m-law. Soon thereafter, Hsiao-pai-ts'ai's mother went to question her daughter about these matters, only to discover her once again light-heartedly sharing a meal with Yang. Spurred by his mother-in-law's report and perhaps by a recent rent increase, Ko P'in-lien decided that he and his wife should no longer live in Yang's house. ${ }^{120}$

During the summer of $1873 \mathrm{Ko}$ and his wife moved into a one room louse owned by Wang Hsm-p'ei, an elderly relative of Ko's stepfather. At Ko's urging, Wang agreed that while Ko was at the beancurd shop, he would keep an eye upon Hsiao-pai-ts'ai. ${ }^{121}$ Although Wang did not see Yang visit Hsiao-pai-ts'ai, he did report to Ko that during the daylight hours lie often saw ler leaving the house and that at times during the evening he could make out the sound of her door being opened and closed. ${ }^{122}$ Agitated by this inforınation, as well as by Hsiao-pai-ts'ai's recurrent complaimts about their marriage, on October $15,1873 \mathrm{Ko}$ was provoked by a sinall, unrelated incident to denounce Hsiao-pai-ts'ai for infidelity. ${ }^{123}$ When she demied his accusation, he beat her soundly, prompting her to cut off her hair and to declare that she would leave him in order to become a nun. News of that evening's events spread quickly, first to Ko's mother who later scolded her son for allowing himself to be carried away by his suspicions, and then to otler nembers of the neighborhood who had by now coine to think that this inarriage was a particularly ill-fated one.

The marriage was soon to end. While at hoine on November 26 , 1873, Ko complained to Hsiao-pai-ts'ai that he felt hot and tired and that his legs had begun to swell and discolor. ${ }^{124}$ Rejecting her advice that he stay at liome and rest, Ko went to work that day and each of the next two, although lie felt worse as time passed. By mid-morning on the twenty-eighth, however, Ko felt so ill that he decided to leave work and return to his house. As lie left the shop, Ko appeared to be in deep pam, according to testimony later given by Shen T'i-jen, Ko's step-father. ${ }^{125}$ Similar inforination about Ko's condition on that morning caine from testimony taken from the ti-pao (local constable) Wang

lies began seriously to study the Classics and other literature. At no point in the late Ch'ing, however, did the extension of literacy encompass poor peasant women such as Hsiao-pai-ts'ai. E. Rawski, Education and Popular Literacy in Ch'ing China 6.8 (1979).

120. IMPORTANT Policies, supra note 32, at 2:3a.

121. Id.

122. Shen Pao, Mar. 29, 1876.

123. IMPORTANT Policies, supra note 32, at 2:3a.

124. Id.

125. Id 
$\operatorname{Lin}^{126}$ and a bystander, both of whom saw Ko vomit on the way home, and from Wang Hsim-p'ei's wife, who was startled to see him stagger into the house shortly before noon.

After arriving home, Ko took to his bed and then ordered Hsiaopai-ts'ai to take 1000 cash to her father so that he might purchase dried longans, chicken-foot soup, and other inedicinal substances. ${ }^{127}$ However, before Hsiao-pai-ts'ai could leave the house, Ko began to vomit and gasp for breath. Then, suddenly, he lapsed into semi-consciousness and began to emit a white phlegm-like fluid from his mouth. ${ }^{128}$ Hsiao-pai-ts'ai was horrified by this sight and let out a loud cry that brought Wang Hsin-p'ei and his wife running. Sensing that Ko's condition was serious, Wang immediately sent for Ko's mother, Hsiao-paits'ai's mother, and a neighborhood physician. ${ }^{129}$ Despite their efforts, Ko failed to regain consciousness and died early that evening. ${ }^{130}$

Although Ko's mother, Mrs. Shen, initially assumed that her son's death had been caused by illness, she soon came to suspect foul play. Accounts of the case differ markedly in their descriptions of what aroused her suspicion. One source ${ }^{131}$ indicates that Ko's body began to decompose at an inordinately rapid rate, thus leading his inother to enlist the aid of the local constable im preparing a petition asking the magistrate to help clarify the cause of her son's death. ${ }^{132}$ Others ${ }^{133}$ imphicate Magistrate Liu's son as having implanted in the minds of Mrs. Shen and the magistrate the idea that Ko had been poisoned. Still another ${ }^{134}$ remarks that a hitigation trickster ${ }^{135}$ named Wang conspired with a local physician to persuade Ko's mother to complain to the magistrate in the hope that they might extract large fees from her. And one

126. According to Ch'u T'ung-tsu, within each neighborhood, the ti-pao essentially "served as the messenger to the inagistrate," reporting local disputes and grievances. CH'Ü T'UNG-TSU, LoCaL Government, supra note 16, at 3-4. The position of ti-pao is also discussed in 1 Chang IVejen, Legal SyStem, supra note 30, at 154-55.

127. IMPORTANt Policles, supra note 32, at 2:3a. Although the value of copper cash varied according to time and place, in Chekiang during the period in question, 1000 cash would not have been an insubstantial sum for someone of Ko's position, as it was roughly equivalent to a beancurd shop attendant's salary for six to ten weeks.

128. Id. at $2: 3 \mathrm{~b}$.

129. Peking Gazette, Apr. 12, 1877.

130. ImPORTANT POLICIES, supra note 32 , at $2: 36$.

131. Id.

132. As Ch'i T'ung-tsu reports, serious "[c]riminal cases, including homicide, robbery, theft, adultery, and kidnapping, could be reported to a magistrate at any time . . . " CH'Ü T'UNG-Tsu, LOCAL GOVERNMENT, supra note 16, at 119. The inagistrate was obligated to investigate all complaints of nurder and, indeed, could be punished for failure to apprehend the murderer within the deadlines set down by law. Id. at 121-22.

133. MiscellaneOUS ReCORDS, supra note 101, at 227-28; WRITINGS ON ADMINISTRATION, supra note 100 , at 4:727-28.

134. CASE HISTORY, supra note 100, at 357.

135. See supra note 76. 
further account ${ }^{136}$ suggests that it was not until she heard rumors on the day after her son's death about the extent of her daughter-im-law's involvement with Yang that she began to wonder.

Judging from the wording of Mrs. Shen's petition to Magistrate Liu and from the manner in which the Board of Punishments finally disposed of the case, the first of these accounts seems the most plausible. ${ }^{137}$ The version implicatimg Magistrate Liu's son is almost certainly false, as it was later established that he had left the district long before November 26, 1873. It is almost as unlikely that Mrs. Shen was prompted by a litigation trickster; first, because she was a poor woman unlikely to know of or be of much mterest to such a person, and second, because the Board of Punishments, which dispensed pumshments even to individuals having minor roles $\mathrm{m}$ the case, inakes no inention in its final verdict of any participation by the abhorred sung-kun. ${ }^{138}$ Finally, the lack of any reference in her petition to Yang, Hsiao-paits'ai, poison, or even neighborhood speculation casts soine doubt on the possibility that Mrs. Shen was notivated by local gossip.

\section{B. The Magisterial Investigation and Trial}

Magistrate Liu's first step, after receiving Mrs. Shen's petition on the morning of November 30,1873 , was to speak with the licentiate ${ }^{139}$ Ch'en Cliu-shan who reportedly was at the yamen to seek medical advice. ${ }^{140}$ One source suggests that $\mathrm{Ch}$ 'en and Yang were not on good terms, supposedly because their legal counseling had previously placed them in opposition. ${ }^{141}$ Although there is no confirmation of this antagonism, some accounts suggest that Ch'en emphasized neighborhood gossip suggesting that $\mathrm{Ko}$ had been poisoned and himting that Yang might be involved because he reportedly was already having an affair with Ko's wife. ${ }^{142}$

Accordingly, that afternoon Liu sent his watchman Shen Ts'aich'üan and his coroner Shen Hsiang to examine the body of the deceased. ${ }^{143}$ By the tinne these two inen arrived, the corpse had already

136. Shen Pao, May 22, 1876.

137. IMPORTANT POLICIES, supra note 32, at 2:4.

138. A New Supplement to THE CoNSPECTUS, supra note 32, at 15:5143-47.

139. As explained supra in note 108 , the term hicentiate was used to refer to holders of the first examination degree.

140. IMPORTANT Policies, supra note 32, at 2:3.

141. Chao K'e-chun, Injustice, supra note 33, at 18.

142. See, e.g., Shen Pao, May 22, 1876.

143. During the Ch'ing, magisterial staffs often included several hundred runners, of which watchmen were one type, Ch'Ü T'UNG-TSU, LOCAL GOVERNMENT, supra note 16, at 56-64, and from one to three corouers depending on the size of the district. I CHANG WEJEN, LEGAL SYSTEM, supra note 30, at 161 n.153; see infra note 308. Under Ch'ing law, Magistrate Liu should have personally supervised the examination of Ko's corpse. CH'ING CODE, supra note 76, § 412. Alison 
begun to blister and swell, particularly in the abdominal region. ${ }^{144}$ The torso had started to assume a greenish-black hue and its fingers and toes liad taken on an ashen-grey tinge. In addition, fluid had started to seep into the corpse's eyes and ears, further complicating the process of autopsy laid out in Hsi-yüan $l u,{ }^{145}$ the classic Chinese coroner's manual.

After a preliminary investigation of the corpse's exterior but before undertaking the required step of inserting silver probing needles into the corpse's cavities, the two functionaries began to argue about possible causes of deatll. ${ }^{146}$ Influenced by Cli'en Cliu-slian's statenient, the watchinan contended that the bloating and discoloration of the corpse indicated that Ko had been a victim of arsenic poisoning. The coroner, however, was not inclined to agree. As they quarreled about the cause of death, they forgot to cleanse their silver probing needles in the prescribed Gleditsia-based solution prior to inserting thein into Ko's throat. ${ }^{147}$ As a result, when the needles were extractcd, they were coated with a greenish-black fluid which, according to the $H$ si-yizan $l u$, suggested that death was not natural but liad been caused by the introduction of foreign substances.

In order to ascertain whether the foreign substance involved was a poison, the coroner then atteinpted to matcli the greenisli-black shading of the fluid covering the needles with the descriptions in the coroner's inanual of the colors that would appear liad a poison been ingested. Although the coroner was unable to make such a match and so determine that an identifiable poison had been used, he nonetheless concluded that the watchinan's original perception liad been correct. ${ }^{148}$ Therefore, together witl the watchinan, he prepared a report on his findings for the magistrate indicating that an autopsy had been per-

Conner suggests that "many [magistrates] left the exammation to the coroner, and filled out their reports according to his findings." A. Conner, supra note 29 , at 46.

144. IMPORTANT Policies, supra note 32, at 2:3b.

145. The Hsi-yitan lu (translated as The Washing Away of Wrongs by Brian McKnight) was compiled during the 13 th century to assist magistrates and coroners in their inspection of corpses. The Washing Away of Wrongs: Forensic Medicine in Thirteenth Century China (B. McKnight trans. \& annot. 1981) (an annotated translation of the Hsi-yrian lu); The Hsi-yrian Lu or Instructions to Coroners (H. Giles trans.), 3 CHINA REv. 30-38, 92-99, 159-72 (1874-75). Because, as Professor Ch'u T'ung-tsu notes, the $H$ si-yizan $l u$ was considered "the only authoritative guidebook," officials relied on it throughout the Ch'ing. CH'Ü T'UNG-TSU, LOCAL GOVERNMENT, supra note 16, at 120; see also I ChANG WEJEN, LEGAL SySTEM, supra note 30, at 166. The utilization of imperial Chinese forensic techniques, as described in the $H$ si-yizan $l u$ and other sources, is comprehensively discussed in Chung-Kuo Ku-TaI Ming-An ChIEn-yen Shu [The Method of INQuest in Capital Cases in Traditional ChINa] (Huang Wei-hsin ed. \& annot. 1981) (Taipei reprint).

146. A New Supplement to the Conspectus, supta note 32, at 15:5144; IMPORTANt Pol1CIES, supra note 32 , at $2: 4 \mathrm{a}$.

147. IMPORTANT POLICIES, supra note 32, at 2:4a.

148. Id. 
formed according to the standards set forth in the Hsi-yrian lu and that death had been caused by poisoning. ${ }^{149}$

Although the report the coroner delivered to Magistrate Liu failed to state the type of poison used and was later deemed by the Board of Punishments to be muddled and unclear, Liu accepted it at face value and immediately had Hsiao-pai-ts'ai brought to the yamen for interrogation. ${ }^{150}$ Confronted there with the news that her husband had been murdered, Hsiao-pai-ts'ai at first strenuously denied knowledge of that act. Liu, however, was not to be deterred, and ordered his staff to apply physical torture to her, pursuant to legal limits. ${ }^{151}$

Hsiao-pai-ts'ai stood by her initial denial for a considerable period of tinie, but the torture, which exceeded the legal norms, eventually broke her resistance. ${ }^{152}$ Having retracted her denial, Hsiao-pai-ts'ai stated that she had poisoned her husband by slipping arsenic into his food. ${ }^{153}$ She quickly added, however, that the poisoning had not been her idea and had been carried out at the urging of another individual. After hesitating as to the identity of the instigator and then finding herself subject to further torture, Hsiao-pai-ts'ai at last declared that the person responsible for plotting the death of her husband was the chiijen, Yang Nai-wu. ${ }^{154}$ Yang, she hastily explained, had been her lover ever since the tinie that she and her husband had rented a room in his house. His concern about her husband's suspicions and his anger at the beating her husband had given her had finally led him to decide to have her poison Ko. She had originally opposed the idea but Ko's continued harassment and Yang's promise to take her as his second wife after the deed was done had combined to persuade her to carry out his plan. Accordingly, on November 24, Yang had purchased the arsenic which she deposited in Ko's food on November 26.

Without bothering to seek evidence corroborating Hsiao-pai-ts'ai's charges, Liu immediately had Yang arrested for instigating and directing the murder of Ko P'in-lien. ${ }^{155}$ Yang was indignant at being linked in any way witl the death of the lowly bean-curd shop attendant and demanded that he be freed. At that point, Liu had Hsiao-pai-ts'ai brouglit forward to repeat her story. Despite Yang's strenuous denial of

149. A New Supplement to the Conspectus, supra note 32, at 15:5144.

150. Id.

151. Id. Although they were often observed in the breach, the $\mathrm{Ch}$ 'ing did have precise rules regarding the application of torture. For a brief description, see T'AO HSI-SHENG, THE SYSTEM, supra note 30, at 34-36; A. Conner, supra note 29, at 119-67; infra notes 161, 292-94, 308 and accompanying text.

152. A New SUPPLEMENT to THE Conspectus, supra note 32, at 15:5144.

153. IMPORTANT POLICIES, supra note 32, at 2:4a.

154. A New Supplement to the Conspectus, supra note 32, at 15:5145.

155. IMPORTANT POLICles, supra note 32, at 2:4a. 
all she said, Liu had Yang placed in the yamen jail ${ }^{156}$ and on the first of December stripped him of his degree so that he could be placed on trial for Ko's murder. ${ }^{157}$

Informed of the details of the charge against Yang, his brother and brother-in-law went to the yamen to tell the magistrate that on the day Yang had allegedly handed Hsiao-pai-ts'ai the poison, he had in fact been with his wife's family in Nan-hsiang, a day's journey to the south of Yü-hang. Liu heard them out but decided that they had fabricated this alibi in order to protect their relative. ${ }^{158}$

During the next few days, Liu contimued to take testimony from Wang Hsin-p'ei, Mrs. Shen's husband Shen T'i-jen, and others acquainted with the accused and the deceased. Although this later testimony was vague and contained no concrete evidence further implicating the accused, in early December Liu formally decided that Yang was guilty of the offenses of adultery and instigating a inurder and that Hsiao-pai-ts'ai was guilty of the offenses of adultery and murdering a superior relation. ${ }^{159}$ Magistrates were prohibited by law, however, from passing more than provisional sentences in cases involving crimes carrying punishments heavier than bambooing. ${ }^{160}$ Moreover, proper judicial practice inandated that a suspect acknowledge his guilt before final judgment could be rendered. ${ }^{161}$ Therefore, after reaching his decision, Liu began to prepare a report to be sent along with the two prisoners to the next level of the legal system-the Hangchow prefecture. In the first part of his report, Liu restated the findings of his coroner, set forth Hsiao-pai-ts'ai's confession and the other testimony given, and described the confrontation between her and Yang. In the remainder of his report, Liu recommended that for their crime, she should be shiced to death (ling-ch'ih) and he beheaded (hsiao-shou). ${ }^{162}$ Accord-

156. Chao Ke-ch'ün, Injustice, supra note 33, at 18.

157. IMPORTANT POLICIES, supra note 32, at 2:4a. Although non-office holding degree recipients were not exempt froin either arrest or punishment, the law did provide thein with the opportunity to "redeem" most sentences with payments. By first stripping Yang of his degrees, Magistrate Liu effectively denied that privilege to Yang. See infra text accompanying note 262.

158. ImPORTANT POLICIES, supra note 32, at 2:4a-5b.

159. Id.

160. After reaching a provisional sentence (ni), the magistrate was required to send (chiehshen or chao-chieh) the accused and all necessary documents to the prefect. Shiga, Criminal Procedure (I), supra note 30 , at 17.

161. Although some authorities have stated that Ch'ing law required confessions from defendants, J. Cohen, Criminal Process, supra note 11, at 6, the better view is that there was no formal Iegal requirement. From T'ang times (618-907 A.D.) onward, if not earher, however, such acknowledgeinents apparently were considered essential coinponents of criminal trials. Shiga, Criminal Procedure (II), supra note 30, at 120-22; A. Coumer, supra note 29, at 190-204.

162. Because of the Confucian admonition that it was unfilial to die lacking any part of the body with which one had been born, death by slicing and beheading (after which the head was to be exposed) were considered, in that order, the two most severe punishments available under the Ch'ing Code and were therefore to be prescribcd only for the most heinous crimes. 
ingly, on December 9, 1873, Yang Nai-wu, Hsiao-pai-ts'ai, and Magistrate Liu's report were sent to the Hangchow prefect $\mathrm{Ch}^{\prime}$ en $\mathrm{Lu}$.

\section{A Prefectural Rehearing}

Notwithstanding the dubious quality of the Yu-hang coroner's findings and the fact that Yang had persistently refused to confess, the Hangchow Prefect Cl'en Lu chose to act upon, rather than question, the basic premises of Liu's report. Instead of carrying out a fresh, comprehensive investigation of the facts of the case as was required by law, ${ }^{163} \mathrm{Ch}^{\prime}$ en satisfied himself with ordering Mrs. Shen to coine to Hangchow and make a statement about her son's death. ${ }^{164}$ By this time, feeling that Hsiao-pai-ts'ai and Yang Nai-wu probably had been involved in Ko's death and being eager to seek revenge, Ko's mother decided to "elaborate" on the facts contained in the petition that she had initially subinitted. ${ }^{165}$ Accordingly, at Hangchow she declared that Hsiao-pai-ts'ai and Yang Nai-wu had committed adultery and generally had behaved in such a way that it was certain that they were responsible for her son's death by poisoning. ${ }^{166}$

His initial inipressions buttressed by Mrs. Shen's testiniony, Ch'en Lu summoned Hsiao-pai-ts'ai and Yang Nai-wu for interrogation. Hsiao-pai-ts'ai readily repeated her confession. Yang, however, persisted in proclaiming his innocence, whereupon Ch'en ordered his staff to torture Yang. ${ }^{167}$ After applying a variety of tortures, mcluding beating, stretching, and pressimg (between two wooden boards), Ch'en's staff finally succeeded in extracting a stateinent from Yang to the effect that he was responsible for imstigating and directing the murder of Ko P'in-lien. ${ }^{168}$ When pressured to supply further details, Yang stated that while on the road hoine from Nan-hsiang on November 22 he had stopped at a sinall pharinacy run by a man nained Ch'ien Pao-sheng. ${ }^{169}$ There, on the pretext of needing something with which to eliminate rats, he had purchased arsenic. Later, continued Yang, he had supplied this poison to Hsiao-pai-ts'ai and had imstructed her how to place it in Ko's food.

Having elicited the source of the poison, on December 16, Prefect Ch'en directed Magistrate Liu to find the druggist Ch'ien Pao-sheng.

163. Prefects and higher level officials receiving cases carrying provisional sentences were expected to carry out vigorous examinations of the relevant individuals and documents. Shiga, Criminal Procedure (I), supra note 30, at 17.

164. A New Supplement to the Conspectus, supra note 32, at 15:5145.

165. Id. at 15:5145; see also IMPORTANr Policies, supra note 32, at 2:4.

166. A New SUPPLEMENT TO THE CONSPECTUS, supra note 32, at 15:5144-46.

167. IMPORTANT Policies, supra note 32, at 2:4a.

168. Id.

169. Id. 
Liu then ordered the District Sub-Director of Studies Chang Chün to find and interrogate the druggist implicated by Yang. ${ }^{170}$ Chang found a druggist meeting Yang's description, but named Ch'ien T'an. Ch'ien, however, insisted that he was not the individual being sought, that his personal name had never been Pao-sheng, and that he had never transacted business with Yang Nai-wu. ${ }^{171}$ At this point, Ch'ien's younger brother prevailed upon the licentiate Ch'en Chu-shan to intervene. ${ }^{172}$ Ch'en visited the pharmacist in the yamen and was there able to persuade him that it would be in his best interests to cooperate. Specifically, Ch'en was able to badger the druggist into giving a statement conforming with Yang Nai-wu's assertions by suggesting that Ch'ien would receive no inore than a nominal punishment if he confessed and by himting that inore might await him if he refused to cooperate. ${ }^{173}$

It is unclear whether Ch'en Chu-shan informed Magistrate Liu of the extent to which he had badgered Ch'ien T'an, but after personally interviewing Ch'ien, $\mathrm{Liu}$ seems to have become wary of what he might say. ${ }^{174}$ Instead of following the standard procedure of sending the accusmg witness to the prefecture, however, he merely forwarded a transcript of Ch'ien's testimony. Prefect Ch'en, in turn, accepted the transcript and did not pursue the matter further, although under Ch'ing law he should have spoken directly with the druggist. ${ }^{175}$ Instead, on the basis of the original report of Magistrate Liu, the transcript of Ch'ien T'an's testimony, the statement given by Mrs. Shen, and the confessions of the two prisoners (with regard to which he made no mention of torture), Prefect Ch'en drew up a report in which he endorsed Liu's origmal recommendations. ${ }^{176}$

\section{The Case Moves to the Provincial Level}

Consistent with the requirements of Ch'ing law, ${ }^{177}$ in late December Ch'en $\mathrm{Lu}$ forwarded his report, the other documents pertaiming to the case, and the two prisoners to the provincial Judicial Commissioner K'uai Ho-sun. ${ }^{178}$ After scrutinizing the written materials he had received on December 25 and noting his approval of Magistrate Liu's

170. A New Supplement to THE Conspectus, supra note 32, at 15:5144. As District SubDirector of Studies, Chang's chief responsibility consisted of overseeing candidates for the imperial examinations.

171. Chao K'e-chun, Injustice, supra note 33 , at 18.

172. IMPORTANT POLICIES, supra note 32, at 2:4a.

173. Id.

174. Chao K'e-chun, Injustice, supra note 33, at 18.

175. Shiga, Criminal Procedure (I), supra note 30, at 17.

176. A New SUPPLEMENT to THE Conspectus, supra note 32, at 15:5146.

177. Shiga, Criminal Procedure (I), supra note 30, at 17-25.

178. The judicial commissioner (an-ch'a shih or nieh-ssu) was in charge of judicial affairs within the province. This position was felt to be one of considerable importance and was often 
original recommendations, $\mathrm{K}^{\prime}$ uai sent the case along to the Chekiang Governor Yang Ch'ang-chün. ${ }^{179}$ Governor Yang made a preliminary review of the comments and then, as was standard procedure, dispatched an expectant magistrate ${ }^{180}$ to Yü-hang to conduct a secret investigation into the facts of the case. Wishing to avoid antagonizing Governor Yang, the expectant magistrate Cheng Hsi-kao conducted only the most superficial of inquiries, from which he composed a report confirming in all major aspects those submitted by Liu and Ch'en. ${ }^{181}$ Reassured by Cheng's report, Governor Yang decided to dispense with any questioning of the two prisoners and to commence work immediately upon the report to the Board of Punishinents which the Ch'ing Code required in all cases carrying the death sentence. ${ }^{182}$ While noting a few mimor factual discrepancies between the reports submitted by Liu and Ch'en, the Governor declared that the Yü-hang coroner's findings, the confessions, and the statements of Mrs. Shen and Ch'ien T'an taken together showed that Hsiao-pai-ts'ai and Yang Nai-wu were indeed guilty ${ }^{183} \mathrm{He}$ therefore endorsed the sentences suggested by Magistrate Liu. As a final touch, the Governor proudly drew the Board's attention to the fact that his subordinates had solved this inajor case without resort to excessive torture.

Under Ch'ing law, an individual feeling that he had received less than a fair hearing at the district, prefectural, or provincial levels could

filled by officials with particular skill or experience in legal matters. The position's responsibilities are described im 1 ChaNg WeJEN, Legal SySTEM, supra note 30, at 175.

179. Yang Ch'ang-chun was a native of Hunan. He rose to prominence through his involvement in the Hung-yang Army's campaigns agaimst the T'ai-p'ing rebels and his links with the powerful Tso Tsung-t'ang. In 1874, largely with the assistance of Tso, Yang was named Governor of Chekiang. Chinese BIographical Dictionary 894 (H. Giles comp. 1898) [hereinafter cited as H. Giles, Biographical Dictionary]; Chung-Kuo Jen-ming TA Tse-tien [Chinese BioGRAPHICAL DICTIONARY] 1266 (Fang I comp. 1958) (Taipei reprint) [hereinafter cited as FANG I, Chinese Biographical Dictionary].

180. A New Supplement to THE CoNSPECTus, supra note 32, at 15:5146. During the Ch'ing, provincial governors generally had snall official staffs. Successful exainination candidates awaiting permanent assignment (known as "expectant officials") were one source of manpower, especially in judicial matters. Having passed the chin-shih examination five to ten years earlier and spent the intervening period in minor positions in the capital, these individuals were sent by the Board of Punishments to a province to await assignment by the provincial governor to a particular district. Shiga, Criminal Procedure (I), supra note 30, at 13-14. As happened in the case of Yang Nai-wu, the effectiveness of these officials may have been undercut by their inexperience, lack of regular position, and fear of offending officials already resident in the province where they inight well spend considerable time.

181. A New Supplement to the CONSPECTUS, suprá note 32, at 15:5144-46.

182. HSÜEH YÜN-ShENG, TU-LI Ts'UN-I [ThOUghtS ABOUT UNCERTAIN MATters Gleaned While Perusing the Substatutes] 411:00 (Huang Tsing-hua ed. 1970) (Taipei reprimt) [hereinafter cited as HsüEh YÜN-SHENG, THOUGHTS ABOUT UNCERTAIN MATTERs]. This and all subsequent references to Thoughts About Uncertain Matters follow Hsteh's fornnat for discussing the statutes and substatutes of the Ch'ing Code.

183. A New SUPplement to THE CONSPECtus, supra note 32, at 15:5144-46. 
send a special petition (in a procedure known as ching-k'ung or capital appeal) $^{184}$ to the Censorate, the Board of Punishments, or the ComInandant of Gendarmerie ${ }^{185}$ in Peking requesting a reexamination of his case. During May of 1874, Yang conıposed a petition to be dehvered by his nother to the Censorate. ${ }^{186}$ In it he first repudiated his confession, statimg that it had been extracted by excessive torture, and then histed three reasons why his case should be fully retried. ${ }^{187}$ The first, he declared, was that Magistrate Liu's son, Liu Tzu-han, and a Yü-hang resident named Ho Ch'un-fang had been sexually involved with Hsiao-pai-ts'ai. They should therefore be interrogated, as should the yamen runner Yüan Te, who had sought to extort nioney from the deceased, in order to determine whether they had influenced Hsiaopai-ts'ai to nanie Yang in her confession. The case should also be reinvestigated, said Yang, because of the possibility that Ko may have met with violence from Shen T'i-jen, the man Ko's widowed nother had recently married. ${ }^{188}$ Shen, explained Yang, was an ill-tempered individual who had often quarreled with Ko in the past. Shen's violent nature, alleged Yang, was borne out by the fact that a close relative of his had died under inysterious circumstances not long before Ko's death. A third reason, wrote Yang Nai-wu, lay in the contradictions and other errors contaimed in the statenents given by Hsiao-pai-ts'ai and Ch'ien Pao-sheng.

The Censorate did not grant Yang's request for a complete new trial. ${ }^{189}$ However, as was standard procedure at that time, the Cen-

184. In addition to the obligatory review of cases in which a magistrate had recommended a serious sentence, Ch'mg law at the time of Yang's petitions to the capital enabled individuals to appeal cases, provided that (1) the case was completed at the level of the district magistrate, (2) the case was appealed to a provincial official with responsibility for the official whose decision was being challenged or to specified governmental bodies in Peking, see infra text accompanying note 185, and (3) the probletn prompting the appeal was a serious one. Shiga, Criminal Procedure (II), supra note 30, at 30-38; T'AO Hsl-SHENG, THE SYSTEM, supra note 30, at 56-60. The term shang$k^{\prime}$ 'ung was used to refer to such appeals generally, while ching-k'ung [capital appeal] was used to refer to appeals that were made directly to officials in Peking. A history of the ching-k'ung can be found in CH'IN-TING T'AI-KUEI [IMPERIALLY ESTABLISHED REgulationS FOR THE CENSORATE] (1892) [hereinafter cited as CENSORATE Regulations]. This procedure is discussed further infra in notes 186, 297-301, 315-32 and accompanying text. See also Ocko, supra note 29.

185. The Commandant of Gendarmerie (pu-chtin t'ung-ling) was charged, inter alia, with responsibility for much of the police work im Peking. Shiga, Criminal Procedure (I), supra note 30, at 23.

186. Actually, Yang's sister dehivered the petition for him. IMPORTANT POLICIEs, supra note 32, at 2:5a. The Ch'ing Code provided that such appeals could be made on behalf of a defendant by close relations, such as a parent or spouse. Shiga, Criminal Procedure (I), supra note 30, at 30 31. Chang Wejen further suggests that sung-kun often were involved in the ching-k'ung procedure. 1 Chang Wejen, Legal. SySTEM, supra note 30, at 224 n.I06. Such appeals could also be made by or on behalf of persons whose complaints initiated criminal cases (such as Mrs. Shen).

187. ImPORTANT Policies, supra note 32, at 2:5a.

188. Chao K'e-chun, Injustice, supra note 33 , at 19.

189. IMPORTANT POLICIES, supra note 32 , at 2:5a. 
sorate referred the case back to Chekiang provincial Governor Yang Ch'ang-chün for further consideration. ${ }^{190}$ To elicit information about the charges raised by Yang Nai-wu in his petition, the Governor referred the case back to the officials beneath him who earlier had investigated it. ${ }^{191}$ Prefect $\mathrm{Ch}^{\prime}$ 'en $\mathrm{Lu}$ questioned Shen T'i-jen and the neighborhood official Wang Lin. Both denied Yang Nai-wu's charges, leading Prefect Ch'en to reaffirm his earlier findings. This prompted Governor Yang subsequently to inform the Censorate that a second look at the case had failed to turn up evidence inconsistent with the initial verdict.

Despondent over the failure of his capital appeal, Yang resolved to appeal at the provincial level. In August of 1874, he arranged for his wife to deliver a petition to the Chekiang Judicial Commissioner K'uai Ho-sun ${ }^{192}$ asking for a reinvestigation of his case. When that request was rejected, Yang decided to undertake a second petition to Peking. The first petition, he reasoned, had failed because it was not detailed enough. ${ }^{193}$ In the second, which was delivered by his wife to the Cominandant of Gendarmerie in October, he took pains to elaborate further the reasons advanced in the first and to set forth four additional factors which he felt indicated the nced for a new trial. ${ }^{194}$ Briefly, the new factors were the inconsistencies in Mrs. Shen's two statenents, the failure of the Hangchow Prefect to provide him with an opportunity to confront the druggist Cl''ien, Yang's presence in Nan-hsiang on the day he allegedly handed Hsiao-pai-ts'ai the poison, and the seeming willingness of higher officials hearing his case to cover up errors made at the district and prefectural level.

After weighing Yang's second capital petition, the Commandant of Gendarnerie in Peking forwarded it to the Throne, ${ }^{195}$ which in-

190. Prior to 1882, a body receiving such a petition could either refer it back to the governor of the province from which it came (tzu-hui) or submit it to the emperor (chti-tsou). Shiga, Crimtnal Procedure (I), supra note 30, at 33-34.

191. IMPORTANT Policies, supra note 32, at 2:5a.

192. Id.

193. Shen Pao, Dec. 7, 1874.

194. IMPORTANt Policies, supra note 32, at 2:5b; Shen Pao, Dec. 7, 1874; id., Dec. 8, 1874.

195. On January 12, 1875, the T'ung-chih Eınperor died childless. In an effort to insure her continued access to power, his Einpress Hsiao-ch'in broke the laws of inperial succession and named her three-year-old cousin Tsai-t'ien as the Emperor. Hsiao-ch'in, who is now nnore commonly referred to as the Einpress Dowager Tz'u-hsi, also assumed the position of regent, along with the Empress Hsiao-chen. Eminent Chinese of the Ch'INg Period 295-300, 731-33 (A. Hummel ed. 1964) (Taipei reprint) [hereinafter cited as EMINENT Chinese]. Because of the tender age of the new Emperor, who took the reign name Kuang-hsu, and due to the uncertainty of both Western and Chinese scholars about the manner in which decisions were unade in the court during the first years of his reign, in the remainder of this Article the term "the Throne" will be used when reference is made to decisions taken in the name of the Kuang-hsu Emperor while he was still a young child. 
structed Governor Yang Ch'ang-chün once again to reconsider the case. This time Governor Yang appointed a five-man committee to investigate the charges made by Yang in his second capital petition. ${ }^{196}$ The committee was headed by Hsi Kuang, the Prefect of Hu-chou, which bordered on Hangchow, and also mcluded the Shao-hsing Prefect Kung Chia-chün, the expectant Chin-hua Prefect Sun Hsiang-fu, the Fu-yang Magistrate $\mathrm{Hsui} \mathrm{Chia-te,} \mathrm{and} \mathrm{the} \mathrm{Huang-yen} \mathrm{Magistrate}$ Ch'en Pao-shan. ${ }^{197}$ During the committee's investigation, which was conducted largely behind closed doors and of which no official record seems to exist, Yang Nai-wu and Hsiao-pai-ts'ai both repudiated their confessions. ${ }^{198}$ Accordingly, this group of officials inforined Governor Yang that they were unable to reach any conclusion. ${ }^{199}$ Construing this to be an affirmation of his previous conclusion, Governor Yang submitted a memorial to the Throne ${ }^{200}$ stating that his second reinvestigation of the case had uncovered no evidence warranting a reversal of the initial verdict. ${ }^{201}$

\section{E. The Case Assumes Broader Political Dimensions}

Although Yang Nai-wu's second petition failed to produce a reversal of the verdict against him, it did generate extensive publicity about the case. In Shanghai, the fiedgling newspaper Shen Pao, which had earher run brief and intermittent articles about the case, began to devote more space to Yang's situation. The decision of the commission led by the Hu-chou Prefect Hsi Kuang to hold its sessions in camera stirred the paper to ask sharply whether the officials hearing the case were trying to withhold inforination from the defendants, the public, or their superiors. ${ }^{202}$ In particular, the Shen Pao also wanted to know why the various officials hearing the case had refused to allow Yang to confront the druggist accusing him of having purchased poison. ${ }^{203}$ Meanwhile, in Peking, the case and the manner in which it had been handled by the bureaucracy had become a source of concern to certain

196. IMPORTANT Policies, supra note 32, at 2:5a.

197. A New Supplement to THE CONSPECTUS, supra note 32, at 15:5143-47.

198. IMPORTANT Policies, supra note 32, at 2:5a.

199. Id.

200. Chao K'e-chun, Injustice, supra note 33, at 20.

201. Id.

202. Shen Pao, Apr. 12, 1875; id., Apr. 13, 1875. The law did not mandate that trials be held in public. It was, however, common practice for magistrates to allow the public to attend trials. CH'Ü T'UNG-TSU, LOCAL GOVERNMENT, supra note 16, at 125.

203. Shen Pao, Apr. 12, 1875. Ch'ing law did not require that the defendant have an opportunity to confront his accuser although, iromically, it did require that multiple defendants be confronted with each other (presumably so the magistrate could observe their imteraction and compare their stories). CH'ING CODE, supra note 76, § 405 . Alison Conner indicates that although not required by law, many Chinese nagistrates chose to confront defendants with their accusers "m order to compare their demeanor and testimony." A. Conner, supra note 29, at 74-76. 
officials. Thus, when Governor Yang concluded his second reinvestigation by endorsing the original verdict, the censor Wang Shu-jui submitted a memorial ${ }^{204}$ asking the Throne to remove the case from the Chekiang governor's jurisdiction and place it in the hands of an imperially appointed special commissioner. ${ }^{205}$

On May 28, 1875, the Throne responded to Wang Shu-jui's memorial by appointing a special investigatimg committee headed by the Chekiang province Literary Chancellor $\mathrm{Hu}$ Jui-lan and including the Ning-po Prefect Pien Pao-hsien, the Chia-hsing Magistrate Lo Tzu-sen, and the expectant magistrates $\mathrm{Ku}$ Te-heng and Kung Shih-t'ung. ${ }^{206}$ $\mathrm{Hu}$, continued the Throne, should be mindful in carrying out this investigation that his Einperor desired that all aspects of the case be searched out and thoroughly considered. To accomplish this task, $\mathrm{Hu}$ and his colleagues gathered in Hangchow on July 21, 1875, and began an intensive review of the documentary materials related to the case. ${ }^{207}$

In the late summer of 1875 , Hu's committee summoned Hsiao-paits'ai and Yang Nai-wu for interrogation. Hsiao-pai-ts'ai was apparently intimidated by this new tribunal and was unwilling to repudiate the confession she had originally given to Magistrate Liu. ${ }^{208}$ Yang, however, stuck by the repudiation he had made earher. According to the Shen Pao's account of this session, when Hu asked him why he had chosen to repudiate his confession, Yang made an effort to describe the major errors that he felt had been made in his case. ${ }^{209}$ However, contimued the report, when $\mathrm{Hu}$ responded to these answers of Yang's with criticism and sarcasm, Yang exploded. He first declared bitterly that the torture inflicted upon him by the Hangchow Prefect Ch'en Lu's staff was responsible for his confession and then angrily denounced the officials who had heard his case for covering up the errors of their predecessors. Notwithstanding these strong words, Yang failed to persuade $\mathrm{Hu}$ of his innocence. ${ }^{210}$

By early November $1875, \mathrm{Hu}$ and his colleagues had concluded

204. TUNG-HUA Records, supra note 32, at 365-66. This same memorial is also reproduced in the Kiangsi Nieh-ssu Ting-li Hui-pien [The Established Regulations of the Kiangsi Provincial Judicial Commissioner's Office], a compendinm of rules, regulations, and other information pertaining to national administrative affairs. See Chen, Provincial Documents of Laws and Regulations in the Ch'ing Period, in 3 CH'ING-SHIH WEN-TI No. 6, at 28 (Dec. 1976).

205. Chao K'e-chü, Injustice, supra note 33, at 20.

206. See TUNG-HUA RECORDS, supra note 32, at 366 for the names of the five members of this committee; see also Chao K'e-chun, Injustice, supra note 33, at 20. By the time the case of Yang Nai-wu and Hsiao-pai-ts'ai arose, special commissioners were assigned only in extraordimary situations. Shiga, Criminal Procedure (I), supra note 30, at 33-34.

207. Chao K'e-chun, Injustice, supra note 33, at 20.

208. Shen Pao, Dec. 17, 1875.

209. Id.

210. Id. 
their investigation. The findings of Magistrate Liu, memorialized $\mathrm{Hu},{ }^{21}$ were essentially correct, save for a few minor factual discrepancies pertaining to matters such as the day upon which the poison was purchased. The charges and claims made by Yang Nai-wu in his two petitions, continued the memorial, could easily be dismissed. Magistrate Liu's son was named Liu Hai-sheng, not Liu Tzu-han as stated by Yang, and, inoreover, he was a fifty-year-old man who had left Yu-hang for his home soine months before the murder occurred. Ho Ch'un-fang and Yüan Te clearly had not had any involvement with Hsiao-pai-ts'ai. Mrs. Shen had not mentioned Yang and Hsiao-paits'ai in her imitial petition because at that time she feared retribution from her son's killers. Yang's ahibi that he had been in Nan-hsiang on November 24, 1873 was not credible since only his close relatives could corroborate it. The animosity which Yang said characterized the relationship between Shen T'i-jen and Ko P'in-lien simply did not exist. Shen and Ko had gotten along well and the death of Shen's relative that Yang had spoken of in his first petition was the result not of foul play, but of illness. In hight of all this, concluded $\mathrm{Hu}$, the Throne should adopt the reconimendations inade by Magistrate Liu in his original report. 212

The Throne was pleased to receive Hu Jui-lan's report, for it seemed that on the basis of this careful investigation, a rather long and bothersome murder case could at last be brought to an appropriate end. Therefore, the Throne instructed the Board of Punishments to conclude the case in accordance with Hu's findings. Not all inembers of the imperial bureaucracy, however, shared this view of Hu's work. On November 15,1875 , the censor Pien Pao-ch'üan submitted a strongly worded memorial to the Throne attacking the report and asking that the Throne order the Board of Punishments to try the case anew in Peking. ${ }^{213}$ It had long been known in certain official circles, stated Pien, that Hu Jui-lan was a close friend of the Chekiang Governor Yang Ch'ang-chün. Nonetheless, nembers of those circles had refrained from protestimg Hu's appointinent as special commissioner in the hope that he imght place duty above friendship. Now it was evident that he had not: Hu's report had glossed over the inconsistencies in the record and unreservedly endorsed the findings of all Chekiang officials involved in the case. ${ }^{214}$

Yet, continued Pien, the problems manifested by this case went

211. Ta-ch'ing Te-tsung Ching Huang-ti Shih lu [The Veritable Records of the KUANG-HSÜ EMPEROR] 19:166-70 (Taipei reprint 1964).

212. Id.

213. TUNG-HUA RECORDS, supra note 32, at 151.

214. Peking Gazette, Dec. 2, 1875. 
beyond those posed by the friendship of $\mathrm{Hu}$ Jui-lan and Yang Ch'angchun. In recent years, even the most independent of special commissioners had failed to find fault with the work of provimcial officials. This did not result from the uniform excellence of provincial administration, but rather had two causes: provincial officials had greater power than middle-level representatives of the central government and special commissioners, who generally had small investigative staffs, had to rely heavily upon local officials. The present case should be brought to Peking, Pien concluded, not only to resolve its apparent imconsistencies, but also to show provincial officials that there were bounds to their authority. ${ }^{215}$

The Throne did not issue an immediate response to Pien's inemorial, but instead sent it to the Board of Punishments with orders to devise recommendations by Noveinber $23 .^{216}$ One of the first high-level Board officials to act upon this edict was the young Emperor's tutor Weng T'ung-ho, who had taken up the post of Junior Vice-President of the Board only during the previous August. ${ }^{217}$ Weng launched into the inatter of Yang Nai-wu by ordering the Board archivist to supply him with a coinplete copy of the Board's file on this case. ${ }^{218}$ To his surprise, the Board's archivist was hesitant to fulfill this order and finally did so only after receiving a rebuke. According to his diary, once Weng had a chance to study the file, he began to suspect that there might be a good reason for the archivist's hesitancy. ${ }^{219}$ There was an odd discordance between the findings of fact im the case, which contained a number of unresolved discrepancies, and the air of total assurance that inarked the recommendations of the various officials who had heard it. In particular, Weng was puzzled by three unexplained iteins. ${ }^{220}$ The first two concerned Ko P'm-lien's financial resources. Ko had expended a considerable sum at the time he had inarried Hsiao-pai-ts'ai. Additionally, according to Magistrate Liu's report, both Hsiao-pai-ts'ai and Mrs. Shen had stated that as he lay ill, Ko P'in-lien had given Hsiao-pai-ts'ai more than 1000 cash for the purchase of medicines. How, Weng wondered, could a mere bean-curd shop attendant have accunnulated the suins that Ko apparently had? ${ }^{221}$ The other itein troubling Weng was the failure of Governor Yang Ch'ang-chün and Literary Chancellor

215. $I d$.

216. TUNG-HUA RECORDS, supra note 32, at 151.

217. Ch'ing-shih Lieh-Chuan [Biographies of Prominent Persons] 63:56-58 (Chunghua shu-chu comp. 1928); EMINENT CHINESE, supra note 195, at 860; WENG T'UNG-HO, DlARY, supra note 32 , at 825 .

218. WENG T'UNG-HO, DIARY, supra note 32, at 826 .

219. Id.

220. Id. at $826-27$.

221. Id. 
Hu Jui-lan both to investigate seriously Yang Nai-wu's charge that the magistrate's son was somehow improperly involved in the case and to interrogate Magistrate Liu directly.

The doubts Weng claimed had been generated by a reading of the case record were accentuated im the following days as Weng had conversations both with fellow officials of the Board and with private individuals. Weng's diary for the 17th, 18th, and 19th of November ${ }^{222}$ notes discussions on this matter with five individuals. These included fellow imperial tutor and Board of Punishments Vice-President Hsia T'ung-shan, ${ }^{223}$ the middle-level official Lin Kung-shu, who worked in the section of the Board responsible for criminal cases arising in Chekiang, a Yü-hang resident named Wu Chung-yü, and one of Weng's own nephews who had been following the case. The conversations with Hsia may have been influential in Weng's decision to involve himself more deeply in the case. Although Hsia clearly favored granting Yang a new trial, he may have feared that since he was a native of Yühang, he might be accused of local partisanship if he were too outspoken.

In any event, from November 17 to 25 , Weng, Hsia, and other major officials of the Board including the Chimese and Manchu Presidents ${ }^{224}$ Sang Ch'un-jung and Tsao-pao, the Manchu Vice-President Tsao-chi, and the Director of the Autumn Assizes ${ }^{225} \mathrm{Yu}$ Chuan met repeatedly to consider the recommendations that they were to send to the Throne. According to Weng's diary, he, Hsia, and Yu believed that the Board should urge the Throne to bring the case to Peking, while Sang and Tsao-pao felt that to do so would embarrass Magistrate Liu, Governor Yang, Literary Chancellor $\mathrm{Hu}$, and the other officials who had been involved with the case. ${ }^{226}$ Finally, with the imperial deadline alinost upon them, the Board officers agreed to send a memorial to the Throne that did not question the competence of any of the officials who had heard the case previously. Instead, it merely suggested that the case warranted a new trial in Peking because of the threat that the murder by an adulteress of her husband posed to the preservation of Confucian ethics. 227

222. Id.

223. EMINENT ChINESE, supra note 195 , at 860 .

224. Under the Ch'ing, two individuals-one Manchu and one Chinese-were appointed to each major position on the Six Boards.

225. The Director of the Autumn Assizes was an important Board official who assumed inajor responsibility for the review of capital cases arising from the provinces. H. BRUNNERT \& V. HAGELSTROM, supra note 28 , at 147-49.

226. WENG T'UNG-HO, DIARY, supra note 32 , at 826-27.

227. Id. at 827 . Unfortunately, Weng $T$ 'ung-ho does not seen to have played an active role in the case after this date, although he again makes mention of the case later in his diary. This is probably due to the fact that before the case again reached the Board of Punishinents (in 1877), 
Shortly after taking the Board's memorial under advisement, the Throne announced that it would not grant Pien Pao-ch'üan's request to have the case brought to Peking for a retrial. ${ }^{228}$ If a new trial before the Board of Punishments were granted in this instance, others might request retrials in the future, and the already busy Board might well be overburdened. ${ }^{229}$ In order to resolve the questions raised by Pien about Hu Jui-lan's investigation, however, the Throne ordered Hu to reconsider all materials pertaining to the case and then to memorialize the Throne as to the course of action it should pursue. ${ }^{230}$

Among those in the capital distressed by the Throne's decision to remand the case to Hu Jui-lan was a group of middle and upper middle-level officials from Chekiang. Eighteen of these imdividuals took the highly unusual step of involving themselves publicly im a legal matter entirely outside of their official responsibilities. ${ }^{231}$ Led by the Imperial Chancellery Secretary Wang Shu-p'ing, the Hanlin Academy Subreader Chung Po-sheng, and the Imperial Academy Tutor Wang Mingluan, they submitted a memorial to the Throne on December 19, 1875, asking that the case be brought to Peking for a retrial.

Their memorial was a masterpiece of mdirection. It indicated that they had initially feared that the abuses and errors that they found in the case of Yang Nai-wu were a product of Magistrate Liu Hsi-t'ung's desire either to extort money from Yang or to reap revenge for past troubles that Yang might have caused him. ${ }^{232}$ Closer investigation of the case materials in Peking as well as further conversations with imdividuals on the scene in Chekiang, however, had imdicated to them that Liu was wholly innocent of any conscious error and that the problems with the case could all be attributed to Hsiao-pai-ts'ai. In her effort to lighten the punishment that was sure to befall her for committing adultery and murdering her husband, that unconscionable woman had woven an intricate pattern of falsehoods that had both wrongly implicated Yang Nai-wu and led Liu Hsi-t'ung astray. Liu's determination to solve the hemous murder of Ko P'm-hien had led him to commit four basic errors. First, he had failed to consider the questions raised by Mrs. Shen's delay in reporting the death of her son and by the coroner's imprecision as to the type of poison used. Second, he had not taken seriously the exculpatory evidence provided by Yang's brother. Third,

Weng T'ung-ho resigned his position on that Board in order to accept the more important position of Vice-President of the Board of Revenue.

228. TUNG-HUA RECORDS, supra note 32, at 152-53.

229. Id.

230. Id.

231. Chao K'e-chun, Injustice, supra note 33, at 27. At least one other source suggests that 28 officials from Chekiang were involved. CASE HISTORY, supra note 100, at 359.

232. Shen Pao, Mar. 29, 1876. 
Liu had allowed his yamen staff to badger the druggist $\mathrm{Ch}^{\prime}$ 'ien $\mathrm{T}$ 'an into saying that he had sold Yang arseinc. And fourth, Liu had not bothered to point out how sharply Mrs. Shen's initial stateinents diverged froin her later testimony.

Due to his "inadvertent" errors, contmued the inemorial, Liu had produced a record for Prefect Ch'en Lu that made the case against Yang Nai-wu seem far more definite than it actually was. This, in turn, had stirred a zeal in Ch'en that led him to fall into a number of unfortunate, unintended errors. Prime among these were the application of excessive torture to Yang, the omission of a confrontation between Yang and the druggist, and the failure to spot inconsistencies between testimony given at the district level and that given at the prefectural level. Ch'en's innocent errors had, in turn, made it extremely difficult for higher officials to discern the case's true problems, with the result that at each appellate level the origmal judgment had been affirmed and the conduct of those lower level officials who had heard the case had been approved. The special iniperial commissioner Hu Jui-lan was a worthy official, as were all those who had earhier sat in judgment on this case; but because the problems were buried deeply in the record, even he had finally been led to ratify the initial verdict and absolve those below him of any wrongdoing. Surely, concluded the inemorial, if such worthy officials could be inisled by the case record, the only hope of finally reaching the truth of the matter lay in having the entire case brought to the Board of Punishinents in Peking for a retrial. ${ }^{233}$

The meinorial of Wang Shu-p'mg and his seventeen fellow officials from Chekiang succeeded where memorials from the Censorate and the Board of Punishınents had failed. Within days of its receipt, the Throne granted their request for a new trial before the Board of Punishinents. It was now apparent, declared the imperial edict, that nothing short of a full new trial in Peking would serve justice and set the public mind at ease. ${ }^{234}$ Governor Yang Ch'ang-chün was therefore ordered to arrange for the safe passage to Peking of the corpse of Ko P'in-hien and all relevant witnesses and documents. ${ }^{235}$

Although the imperial edict ordering the case brought to Peking did not counternand the earher one ordering $\mathrm{Hu}$ Jui-lan to reinvestigate the case, Hu was astute enough to recognize the import of this new order. In February of 1876 he subinitted a report to the Throne stating that upon reinvestigation, it was clear to him that the case was so coinplex that he was unable to dispose of it by himself. ${ }^{236}$ In hight of this,

233. Id.

234. TUNG-HUA RECORDS, supra note 32, at 165-66.

235. Id.

236. LI Tz'U-MING, DIARY, supra note 32, at 4498-99. 
he expressed hope that the Throne would either appoint additional special commissioners or arrange for representatives of the Board of Punishments to assist him in reaching a more definite conclusion. The Throne neither granted nor denied Hu's request, but simply ordered that his inemorials be inade part of the record of the case to be retried by the Board of Punishments. ${ }^{237}$

Rather than coinply immediately with the imperial order that all steps be taken to ensure the safe and expeditious transfer to Peking of the various individuals and naterials needed for the retrial, Governor Yang Ch'ang-chün responded by expressing his disapproval of the Throne's decision. ${ }^{238}$ Governor Yang was at least temporarily jolted out of this early resistance, however, by the death of the druggist Ch'ien T'an. Although Ch'ien's family reported that he had died of a sudden and mysterious illness, many in both Hangchow and Peking were inclined to believe that the pressures of his involvement with the law had driven Ch'ien to kill himself. ${ }^{239}$ The embarrassment that this apparent suicide caused Governor Yang (and perhaps not a few unsubtle himts fron1 Peking) stirred him to begim rounding up witnesses. Still, Governor Yang moved with deliberate slowness, taking such obstructionist steps as at first sending to Peking as witnesses many individuals who had no real knowledge of the case and later striving to prevent the attendance of two important witnesses. Notwithstandimg Governor Yang's maneuverings, the necessary mdividuals and documents were finally asseinbled in Peking by January of 1877.240

\section{F. The Case is Retried in Peking}

The retrial of the case of Yang Nai-wu and Hsiao-pai-ts'ai by the Board of Punishments commenced in the early morning hours of January 22, 1877 in the Hai-hui Teinple located near the Ch'ao-yang Gate to the city. ${ }^{241}$ Presiding officers fron the Board of Punishments began the session by asking Magistrate Liu a series of questions about the early history of the case. After completing their questioning, these officials called forward a specially chosen group of coroners headed by a venerated eighty-year-old forner Board coroner who had been suin-

237. Id.

238. TUNG-HUA RECORDS, supra note 32 , at 345-47.

239. LI T'ZU-MING, DiARY, supra note 32, at 4497-98; see also Shen Pao, Apr. 4, 1876. Suicide was a not altogether infrequent response of individuals who found themselves unwillingly enmeshed in legal matters. Hsieh \& Spence, Suicide and the Family in Pre-modern China, in Normal and AbNormal Behavior In Chinese Culture (A. Kleinman \& T. Lim eds. 1980).

240. IMPORTANT POLICles, supra note 32, at 2:5a; TUNG-HUA RECORDS, supra note 32, at 345 47.

241. Shen Pao, Mar. 7, 1877. 
moned froin retirement for this assignment. ${ }^{242}$ The presiding officials then ordered that the coffin of Ko P'in-lien be opened and the corpse placed on a special platform so that an examination could start.

The coroners decided, with the presiding officials' approval, that because the deceased's flesh had entirely decomposed during the years simce burial, they would attempt to ascertain the cause of death from the coloration of the bones. ${ }^{243}$ The coroners Sun I and Lien Shun then described to the assemblage the color of the various parts of the skeleton. ${ }^{244}$ According to their description, all parts bore a yellowish-white hue, save for the sternum which was a darker yellow shading almost into orange. Sun I and Lien Shun and the other coroners then huddled together to discuss the implications of their findings.

The coroners' dehiberations were brief, as all came quickly to the same conclusion. ${ }^{245}$ Ko P'in-hen, declared Sun I and Lien Shun as spokesmen for their colleagues, had died of illness. Both their own experience and the $H$ si-yüan $l u$ indicated that if poison had been involved in Ko's death, his jaws, sternum, fingers, and toes would now be a greenish-black and his skull a light red. Only Ko's sternum bore an unnatural color that might be even faintly suggestive of poisoning and, continued Sun and Lien, in all probability this shading had been produced by internal hemorrhaging caused by Ko's fatal illness. Given the present color of Ko's bones, they added, it seemed likely that the greenish-black fluid that the initial Yü-hang coroner found on his probing needles had resulted from his failure to wash the needles properly before inserting thein into the corpse.

After the coroners had stated their conclusions, the presiding offcials left their podium in order to verify the observations and results announced to them. ${ }^{246}$ Having satisfied themselves as to the accuracy of the coroners' findings, the Board officials then recalled Magistrate

242. CASE HISTORY, supra note 100 , at 359 . There is considerable discrepancy among available sources as to who presided over this session, how many other officials were in attendance, and what Magistrate Liu had to say in response to the initial inquiries made of him.

243. LI Tz'U-MING, DiARY, supra note 32, at 4921-23; Shen Pao, Mar. 7, 1877.

244. Shen Pao, Mar. 7, 1877.

245. Id., Apr. 5, 1877. Foreign (to China) forensic science-both contenporaneous with the case and more inodern-is inconclusive about whether arsenic (the poison allegedly used) would produce the effects noted by the coroners examining Ko P'in-lien's corpse in Peking. Many of Ko's symptoms in his last hours broadly fit those of arsenic poisoning, but they also broadly fit those of cholera. The mild discoloration of Ko's sternum noted by the coroners could, conceivably, have resulted froin the discoloration (usually of a reddish hue) of stoinach tissue often caused by arsenic poisoning. But the fact that Ko's body deconiposed with unusual rapidity suggests that arsenic poisoning may not have been the cause of death. Both 19th and 20th century toxicologists indicate that arsenic typically causes slow decomposition. H. Chambers, A MANUAL of Medi-

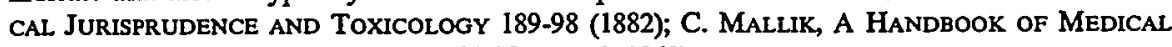
JURISPRUDENCE AND TOXICOLOGY 276-85 (1st ed. 1969).

246. Shen Pao, Mar. 7, 1877; id., Apr. 5, 1877. 
Liu in order to confront him with these results. Magistrate Liu had heard the coroners deliver their findings, and after first trying vainly to contest the issue, lie made a statement indicating his acceptance of both the Board coroners' lyypothesis as to the probable source of his own coroner's error and their conclusion as to the likely cause of Ko's death. ${ }^{247}$

With Liu's statement in hand, the presiding officials adjourned the retrial so that a report could be prepared for the Throne setting forth the new information which had been uncovered and making appropriate recommendations. According to the diary of Li Tz'u-ming, considerable debate ensued over two matters-the sentence that Liu should be given and the extent to whicl the retrial should be continued. ${ }^{248}$ With regard to the first, Board President Tsao-pao reportedly contended that in dealing with Liu, the Board should be mindful of the fact that he was a classmate (t'ung-nien) of the influential Grand Secretary Pao-yün. ${ }^{249}$ With regard to the second, Board President Sang Ch'un-jung argued that in deciding whether to inquire into the handling of the case above the prefectural level, the Board should not forget that Yang Ch'ang-cluun had received the Governorship of Chekiang because of his political connections. The report that finally emerged from these dehiberations was a compromise. It stated that the Board would conclude the retrial by looking in more depth at the manner in which the case had been handled at the district and prefectural levels and by recommending that pending further findings of error, Magistrate Liu should be stripped of his degrees and removed from office. $^{250}$

On January 29, the Throne accepted the Board's recommendations and urged it to press forward with its imvestigation. ${ }^{251}$ As had too often happened before in this case, lowever, the Throne's edict stirred strong reactions outside of the court. In this particular instance, the Throne's action prompted not one but two sharply worded responses. The first was delivered verbally during an imperial audience by Ting Pao-chen, the Acting Governor General of Szecliuan. ${ }^{252}$ It would be a grave mistake, lie said, to reverse the original verdict. Notwithstanding the $\mathrm{Hsi}_{\mathrm{s}}$ yüan $l u$, how could evidence derived from the bones of a man who had died many years earlier possibly be believed over the reasoned conclusions of skilled officials such as Liu Hsi-t'ung, Yang Ch'ang-chün, and

247. Shen Pao, Mar. 7, 1877; id., Apr. 5, 1877.

248. Li Tz'U-MING, DiARY, supra note 32, at 4941-42.

249. Id. The bond created among individuals who passed imperial examinations in the same year ( $t^{\prime}$ ung-nien) was an extraordinarily strong one that has no true analog in the West.

250. TUNG-HUA RECORDS, supra note 32, at 343.

251. Id.

252. LI Tz'U-MING, DIARY, supra note 32, at 4942. 
Hu Jui-lan?253 A recommendation such as that made by the Board in its latest memorial, continued Ting, could have come from the pen of the weak, senile Sang Ch'un-jung and so should not be given great weight. Magistrate Liu, concluded Ting, should be restored, and the origimal verdict ought to be reinstated.

The sharpness of Ting's statement was inore than matched by that of an unsolicited inemorial from the censor Wang Hsin. In no uncertam terms, Wang Hsin declared that although the errors of Magistrate Liu were reprehensible and sliould be punished, they were far more understandable than tliose of men suclı as Yang Ch'ang-chün and $\mathrm{Hu}$ Jui-lan, who had been entrusted with positions of major responsibility by the Throne. ${ }^{254}$ These high-level officials had failed to uncover the errors committed at the district and prefectural levels when they first reviewed the case. Moreover, they later had the effrontery to resist the Throne's clear desire to have a tliorougli reinvestigation. These men, continued Wang, were so audacious only because tlrey knew that the Kuang-lisui Emperor had not yet reached his maturity and therefore was aided in governing by the two Empress Dowagers. Because these officials souglit to take advantage of the Emperor and his regents, they ought to receive more severe punishments than those ordmarily given for similar errors. ${ }^{255}$

The infliction of especially severe sentences upon $\mathrm{Hu}$ Jui-lan and Yang Ch'ang-chün, continued Wang, would not only redress tle imjustices committed in the case of Yang Nai-wu, but would also serve to heigliten the impact the case liad already liad upon higli provincial officials and special imperial commissioners handling appeals in other cases. $^{256}$ In the past, charged Wang, such officials liad often sought to cover up the errors of their friends and subordinates; in fact, it liad been years since an appeal from the provinces had led to a inajor case being overturned in Peking. The salutary impact of the case of Yang Nai-wu could already be seen in the recent decision of a high-level Szechuan official to confess spontaneously that lie liad sliaded the truth in order to protect subordmate officials investigating an attack made on missionaries. It was most unlikely, stressed Wang, that this unusual confession would have been forthcoming but for the publicity created by the case of Yang Nai-wu. Therefore, he concluded, it was imperative that the Throne see that all culpable officials in the case of Yang Nai-wu receive stern sentences. ${ }^{257}$

\footnotetext{
253. Id.

254. Id. at 4975; TUNG-HUA RECORDS, supra note 32, at 345-47.

255. TUNG-HUA RECORDS, supra note 32, at 347.

256. Id. at 346 .

257. Id.
} 


\section{G. Punishment is Meted Out}

The Throne chose to adopt neither the suggestions made by Ting Pao-chen nor those made by Wang Hsin, but imstead declared that it would reserve decision until it had received a final report from the Board of Punishments setting forth its further findings and making appropriate recommendations. Taking less than ten days to respond, the Board recommended sentences for seventeen individuals and specifically absolved eight others of any blanne. ${ }^{258}$ In hight of the seriousness of the case, the Board took the additional and unusual step of suggesting that the imperial amnesty which had been declared when the Kuang-hsiu Emperor ascended the Throne ought not to apply to any of the offenses committed in this case. ${ }^{259}$

The most severe recommendation contained in the Board of Punishments' final report regarded Magistrate Liu Hsi-t'ung, who had already been removed from office in accordance with the Board's earher recommendations. ${ }^{260}$ Although Liu was found not to have been inotivated by malice or greed, said the Board, he nonetheless failed to supervise personally the initial investigation ${ }^{261}$ and therefore wrongly stated that the coroner's report was in order, extorted a confession from Hsiao-pai-ts'ai through excessive torture, permitted his underlings to badger Ch'ien T'an into making a false statement, and ignored various discrepancies. For these transgressions, Liu should be sentenced to permanent hard labor in the far northern region of Heilungchiang. Furthermore, because this case would not have been so vexing save for his errors, Liu should be made to suffer even more heavily by being denied the privilege, normally available both to officials and to men of his age, of being able to make monetary payments in lieu of actually undergoing punishment. ${ }^{262}$

258. IMPORTANT POLICIES, supra note 32, at 2:5a-8a.

259. Although amnesties apparently were declared more frequently in the period prior to the Yuian conquest (of 1279 A.D.), inany of the Ch'ing einperors issued amnesties when ascending the throne or in the early years of their reign. B. MCKNIGHT, THE QUALITY OF MERCY: AMNESTIES AND TRADITIONAL CHINESE Justice $95-98$ (1981).

260. TUNG-HUA RECORDS, supra note 32, at 366 . For a discussion of the penalty of removal from office, see T. METZGER, supra note 28, at 276-397.

261. The particular offense Liu was found to have committed was that of chien-yen shih-shang pu ishih [failing to carry out an accurate exammation of a corpse]. CH'ING CODE, supra note 76, at

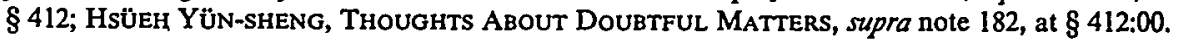
The summary of the case of Yang Nai-wu and Hsiao-pai-ts'ai is found in the part of $A \mathrm{New}$ Supplement to the Conspectus devoted to that offense. A NEw SUPPLEMENT to THE ConsPECTUS, supra note 32, at 15:1543. One major reason that the Ch'ing Code required magistrates, with only limited exceptions, personally to supervise the examination of corpses in murder cases arising within their districts was the fear that otherwise coroners inight deceive magistrates with false reports. CH'ING CODE, supra note 76, §412; see also supra note 143; infra note 431.

262. In being sentenced to "deportation" (fa-ch'ien) beyond the boundaries of the Middle Kingdoin, Magistrate Liu received the most severe penalty under $\mathrm{Ch}^{\prime}$ ing law short of 
The Board also recommended punishments for five nuembers of Magistrate Liu's staff. The coroner Shen Hsiang, declared the Board, went about his work sloppily and prepared a report that put the lives of two innocent people in jeopardy. ${ }^{263} \mathrm{He}$ should be sentenced to eighty blows of the heavy bamboo and two years in jail. The watchman Shen Ts'ai-ch'ulan helped cause the coroner's error by arguing with him during the autopsy, spread rumors about the case, and generally abused his master's authority. ${ }^{264}$ He should receive 100 blows of the heavy bainboo and be exiled 3,000 Chinese miles (li) from his home. For having badgered the late Ch'ien T'an into giving an inaccurate statement, the District Sub-Director of Studies Chang Chün should receive eighty blows and be removed from his position. ${ }^{265}$ And the yamen servants Chiang Wei-lung and Liu Tien-ch'en should each receive forty blows of the hight bamboo for having meddled in a situation that was none of their business. ${ }^{266}$

The Board also suggested sentences for a number of middle-level officials. The former Hangchow Prefect Ch'en Lu, said the Board, failed to scrutinize the judicial work of his subordinates with care, applied excessive torture to elicit a confession, refused to confront Yang with the druggist, and showed wanton disregard for human life. ${ }^{267}$ The Chekiang Judicial Commissioner K'uai Ho-sun did not carefully review the case but instead casually seconded the original verdict. ${ }^{268}$ The Ning-po Prefect Pien Pao-hsien, the Chia-hsing Magistrate Lo Tzu-sen, and the expectant magistrates $\mathrm{Ku}$ Te-heng and Kung Shih-t'ung, continued the Board, all ignored appreciable inconsistencies in the record while aiding $\mathrm{Hu}$ Jui-lan in his first review of the case. ${ }^{269}$ The expectant

death. Professors Metzger and Ch'u note that it was often possible for Ch'ing officials to redeem severe penalties, notwithstanding the efforts of the Yung-cheng Emperor and certain of his successors to narrow that privilege. CH'Ü T'UNG-TSU, LAW AND SocIETY, supra note 16, at 173-75; T. METZGER, supra note 28, at 303-07. Bodde and Morris indicate that under Ch'mg law, individuals over the age of 70 were entitled to redeem or reduce physical punishments, including banishment, through monetary payments. D. BODDE \& C. MORRIS, supra note 26, at 42; see also CH'ING CodE, supra note 76, at lxxiii; Bodde, Age, Youth and Infirmity in the Law of Ching China, in EsSAYS ON ChINA's Legal TRADITION, supra note 10, at 137, 147-50.

263. A NEW SUPPLEMENT to THE CONSPECTUS, supra note 32 , at 15:5143-44.

264. Id. at 15:5144. The offense of abusing a master's authority was a catch-all used to punish misconduct by yamen staff members. HsüEh YüN-SHENG, ThOUGHTS ABOUT UNCERTAIN MATTERS, supra note 182, at 365:03.

265. A New Supplement to THE Conspectus, supra note 32, at 15:5145.

266. Id. Chiang and Liu's specific offense appears to have consisted of providing Mrs. Shen, before her trip to Peking, with letters seeking financial help for her from their former inaster, Wen Ch'ao, who was now employed at the Board of Punishments. IMPORTANt Policies, supra note 32, at 2:6b-7a. Typically, in the late Ch'ing, the state did not provide adequate living expenses for witnesses.

267. A New Supplement to the Conspectus, supra note 32, at 15:5144.

268. Id.

269. TUNG-HUA ReCORDS, supra note 32, at 366. 
magistrate Cheng Hsi-kao failed to carry out a thorough secret investigation when assigned to do so by Governor Yang Ch'ang-chün. All of these officials, with the exception of K'uai Ho-sun, who passed away in late $1875,{ }^{270}$ should therefore be punished by being removed from the offices that they now hold. ${ }^{271}$ On the other hand, continued the Board, the Hu-chou Prefect Hsi Kuang and those who worked with him did not reach any conclusions when they investigated the case and therefore reported no misinformation. No recommendation of punishnient ought to be made for thein. ${ }^{272}$

As for higher officials, the Board noted that Chekiang Governor Yang Ch'ang-chün not only proved incapable of ferretimg out the mjustices perpetrated by officials under him when hc initially exammed the case, but also failed to ascertain the truth when later asked by the Throne to review the case following Yang Nai-wu's ching-k'ung petition. ${ }^{273}$ Moreover, Governor Yang subsequently protested against the decision to retry the case in Peking. The Board also criticized Hu Juilan for disregarding the significant factual discrepancies he uncovered and for accepting without reservation Magistrate Liu's origimal report. ${ }^{274}$ Through his indifference to the truth and his mability to reach the bottoin of the inatter, stated the Board, Hu demonstrated that he lacked the reliability and skill that are to be expected of officials of his rank. Botlı men, concluded the Board, should be renroved froin office. $^{275}$

Turning to the original instigator of the case and to those who aided lier, the Board noted first that while it was evident that Mrs. Shen had been upset by the strange death of her son, that fact should not wholly excuse lier froin punishment for having altered her statement and knowingly inade a false accusation of inurder agaimst Yang Naiwu and Hsiao-pai-ts'ai. ${ }^{276}$ The Board, however, taking account of the circumstances, urged that she be sentenced to a puinshment one degree lower than that normally accorded individuals making false accusations of inurder that do not result in the accused's execution. It recominended that she be given 100 blows of the heavy bamboo and be

270. A New SUPPLEMENT TO THE CONSPECtus, supra note 32, at 15:5144.

271. Id. at 15:5144-46.

272. Id. at 15:5144. The Board of Punishments' treatment of Hsi Kuang and the members of his commission suggests that inaction may have been the key to survival in the bureaucracy, despite many laws imposing affirmative obligations upon officials. Exanples of such laws are discussed in T. METZGER, supra note 28, at 391-96.

273. A New Supplement to the Conspectus, supra note 32, at 15:5144.

274. TUNG-HUA RECORDS, supra note 32, at 366.

275. Id. at 366 .

276. A New Supplement to the Conspectus, supra note 32, at 15:5144-46. Inperial Chinese law dealt with false accusations severely. CH'ING CODE, supra note $76, \S 336$. 
sentenced to four years in jail. ${ }^{277} \mathrm{Her}$ husband Shen T'i-jen, his relative Wang Hsin-p'ei, and the neighborhood official Wang Lin, continued the Board, all offered testimony at the district yamen in support of her imitial petition. However, as none of these people were involved in her subsequent falsehoods, they ought all to be spared punishment. ${ }^{278}$ On the other hand, were he still alive, the licentiate Ch'en Chu-shan ought to be punished for the way in which he helped bring about the druggist Ch'ien Tan's erroneous statements about Yang Nai-wu. ${ }^{279}$

Finally, the Board noved to Hsiao-pai-ts'ai and Yang Nai-wu. ${ }^{280}$ Although Hsiao-pai-ts'ai was innocent of the major charges of committing adultery with Yang Nai-wu and murdering her husband, declared the Board, she ought to receive eighty blows of the heavy bamboo for two lesser transgressions. ${ }^{281}$ The first was that of laying false accusations and fabricating evidence under extreine duress produced by torture. The second, which derived frow her eating and joking with Yang, was that of acting in a manner inappropriate for a narried woinan. Yang Nai-wu was similarly innocent of the major charges of adultery and murder. ${ }^{282}$ However, in eatimg and joking with Hsiao-pai-ts'ai and reading the Classics to her, he did not act as a holder of the chï-jen degree ought to have acted. ${ }^{283}$ Additionally, although Yang was not inotivated by inalice but was merely trying to secure his owu freedo1n when he accused Ho Ch'un-fang and others of having cavorted with Hsiao-pai-ts'ai, the fact remained that he did commit the offense of being a convict who knowingly accuses an innocent person of a crime. Therefore, it recommended that Yang receive 100 blows of the heavy bamboo and that he not be allowed to recover his chü-jen degree.

On March 30,1877, the Throne finally brought this case to its conclusion by ordering that all sentences recommended by the Board of Purishments be implemented at once. ${ }^{284}$

To the extent records are available, it is evident that the sentences

277. A New Supplement to the Conspectus, supra note 32 , at 15:5145.

278. Id.

279. Id.

280. Id. at 15:5145-46.

281. Id. In rendering its final judgment, the Board of Punishments does not appear to have addressed the possibility that Hsiao-pai-ts'ai committed adultery with anyone other than Yang Nai-wu. This raises some question as to the accuracy of various nasty rumors that circulated about her. See supra text accompanying notes 104, 188.

282. A NEW SUPPLEMENT TO THE CONSPECTUS, supra note 32, at 15:5144-46.

283. In the Board's estimation, by eating and joking together, Yang Nai-wu and Hsiao-paits'ai had violated the section of the Ch'ing Code which prohibited that which "ought not to be done." Ch'ING CODE, supra note 76, § 386; D. BODDE \& C. MORRIS, supra note 26, at 178; HsüEH YÜN-SHENG, Thoughts ABOUT UNCERTAIN MATTERs, supra note 182, at 386:00; see also supra text accompanying note 87.

284. A New Supplement to the Conspectus, supra note 32, at 15:5143; TUNG-HUA RECORDS, supra note 32, at 365-66. 
recommended were implemented, at least initially. Of the three officials most directly implicated in the case's errors, two-Liu Hsi-t'ung and $\mathrm{Hu}$ Jui-lan-never recovered sufficient stature to be reappoimted to official positions. ${ }^{285}$ The third, Yang Ch'ang-chun, spent almost two years without a government position before using his own influence and that of his major benefactor, Tso Tsung-t'ang, to secure an appointment as an aide to Tso, who was then leadimg the imperial government's fight against the Moslem rebels of the Northwest. ${ }^{286}$ As a reward for his efforts at suppressing the Moslems, Yang Ch'ang-chun was later appointed Governor of Kansu. ${ }^{287}$ Of the three censors who wrote memorials criticizing the manner in which the case was conducted, only Pien Pao-ch'üan is mentioned in any of the thirty-three standard sources of Ch'ing biograplyy. ${ }^{288}$ The memorial which Pien submitted on November 15, 1875 proved to be the cornerstone of his reputation as a pillar of imtegrity. Pien subsequently had a distinguished official career which included service as Governor-General of the provinces of Chekiang and Fukien. ${ }^{289}$ None of the three leaders of the group of eighteen Chekiang officials who memorialized for a retrial is treated in any of the standard biographies. After the completion of the case, Hsiao-pai-ts'ai entered a Buddhist nunnery where she remained for the rest of her life. Yang Nai-wu reportedly returned to Yü-hang briefly and then moved to Shanghai, where he eventually became an editor of the Shen Pao-the newspaper that had publicized his case. ${ }^{290}$

\section{III \\ The Nature of the formal Criminal Justice Process IN LATE IMPERIAL CHINA}

\section{A. The Process as It Was Meant to Work}

The case of Yang Nai-wu and Hsiao-pai-ts'ai inerits our attention because it provides a comprehensive understanding of the manner $\mathrm{m}$

285. Chamber ReCollections, supra note 100 , at 388-89.

286. For biographical information on Tso Tsung-t'ang, see W. Bales, Tso Tsung-T'ANo (1937);.G. Chen, Tso Tsung-T'ANo (1938); EMINent Chinese, supra note 195, at 762-67.

287. Fang I, Chinese Biographical Dictionary, supra note 179, at 1266; H. Giles, BioGRAPHICAL DICTIONARY, supra note 179, at 894. The Governorship of Kansu in China's northwest was far less desirable a post than the Chekiang Governorship that Yang Ch'ang-chun had earlier held.

288. The names of all individuals treated in the 33 major Chinese language collections of Ch'ing biographies are indexed in SAN-SHIH-SAN-CHUNo Ch'ING-TAI CHUAN-CHI TsUNG-HO Yin-te [IndeX to Thirty-Three Standard Collections of Ch'ino Biographies] (Fang Chao-ying \& Tu Lien-che comps. 1932).

289. For biographical information on Pien, see Fang I, Chinese Blographical DictionARY, supra note 179 , at 1760 .

290. Chao K'e-chun, Injustice, supra note 33, at 31 . 
which the imperial criminal justice process was intended to work and did, in fact, work. Four inajor types of formal checks upon the district nagistrate's discharge of his legal responsibilities are apparent in the case. $^{291}$ Although these checks clearly did not always work as intended, it is useful initially to review how they were ineant to operate.

The first check consisted of elaborate sets of rules designed to regulate virtually every aspect of the inagistrate's official duties. Penal and administrative laws and regulations establisled compreliensive standards regarding matters mcluding the appreliension, interrogation, trying, and sentencing of felons. ${ }^{292}$ For example, these rules prescribed that all persons accused of committing a single crime be confronted with one another. They also specified in detail the type and degree of torture that could be applied in order to extract needed confessions. ${ }^{293}$ Violations of these rules by magistrates carried a variety of punisl1ments, ranging froin nominal demerits to removal froin office, after which the former official could be tried as a common criminal. ${ }^{294}$

The second check built into the formal criminal justice process was the so-called "obligatory review system." Magistrates could impose and carry out sentences only in cases involving penalties no inore severe than beatmg witl a lieavy bamboo, ${ }^{295}$ a relatively minor sanction. In cases involving more serious punishments, magistrates were limited to passing provisional sentences (ni) that liad to be reviewed as a natter of course by higher level officials. The lieavier the sentence given, the more levels of official review it had to pass before it could be carried out. Prior scrutiny by the Einperor himself was inandated in virtually all deatli penalty cases. ${ }^{296}$

291. There were also imformal, nongovernmental checks upon the judicial behavior of magistrates, including the influence of local gentry. See 1 CHANG WejEN, LeGaL SyStem, supra note 30, at 155; Ch'Ü T'UNG-TSU, Local Government, supra note 16, at 168-92; HsiaO KungChUAN, RuRal ChINA, supra note 59, passim; J. WATT, supra note 29, passim.

292. These laws and regulations are described generally in CH'Ü T'UNG-TSU, Local GovERNMENT, supra note 16, at 116-29; T. METZGER, supra note 28, passim; Shiga, Criminal Procedure (II), supra note 30, passim. They are contained, for example, in CH'ING CODE, supra note 76; Ch'IN-TING Ch'UNG-HSIU CH'U-FEN TSE-LI [The IMPERIALLY ENDORSEd AND REvised Regulations on Administrative Punishments] (1887); TA-ch'ing Hui-tien [The Collected StatuTES OF THE GREAT Ch'ING DYNASTY] (Taipei reprimt 1963); and TA-Ch'ING HuI-TIEN ShIH-LI [Precedents and Regulations Supplementing the Collected Statutes of the Great Ch'ing Dynasty] (Taipei reprint 1963).

293. See, e.g., Ch'ing CODE, supra note 76, § 404.

294. CH'U T'UNG-TSU, LOCAL GovernMENT, supra note 16, at 128-29.

295. D. BODDE \& C. MORRIS, supra note 26, at 116.

296. Shiga, Criminal Proeedure (I), supra note 30, at 16-19. There were two situations in which officials were not required to seek imperial approval before carrying out death sentences, although in each case they were required to file detailed reports immediately afterward. The first exception permitted the execution of rebels on the spot (chiu-ti cheng-fa ch'ang-cheng). D. BODDE \& C. MorRIS, supra note 26, at 142-43. Although the largest rebellions in Chinese history were quelled during this period, we know too little to determine how widespread summary executions 
An appellate procedure known as the shang-k'ung, ${ }^{297}$ through which an individual could protest a decision to higher authorities, served as a third check. As soon as one's district level trial was coinplete, one could directly petition either those officials of the provincial government responsible for that district magistrate or specified entities in Peking. ${ }^{298}$ At the time that the case of Yang Nai-wu arose, Ch'ing law ${ }^{299}$ provided that officials in Peking receiving appellate petitions could either refer the case at issue to the Emperor or send it back to the governor of the province in which it had originated for further consideration..$^{300}$ The Einperor could affirm or reverse the origmal verdict, dispatch a special commission to investigate the matter, order the Board of Punishments to reexamine the case itself, or refer the case to the appropriate provincial governor. ${ }^{301}$

The fourth inajor formal check lay in the supervisory authority that the magistrate's direct provincial superiors, circuit (tao) intendants, and censors were required by law to exercise. This authority took three distinct forms. First, those officials directly above the magistrate in the line of official authority-prefects, judicial commissioners, and governors-not only heard cases arising through both the obligatory review and appellate systeins but also had an affirmative legal obhigation to uncover and report all wrongdoing committed by officials beneath them. ${ }^{302}$ Second, circuit intendants were empowered to conduct annual reviews of all cases heard at the district level. ${ }^{303}$ And third, innerial censors who, at least nominally, enjoyed a high degree of independence, were responsible for ferreting out abuses committed by officials and for reinonstrating with the Einperor. ${ }^{304}$ To foster their independence, imperial censors were not supervised by the Board of Punish-

were in the late Ch'ing. The second exception concerned persons found to have committed a small number of particularly hemous offenses (such as killing one's parents). This was viewed as carrying out the Emperor's will by proxy (kung-ch'ing wang-ming). Shiga, Criminal Procedure (I), supra note 30 , at 21 .

297. See supra note 184.

298. Censorate Regulations, supra note 184, at 14:9b; see also supra notes 184-86 and accompanying text.

299. Shiga, Criminal Procedure (1), supra note 30, at 33.

300. Prior to 1799, officials in Peking were also free to issue final rejections of ching-k'ung petitions. See infra note 316.

301. Shiga, Criminal Procedure (I), supra note 30, at 33-34. Bodde and Morris question the degree to which Emperors took seriously their task of reviewing all death sentences. D. BODDE \& C. MORRIS, supra note 26, at 140-42. The diligence with which the K'ang-hsi Emperor (who reigned from 1662-1722) approaehed this task suggests that at least some Emperors took this responsibility to heart. J. SPENCE, EMPEROR OF ChINA: SELF-PORTRAIT OF K'ANG-HSI 32-34 (1974).

302. T. METZGER, supra note 28, at 294-97, 390-96 \& passim.

303. Shiga, Criminal Procedure (I), supra note 30, at 37-38.

304. See generally C. HuCker, The Censorial System of Mino China (1966); T. MetzGER, supra note 28 , at 269-71. See also infra notes $362-68$ and accompanying text. 
ments, but were allowed to communicate directly with high-level authorities, including the Emperor. ${ }^{305}$

\section{B. The Process as It Actually Worked}

As the case of Yang Nai-wu and Hsiao-pai-ts'ai illustrates, in practice the four inajor formal checks upon a magistrate's exercise of authority did not always operate as intended..$^{306}$ Compliance with the elaborate rules governing a magistrate's judicial behavior, including those provisions designed to limit the degree of torture that could be applied to elicit an acknowledgeinent of guilt, ultimately depended heavily upon the individual magistrate and his staff. ${ }^{307}$ If he chose to transgress these bounds, as Magistrate Liu Hsi-t'ung did when applying torture to Hsiao-pai-ts'ai, or if his staff erred, ${ }^{308}$ as Magistrate Liu's did

305. I. Hsü, supra note 5 , at 53 .

306. For examples of the way in which a range of persons in the late Ch'ing viewed difficuIties of the type found in the case of Yang Nai-wu and Hsiao-pai-ts'ai as afflicting the operation of the formal criminal justice process in general, see CENSORATE Regulations, supra note 184, at 14:49b-50a (edict of the Kuang-hsu Emperor) \& passim; the inemorial of the censor Ch'en I found in the Peking Gazette of July 20,1875; the memorial of the censor Teng Ch'ing-lin found in the Peking Gazette of Aug. 18, 1875; supra text accompanyimg notes 215, 256-57; infra text accompanying notes 315-31, 370-77. See also Chao K'e-chun, Injustice, supra note 33, at 15 . To say that the problems encountered in this case were viewed by many observers at the time as being wide spread is not, of course, to suggest that all cases of this era were beset with such troubles. For a more extended discussion of factors that we must consider before forming definitive judgments about the operation of the imperial criminal justice process, see infra text accompanying notes $399-432$.

307. Ch'Ü T'Ung-TSU, Local Government, supra note 16, passim; Hsiao Kung-ChUAN, supra note 59 , passin, J. WATT, supra note 29 , passim. This is not to suggest that the ch'u-fen tse-li and relatcd laws and regulations specifying how officials were to carry out their duties were meaningless. Administrative sanctions could be imposed upon officials violatimg these rules. These sanctions included dismissal from office, after which an official could receive severe criminal punishments-as did former Magistrate Liu Hsi-t'ung. See supra text accompanying notes 260-62. Nonetheless, judging from the memorials of the censors Wang Shu-jui, Pien Pao-ch'ulan and Wang Hsin in this case, one might conclude that at least in the late Ch'ing, enforcement nay have been less than ideal. See supra text accompanying notes 213-15, 254-57. Kao I-han suggests that in the late Ch'ing, the principal responsibility for enforcement was entrusted to line officials (i.e., to the violating official's superiors in the normal hierarchy). KAO I-HAN, CHUNG-KUO YÜ-SHIH Chih-TU TE Yeh-Ko [The Evolution of the Chinese Censorial System] 77-89 (1926) [hereinafter cited as KAO I-HAN, EvOLUTION]. If so, this practice may partially explain the enforceınent problems. For just as superior line officials handling automatic reviews or shang-k'ung petitions were often loath to review the actions of subordinatcs rigorously, so too, they may have hesitated to enforce the ch'u-fen tse-li and related laws strictly. They might have been motivated by lassitude, friendship with subordmates, or a fear that too many violations might lead their superiors to assume that they were doing a poor job of supervising their subordinates. Professor Metzger acknowledges that admimistrative discipline was not as well enforced during the late $\mathrm{Ch}$ 'ing as in earlier times, but attributes this decline to the corruption engendered by the Empress Dowager Tz'u-hsi. T. METZGER, supra note 28, at 398.

308. As a number of the scholars cited supra in notes $14,16-18$ and 29-30 have shown, the potential of district inagistrates and their staffs for administering the law imcorrectly ought not to be ininimized. Magistrates rarely received formal training in law. As a consequence, they appear to have been hcavily rehant for legal guidance upon so-called "private secretaries" specializing in 
both in examining Ko P'in-hen's corpse and in interrogating Ch'ien T'an, there was nothing that those suffering at his hands could do by way of redress until the damage had been imflicted. And even then, the possibility that such individuals could vindicate themselves through either the obligatory review system or the shang-k'ung was limited in at least four key respects.

The first problem in the obligatory review system and shang-k'ung appellate procedure lay in the willingness of higher level officials to

legal matters. Among the magistrate's most important aides, the legal secretary typically had acquired his legal expertise either through informal study or through experience with other legal secretaries or magistrates. His tasks included drafting mitial orders, determining hearing dates, counseling the magistrate before and after trial (typically he was not permittcd to attend trial, but had to rely upon written statements supplemented verbally by the magistrate), drafting reports of cases going to higher levels, aud preparing preliminary responses to questions raised at those higher levels. CH'Ü T'UNG-TSU, LOCAL GovERNMENT, supra note 16, at 93-107. Not surprisingly, good legal secretaries were hard to come by, as evidenced by efforts-often involving considerable artifice - to evade a law limiting their term in any one district to five years. 1 CHANG WeJEN, LEGAL SYSTEM, supra note 30, at 162-63.

The complexity of the law also compounded the possibility that magistrates and their legal secretaries would make mistakes. The laws were many and intricate. In the late Ch'mg the imperial code, which itself ran to some 436 articles $(i a)$, was supplemented by over 1000 sub-statutes (ii). Many provisions were highly specific and yet "[i]n determining a sentence, a nagistrate could refer to only [the] one particular law or statute [most] applicable to that case." CH'Ú T"UNG-TSU, LOCAL GOVERNMENT, supra note 16, at 126. Conversely, other provisions, like the one allowing the execution of rebels without imperial permission, were quite vague. See supra note 296.

To make matters worse, the law imposed upou magistrates deadlines for apprehending criminals and resolving related legal matters that were strict and that may, at times, have been unrealistic. These deadlines, enforced by substantial penalties, created pressure upon the inagistrates to resolve matters rapidly. Moreover, there were no systematic case reports and only limited official glosses, although private commentaries were of considerable significance to $\mathrm{Ch}^{\prime}$ ing dynasty magistrates and legal secretaries (even if few were wdling to cite them in their case reports). Chen, Shen Chih-chit, supra note 29, at 170, 203-04.

Another probable source of error was the size of the magistrate's staff, which inight number many hundred in a typical district and more than a thousand in a larger district. So-called "runners," who might be coroners, jailers, policemen, guards, grooms, messengers, watchmen, or others, were the magistrate's most direct link with the people. As the case of Yang Nai-wu shows, they were not always the most skilled or careful of employees. See, e.g., supra text accoinpanying notes 147-50. To make matters worse, runners and even higher level members of the magisterial staffs, including legal secretaries, were expected to earn most of their upkeep by collecting fees from the people and so had an imcentive to prey upon the populace and to accept bribes. 1 Chang Wejen, Legal System, supra note 30, at 234 n.166.

Finally, the nature of the legal profession in imperial China may have contributed to errors at the magisterial level. At least in the late Cl'ing, there inay have been more and better educated individuals providing legal advice to the populace than the stereotype of the litigation trickster suggests. Yang Nai-wu was one. Nonetheless, because there were no minimum standards for such advisors and because criminal defendants were not free to bring legal advisors with them into the magistrate's yamen, there were clear limits to the ability of such speciahists to aid persons not versed im legal matters. Presumably such counselors were not nccessary in the yamen because the magistrate was not viewed as an advocate for either side, but iustead was obligated by law and morality to find the truth. Nonetheless, it is plausible that access to a legal advisor like Yang Naiwu would have appreciably assisted a typical peasant appearing before a highly educated district magistrate who could consult his legal secretary. 
accept without serious reexamination the findings of subordinates, ${ }^{309}$ notwithstanding laws requiring prefects, judicial commissioners, provincial governors, and capital officials thoroughly to reinvestigate and retry cases coming to them from lower level courts, particularly when those cases included repudiated confessions. Although such officials were subject to admimistrative punishments if they affirmed judicial errors, ${ }^{310}$ the behavior of Prefect Ch'en Lu, Judicial Commissioner K'uai Ho-sun, and Governor Yang Ch'ang-chün suggests that at least some late Ch'ing officials acted as if the possibility of being sanctioned were an empty threat. ${ }^{311}$ Another factor reinforcing this attitude may have been the Ch'ing practice of punishing not only magistrates, but their superiors as well, for errors made at the magisterial level. ${ }^{312}$ Reversal of a conviction in a murder case by a magistrate's superiors would leave that magistrate and his superiors with an unresolved murder, ${ }^{313}$ which could be a serious impediment to bureaucratic advancement. If, as the case suggests, this tendency of higher officials to accept the findings of their subordmates more readily than complamts of the convicted was widespread, ${ }^{314}$ it would have significantly undermined the effectiveness of the obligatory review systein and the shang-k'ung.

A second and related flaw lay in the mamier in which high-level provincial officials reviewed major appeals directed to thein from Peking. The case of Yang Nai-wu was but one of many appeals that the Throne came to believe had not been reviewed in a serious and fair fashion. ${ }^{315}$ Whether attributable to the unrelenting increase in appeals during the nineteenth century, ${ }^{316}$ to the tendency of officials in Peking

309. See, e.g., supra notes 179-83, 200-01 and accompanying text.

310. CH'Ü T'UNG-TSU, LOCAL Government, supra note 16 , at 128.

311. Shiga Shuzo states that "[a] governor in all probability, seldoin rejected [a] provisional sentence approved by the judicial commissioner." Shiga, Criminal Procedure (I), supra note 30, at 24. Bodde and Morris state that "the . . . prefecture . . . in legal matters seems often to have functioned inerely as an agent for transmitting cases to a higher level." D. BODDE \& C. MORRIS, supra note 26, at 115 . Bodde and Morris' notion, which has since been shown by both Shiga Shuzo and Chang Wejen to be erroneous, may have arisen from the apparent tendency of prefects and provimcial authorities to approve provisional sentences reached by magistrates. See 1 CHANG WeJEN, LeGAL SYSTEM, supra note 30, at 169-70.

312. Ch'Ü T'UNG-TSU, LoCAL Government, supra note 16, at 121-22, 128.

313. Even if a conviction were overturned within the specified time period, there would be a significant risk that a renewed investigation long after the fact would not turn up a new perpetrator.

314. See supra text accompanying notes 187-91, 256-57, 306.

315. Censorate Regulations, supra note 184 , at $14: 49 \mathrm{~b}-50$ a.

316. By the late $\mathrm{Ch}^{\prime}$ ing, inore than 100 ching-k'ung appeals were being inade annually from each inajor province. TUNG-HUA RECORDS, supra note 32, at 1414. The Throne attributed this, at least in part, to the incorrect interpretation by timid capital officials of instructions given by the Chia-ch'ing Emperor (who reigned from 1796 to 1820 ) to entertain all ching-k'ung petitions. The Chia-ch'ing Emperor's real intention, said the Throne in 1882, was that capital officials receive all najor cases (in part because such cases provided him a picture of bie in the provinces not otherwise available), but dispense rapidly with those that were minor. See generally CENSORATE REG- 
to send appeals back to officials who had previously heard them, ${ }^{317}$ to the aftermath of the mid-century rebellions, ${ }^{318}$ or to other factors, this problem seems to have been on the rise during the T'ung-chih and early Kuang-hsü reigns. To be sure, special miperial commissions of the type seen in this case were meant to be a device for alleviating these particular difficulties. ${ }^{319}$ By the late nineteenth century, however, such commissions were appointed only in extraordinary situations, such as that created by Yang Nai-wu's second and more sharply worded appeal. ${ }^{320}$ Moreover, they were handicapped by their relative unfamiliarity with the regions to which they were sent and their concomitant need to rely on the very local officials whose work they would be scrutinizing. ${ }^{321}$

The publicity generated by the case of Yang Nai-wu and Hsiaopai-ts'ai helped spur efforts to reform the ching-k'ung procedure. In a May 1875 memorial, the censor Wang Hsm urged the Throne not to view the troubles that had arisen in the official disposition of the case of Yang Nai-wu as explicable solely by the inadequacies of the particular individuals involved..$^{322}$ These troubles ought also, urged Wang, to be seen as outgrowths of the practice of remanding appeals back to officials who had previously been involved in the case that was the subject of the appeal..$^{323}$

While the Throne did not act upon Wang's memorial, the general points he made appear not to have gone unheeded in official circles. Others holding the opmion that the ching-k'ung was no longer operating as intended took it upon themselves to express their views to the

ULATions, supra note 184. I am indebted to Mr. Chen Mingmian of the Law Department of Zhongshan University for helping me to understand this point.

317. Shiga, Criminal Procedure (I), supra note 30, at 24-25, 33-34. The rationale for returning a case to officials who had previously heard it appears to have been that such officials would be more familiar with it than someone not previously involved.

318. See infra notes 351-55 and accoinpanying text.

319. Shiga, Criminal Procedure (I), supra note 30, at 33-34.

320. Censorate Regulations, supra note 184, at 14:34b. Scholars have yet to undertake comprehensive empirical studies of the background of persons utibzing the ching $-k^{\prime} u n g$ procedure. It would be interesting to know more about both the extent to which persons initiating such appeals were inembers of imperial China's social, financial, or cducational elite and the degrce to which legal counselors were involved in shaping such petitions, especially outside of the imperial capital. Obviously, being both a chï-jen and a person skilled at preparing lcgal papers, Yang Naiwu was unusually well suited to utilize this procedure. It would also be worthwhile to try to determine the accuracy of statements by the Throne in 1882 to the effect that at lcast some persons making such appeals were knowingly doing so improperly in order to imtimidate local officials and other persons. Id. at $14: 49 \mathrm{~b}-50 \mathrm{a}$.

321. The small size of special commission staffs was a particular problem, given the range of dialects and local customs found throughout China.

322. T'UNG-HUA RECORDS, supra note 32, at 345-47.

323. Id. 
Throne. ${ }^{324}$ One such official was Hunan Governor Pien Pao-ti, who in an 1882 memorial argued that the ineffectuality, injustice, and delay that increasingly marked the handling of ching-k'ung appeals could not be cured without substantially reducing the number of cases that highlevel provincial and capital officials were responsible for reviewing. ${ }^{325}$ Only if such officials were spared the need to focus upon cases involving relatively minor matters could they approach inore serious ones with appropriate care and concern for justice. ${ }^{326}$

The Throne was receptive to Pien's analysis of the problems with the ching-k'ung procedure. ${ }^{327}$ In September of 1882, it ordered the Cominandant of Gendamerie and others in the capital charged with receiving ching-k'ung petitions to clear away relatively minor appeals in order that appropriate attention could be concentrated upon major cases. ${ }^{328}$ Henceforth, capital officials should direct cases that they beheved to be minor to independent supervisory personnel at the locality froin which the case had arisen, provided that the remanding authorities were certain that the case would be reviewed fairly. ${ }^{329}$ Major cases were to be treated with far greater care. They were not to be sent to such low-level officials but rather were to be directed to either provincial governors or their judicial commissioners. ${ }^{330}$ Moreover, to guard against any unfairness on the part of such officials, the Throne ordered that henceforth in each sucl case provincial officials both be charged with special imperial instructions to review the matter as scrupulously as possible and be required to explam in detailed periodic written reports why they reached the decision they did, rather than merely to state their conclusions. ${ }^{331}$

Although the changes ordered by the Throne in 1882 were designed to alleviate problems im the ching-k'ung of the type manifested by the case of Yang Nai-wu and Hsiao-pai-ts'ai, the extent to which they attaimed that end is unclear. ${ }^{332}$ But however much they may have improved the ching-k'ung procedure, they did little to remedy two further problems with the formal criminal justice process evidenced by this case. The first was that of undue political influence ${ }^{333}$ arising from

324. See, e.g., the memorial of the censor Teng Ch'ing-lin. Peking Gazette, Aug. 18, 1875.

325. T'UNG-HUA RECORDS, supra note 32, at 1414-16.

326. Id. at 1415-16. Pien also urged that steps be taken to deal harshly with those abusing the ching-k'ung procedure.

327. Id. at 1414-16.

328. Id.

329. Id. at 1415.

330. Id. at 1416 .

331. Id.

332. The degree to which these changes transformed the manner in which high-level provincial officials actually reviewed appeals remains to be exanined.

333. Although less felicitous, the phrase "undue political influence" has been used instead of 
regional or ideological loyalties, shared preparation for the imperial examinations (t'ung-hsüeh), and friendship. The second was tension between the provincial and central governments.

A recurrent phenomenon throughout Chinese history, especially when the imperial figure and central government were weak, the problein of undue pohtical influence was particularly acute during the decade of the 1870 's. In this period imperial authority was eroded by the aftereffects of the mid-century rebellions, the incursions of the Western powers, and the atteinpts of the Empress Dowager Tz'u-hsi to ensure her power by breaking the rules of succession and mstalling a threeyear-old child as Emperor. ${ }^{334}$

The problem of undue political influence had a deleterious effect upon the forinal criminal justice process. It often led to the appointment of relatively unqualified individuals to official positions, as is demonstrated by the examples of Liu Hsi-t'ung and Yang Ch'angchün. ${ }^{335}$ Liu Hsi-t'ung may have been appointed to three separate terins as inagistrate of Yü-hang because he had been a classmate and friend of the powerful Grand Secretary Pao-yün. ${ }^{336}$ There is nothing in the records to suggest that lie was a man of such unusual abilities or accoinplishinents as to warrant three distmct appointınents. ${ }^{337}$ To the contrary, the Yü-hang gentry seem to have held Magistrate Liu in low esteen, and there is even a suggestion that he may have been corrupt. ${ }^{338}$ The appointment of Yang Cli'ang-clün as Governor of Chekiang shows that the problem of political connections was not limited to the district level. Although he liad neither a chin-shih degree nor experience in civil administration, Yang was nained Governor of that

the term "factionalism" because of the particular connotations of the latter term in Chinese history. See, e.g., Cambridge EnCyclopedia of China, supra note 6, at 212.

334. For a discussion of these three factors in the context of China's struggle to modernize in the late 19th century, see R. SMITH, supra note 17, at 242-53.

335. Governor Yang's background is discussed supra in note 179. Professor Liu observes in his insightful essay for The Cambridge History that "[t]he quahity of most office-holders seems . . . to have deteriorated in the meantime [1850-1870]." Liu Kwang-ching, The Ch'ing Restoration [hereinafter cited as Liu Kwang-ching, Restoration], in 10 THE CAMBRIDGE History of CHINA, LATE CH'ING, 1800-1911, PART I, at 478 (J. Fairbank \& D. Twitchett eds. 1978) [hereinafter cited as The CAmbridge History of ChINA]; see also id. at 478-81. Notwithstanding this decline, Professor Liu is of the view that later, in the 1870's, the imperial governinent was able to reassert some ineasure of control over official appointınents. Id. at 481-90.

336. By the mid-1870's, the Manchu Pao-yun, who had earued his chin-shih in 1838 along with Liu Hsi-t'ung, was a Grand Secretary, Grand Councillor, Chancellor of the Hanlin Academy, and leading official at the Tsungli Yamen. H. Giles, Biographical Dictionary, supra note 179, at 620; M. Wright, The Last Stand of Chinese Conservatism 82, 228-29, 248 (1966).

337. CASE History, supra note 100 , at 358 . The tenure for district magistrates actually grew shorter during the period of the T'ung-chih Restoration (1862-1874). Liu Kwang-ching, Restoration, supra note 335 , at 479.

338. See supra text accompanying notes 231-33. 
important province at a relatively young age on the strength of his military successes and the political alliances he had forged in the effort to suppress the great imd-century T'ai-p'ing uprising. ${ }^{339}$

The problem of undue political influence further hindered the formal legal process by minimizing the possibility that well-connected officials would receive punishınents, thus reducing their incentive to follow closely the many rules designed to govern their behavior. The hesitancy of the Board of Punishınents to apply clearly appropriate sanctions to politically well-aligned officials is illustrated by the Board's deliberations regarding Liu Hsi-t'ung, Hu Jui-lan, and Yang Ch'ang-chün. After the Board had retried the case in Peking and Liu had confessed his errors, Board President Tsao-pao and others were still reluctant to recommend punishment for Liu, in spite of his being a mere magistrate, apparently because he was linked to a major official in the capital. ${ }^{340}$ The Board's unwillingness to enforce the law against officials with powerful friends is inore evident in the cases of Hu Juilan and Yang Ch'ang-chun. Even after the Board had determined that Liu's original report had been laccd with errors, in deliberations held immediately after the retrial in Peking the Board chose not to consider whether any of Liu's superiors had committed the offense of ratifying the conviction of an innocent individual. This was primarily because the Board's presiding officers were well aware that Yang Ch'ang-chün and $\mathrm{Hu}$ Jui-lan were fellow provincials and friends of the powerful General Tso Tsung-t'ang, who had played a inajor role in suppressing anti-imperial rebels. ${ }^{341}$ And even at the end of the case, when the Board did recommend punishments for them, it did so hesitantly.

Moreover, undue political influence frequently prevented the correction of judicial errors. In Yang Nai-wu's case, this was most evident in the willingness of the Special Imperial Commissioner Hu Jui-lan to affirm the convictions of Yang Nai-wu and Hsiao-pai-ts'ai, notwithstanding the many discrepancies his Commission had uncovered. While available materials do not reveal whether Governor Yang may have influenced the selection of $\mathrm{Hu}$ Jui-lan as Special Commissioner, they indicate that these two Hunanese, who had earlier jointly memorialized the Throne regarding other political matters, were indeed quite friendly ${ }^{342}$ Political connections may also have been at work in the refusal of the Throne to follow Pien Pao-ch'üan's memorial accusing $\mathrm{Hu}$ and Yang of collusion and asking that the case be brought to Pe-

339. Fang I, Chinese Biographical Dictionary, supra note 179, at 1266; H. Giles, BioGRAPHICAL DICTIONARY, supra note 179 , at 894.

340. LI TZ'U-MING, DIARY, supra note 32, at 4941-42.

341. Id.

342. Peking Gazette, Jan. 10, 1876; id., Mar. 9, 1876. 
king for retrial, although the relative paucity of material about the imner workings of the imperial court at this poimt makes this suggestion difficult to prove. ${ }^{343}$

Interference in the criminal justice process by gentry, despite statutory restrictions upon their imvolvement in judicial matters to which they were not party, may have constituted yet another form of undue political influence. Although the involvement of officials froin Chekiang in Yang Nai-wu's case ultimately proved to be salutary, the possibility exists that tensions between Magistrate Liu Hsi-t'ung and meinbers of the Yü-hang gentry may have had as much to do with their involvement as any sympathy for the defendants or even any generalized concern with seeing justice done. One important source suggests that Magistrate Liu was at odds with the local gentry, ${ }^{344}$ and the local gazetteer indicates that Liu was abruptly removed from office during his terin. ${ }^{345}$ The eighteen officials from Chekiang who asked the Throne to bring the case to Peking may have been motivated in part by a sense that Magistrate Liu Hsi-t'ung was now vulnerable and perhaps could be dislodged from Yü-hang. Confirunation for this view can be found in three places. First, those sources discussmg Yang Nai-wu's relations with the Yü-hang gentry prior to the commencement of his case state unequivocally that he was generally held in low esteem by his peers. ${ }^{346}$ These sources further indicate that Yang Nai-wu's arrest generated not sympathy but, if anything, an outburst of ill will and a spate of rumors. ${ }^{347}$ Second, there is no clear record that any officials from Chekiang tried to influence the outcome of the case during its first two and one-half years, when presumably such efforts would liave been more likely to succeed. Third, by implying in their memorial that Liu's error consisted of allowing himself to be duped by an illiterate peasant woman into committing all inanner of errors, the eighteen Chekiang officials seemed to be suggesting to the Throne that Liu was not well suited to his post as magistrate. ${ }^{348}$

Political influence may also liave worked to Yang Nai-wu's advantage botll in the findings of the select group of coroners assembled in Peking in January 1877 and in the February 1877 memorial of the cen-

343. Although Preston Torbert is principally concerned in his study of the early Ch'ing Imperial Household Department with questions of structure and function, our inquiries into the imperial decisionmaking process during the late Ch'ing would no doubt be greatly facilitated if we had a study for this period of the quality of P. TORBERT, THE CH'ING IMPERIAL HouSEHOLD DEPARTMENT: A Study of Its ORganization ANd Principal Functions, 1662-1796 (1977).

344. Shen Pao, Mar. 29, 1876.

345. Yü-HANG GAZETTEeR, supra note 112 , at 2.

346. See, e.g. LI Tz'U-MING, DiARY, supra note 32, at 4194-95; WRITINGS ON ADMINISTRATION, supra note 100, at 4:727-28.

347. See, e.g., Li Tz'U-MING, DiarY, supra note 32, at 4475-80; Shen Pao, Apr. 4, 1877.

348. Shen Pao, Mar. 29, 1876. 
sor Wang Hsin. ${ }^{349}$ There is no firm evidence available showing that the expert coroners' determination that Ko P'in-lien had died a natural death was politically motivated. Nonetheless, given the political circumstances of the case, the state of Ko's remains, and the nature of nineteenth-century forensic science, the unanimity of these coroners at least raises the possibility that science nay not have been their only guide. The lack of reliable biographical data for Wang Hsin precludes any conclusive statements regarding his pohtical affiliations, but his refusal to rest content with the vindication of Yang Nai-wu and his ardent plea for exceptionally severe punishments for Governor Yang Ch'ang-chün and Literary Chancellor $\mathrm{Hu}$ Jui-lan at least raise the possibility that he may have been motivated as much by national political considerations as by a desire to see justice done. ${ }^{350}$

The difficulties that undue political influence caused for the late Cl'ing criminal justice process were coinpounded by a fourth problein: the tension between Chma's central and provincial governments. As a result of this tension, essentially legal or administrative issues were often transformed into full-blown political disputes. Thus, questions raised in Peking through the obligatory review system or the ching$k$ 'ung that might in a more stable age have been resolved on their merits became tests of strength between the Throne and its governors.

The age-old tension between Peking and the provinces was particularly serious throughout much of the nineteenth century. During the half-century preceding Yang Nai-wu's case, the gradual breakdown of the government's authority in large areas of central, southeastern, soutliwestern, and nortliwestern Chma, in coinbination with other factors including overpopulation and racial discrimination, led to the outbreak of large-scale uprisings known as the T'ai-p'ing, Nien, and Moslem rebellions. ${ }^{351}$ At various times during that half-century, one or another of these popular rebel movements exercised effective control over large portions of the empire, including inost of Chekiang. After imperial army efforts to suppress the T'ai-p'ing rebels had failed, the central government turned in desperation to officials such as Tseng Kuo-fan, Tso Tsung-t'ang, and Li Hung-chang and urged them to take

349. TUNG-HUA RECORDS, supra note 32 , at 345-47.

350. Recollections from the Hua-sui-jen-sheng Chamber suggests, without offering convincing proof, that such political considerations may have been at play. CHAMBER ReCOLLECTIONS, supra note 100 , at 389 . Specifically, it treats Wang Hsin's memorials about this case as a ploy in an interregional political struggle against the two Hunanese, Yang Ch'ang-chun and Hu Jui-lan. Id. Indeed, it further suggests that these memorials were prompted by the censor Pien Pao-ch'ulan (who, it intimates, was related to Wang Hsin by marriage). Id.

351. See generally Chiang Slang-tseh, The Nien Rebellion (1954); Chien Yu-wen, The T'ai-P'INg Revolutionary Movement (1973); Chu Wen-DJang, The Moslem Rebellion IN Northwest China 1862-1878 (1966); Kuhn, The T'ai-p'ing Rebellion, in 10 The Cambridge History OF CHINA, supra note 335, at 264. 
whatever steps were necessary to restore order. ${ }^{352}$ Aware of the hopelessly corrupt and ineffectual nature of the imperial army, Tseng, Tso, and $\mathrm{Li}$ formed private armies manned by their fellow provimcials. Over a number of years these armies were able, with military assistance from certain Western governments and individuals, to squelch the T'aip'ing.

The cure for the T'ai-p'ing Rebellion, however, proved nearly as deadly as the disease. Although Tseng, Tso and $\mathrm{Li}$ were all Confucian generals loyal to the Throne, ${ }^{353}$ the creation and success of regionally based private armies served only to accelerate further the decline of the central government's strength and authority. ${ }^{354}$ In the years following the suppression of the T'ai-p'ing, Nien, and Moslein rebels, the central government's failure fully to reassert its authority and the emergence from these private armies of regional leaders less dedicated to Confucian values and the Throne contributed even more to the diffusion of power from Peking to the provinces. ${ }^{355}$ The central government's authority was further impaired both by its inability to halt the West's extraterritorial encroachments and by the scandal surrounding the Empress Dowager Tz'u-hsi's inanipulation of the imperial succession.

In its later phases, the case of Yang Nai-wu appears to have becoine embroiled in the political tension between the central and provincial governments. Governor Yang Ch'ang-chün was in many respects typical of the generation of men who assumed the einpire's governorships during the T'ung-chih and early Kuang-hsü reigns. Having bypassed the examination system, with its heavy dose of Confucian indoctrimation, and having received the Chekiang Governorship through his military and political exertions, Yang Ch'ang-chün exhibited greater independence from the Throne than a inodel Confucian official would have. The case of Yang Nai-wu provides at least two examples. First, when the Throne was weighing the censor Pien Paoch'ulan's request that the case be brought to Peking, Governor Yang indicated to it his displeasure with that deliberation. ${ }^{356}$ Both Governor Yang's attitude and the terms in which he chose to express it suggest

352. Liu Kwang-ching, Restoration, supra note 335, at 410, 435-36; A. Hsieh, Tseng Kuo-fan: A Nineteenth-Century Confucian General 66-165 (1975) (unpublished doctoral dissertation in Sterling Memorial Library, Yale University).

353. J. Fairbank, E. Reischauer \& A. Craig, East Asia: Transformation and TradiTION 565-66 (1978).

354. S. Spector, Li Hung-chang and the Hual ARmy: A Study in Nineteenth-CenTURY CHINESE REgIONALISM passim (1964).

355. This is not to take issue with Professor Liu's findings that the central government reasserted some measure of control over many official appointunents during the T'ung-chih Restoration period, see supra note 335, but rather to suggest that viewed in a longer time frame, this resurgence of the central government's authority was a limited phenounenon.

356. Li Tz'U-MING, DiaRY, supra note 32, at 4498-99; Shen Pao, Mar. 7, 1876. 
not only that he viewed the Throne's legitimate concern about judicial administration in Chekiang as solnething of an unwarranted intrusion, but that he was hardly overcome with the awe that Confucian officials were supposed to experience when addressing their Einperor.

The tensions between the Governor of Chekiang and the central government were further evidenced when the Throne decided to have the case brought to Peking and ordered Yang Ch'ang-chün to arrange for the safe and expeditious passage of all necessary individuals and documents to the capital. ${ }^{357}$ Governor Yang coinphed with this order only after a lengthy period of open defiance and obstruction. Judging from his behavior and from the comments of Wang Hsin and others, it seems that the Governor's resistance was prompted less by a desire to cover up his underlings' errors than by his distinct displeasure with attempts of the central government to assert genuine control over provincial matters. ${ }^{358}$

Governor Yang's actions were not the only indications that the case concerned more than the plight of the two individuals charged with murder or even that of the inagistrate who initially tried them. The meinorials submitted by the censors Pien Pao-ch'üan and Wang $\mathrm{Hsm}^{359}$ clearly stated that the case raised the issue of relations between the central and provincial governments. In his meinorial, ${ }^{360}$ Pien Paoch'ulan did not restrict his criticism to Yang Ch'ang-chün and Hu Juilan. Instead, he argued that Hu's conclusion that Governor Yang had handled the case properly was but one example of the devolution of power froin the central government to the provinces and of its corrosive impact upon the obligatory review system, the ching-k'ung procedure, and the formal criminal justice process generally. Wang Hsin's inemorial $^{361}$ was even more focused than Pien's upon the authority of the central government. But for the recent diffusion of power to the provinces and the presence of a child Emperor in Peking, he argued, Yang Ch'ang-chün, $\mathrm{Hu}$ Jui-lan, and others like thein would never have assumed such cavalier attitudes toward the Throne. Similar attitudes had already done inuch to undermine the integrity of the legal system and disrupt the proper workings of the einpire. Therefore, it was important to make an example of Yang and $\mathrm{Hu}$ so that in the future, provimcial officials would better appreciate their correct roles. The Throne in effect endorsed the positions advanced in Wang Hsin's nemorial by for-

357. TUNG-HUA RECORDS, supra note 32 , at 165-66.

358. Id. at $345-47$.

359. Id.

360. Pien Pao-ch'tlan's memorial is discussed supra in text accompanying notes 213-15.

361. Wang Hsin's memorial is discussed supra in text accompanying notes 254-57. 
warding it to the Board of Punishments and by ultimately approving the Board's recommendation that Yang and $\mathrm{Hu}$ be punished.

As the above discussion indicates, serious probleins tended to distort, if not undermine, three of the four formal checks designed to insure the proper functioning of the formal criminal justice process. For exainple, in Yang Nai-wu's case, Magistrate Liu did not follow the elaborate rules regulating the exercise of his official responsibilities. Nor did the obligatory review system or the ching-k'ung appellate procedure fully succeed in uncovering the errors committed at the district level. One such check, however, did function as intended. By subınitting ineinorials attacking errors committed by officials and by prodding the Throne to reverse its earlier decisions not to pursue the case vigorously, the censors Wang Shu-jui, Pien Pao-ch'ủan, and Wang Hsin fulfilled the Censorate's traditional tasks of overseeing officialdoin and reinonstrating with the Einperor. Indeed, in so doing they not only sought to resolve correctly this particular case, but they also suggested general improveinents for the late imperial criminal justice process.

Unfortunately, as Charles Hucker, the leading modern authority on the Censorate, has indicated, neither Chinese nor Western scholars have yet produced a definitive study of the Ch'ing Censorate. Accordingly, we cannot definitively evaluate the Censorate and related supervisory bodies during the nineteenth century. ${ }^{362}$ Although nineteenthand early twentieth-century observers as different as W.H. Medhurst ${ }^{363}$ and Sun Yat-sen ${ }^{364}$ praised the Censorate, the work of Kao I-han and others indicates that during the Ch'ing, the Censorate did not have as active and independent a presence outside the capital as in earlier dynasties. ${ }^{365}$ Instead, Kao suggests that the Ch'ing made up for a diminished provincial censorial presence by relying upon line officials in the regular bureaucracy to perforn traditional censorial supervisory functions in addition to their routine responsibilities. ${ }^{366}$ This arrangement could easily have produced difficulties of the type already discussed above with respect to the monitoring by higher officials of appeals froin their subordinates' decisions. ${ }^{367}$ For now, we simply do not know whether any ill effects of diminished provimcial censorial presence were

362. C. HUCKER, supra note 304, at 3-4. In addition to this excellent book-length study of the Censorate, see Hucker, Confucianism and the Censorial System, in CoNFuCiANISM IN ACTION 182 (D. Nivison \& A. Wright eds. 1959) (a discussion of the censorial system with special reference to the Ming Dynasty (1368-1644)).

363. W. Medhurst, China: Its State and Prospects 130 (1838).

364. Sun Yat-sen, San Min Chu I [The Three Principles of the People] 356-57 (F. Price trans. \& L. Chen ed. 1943).

365. KAO I-HAN, Evolution, supra note 307, at 77-89.

366. Id.

367. See supra text accompanying notes 309-27. 
mitigated by active censors in the imperial capital, such as the three who played prominent roles in this case, or by other supervisory personnel, such as circuit intendants. ${ }^{368}$

If the case of Yang Nai-wu and Hsiao-pai-ts'ai points out shortcomings of those checks built into the formal criminal justice process, it also provides one of the first illustrations of a new type of informal nongovernmental check. The articles that the Shen Pao ran on this case represented a radical departure from tradition, both in their general goal and in their particular substantive commentary upon this case and the formal criminal justice process. The unprecedented aim of these articles was to influence officials by appealing through "mass media" to "public opinion," albeit the opinion of a public coinposed almost exclusively of officials and other members of the elite. Although daily journals had been published by the imperial government from the time of the Sung dynasty (960-1279 A.D.), it was not until the midnineteenth-century advent of newspapers such as the Shen Pao that the Chinese press undertook to criticize and influence governmental affairs through independent criticism. ${ }^{369}$

The substance of the Shen Pao's cominents on the case and on the crimimal justice process also represented a departure from tradition. The paper not only accused officials of colluding with each other and breaking the law, but also called into question the very soundness of certain aspects of the formal criminal justice process. ${ }^{370}$ Indeed, its editors went so far as to suggest that the abuses evident in Yang Nai-wu's trial were endemic. ${ }^{371}$ The Chinese criminal justice process compared poorly with that of Western nations, they suggested. Therefore, the foreigners' insistence upon the extraterritorial application of their criminal law ${ }^{372}$ may have been soinewhat warranted and not a inere facade through which to take advantage of China. ${ }^{373}$ Examining the imperial criminal justice process in light of their understanding of Western legal

368. Professor Fairbank is of the opinion that by the late Ch'ing, the Censorate focused more upon its surveillance tasks than its remonstrance responsibilities. Fairbank, Introduction to 10 The CAMBridge History of China, supra note 335, at 25. Professor Metzger, on the other hand, is of the opinion that "even in the realm of surveillance, offices besides the Censorate [for example, that of the circuit intendant] played a major role, especially outside the capital." T. METzGER, supra note 28 , at 269.

369. E.P. Link, Mandarin Ducks and Butterflies: Popular Fiction in Early Twentieth-Century ChINESE Cities 97-103 (1981). Undoubtedly, the fact that the Shen Pao and similar newspapers were published in the mternational settleinent of Shanghai and in Hong Kong, and were thus beyond the reach of Ch'ing authorities, greatly facilitated their ontspokenness.

370. Such criticisms-as well as some of the more lurid accounts of Yang Nai-wu's and Hsiao-pai-ts'ai's travails - inay also have been proinpted by a general effort to boost circulation in the mid-1870's. See id. at 97-98; infra Appendix $A$.

371. Shen Pao, May 4, 1877.

372. For a discussion of extraterritoriality, see supra note 45.

373. Shen Pao, Sept. 17, 1875. 
practices, the editors of the Shen Pao concluded that serious shortcomings of the Chinese process included the use of torture to extract confessions, ${ }^{374}$ the absence of laws providing individuals accused of crimes with the opportunity to confront witnesses offering testimony against them, ${ }^{375}$ and the fact that Chinese officials with judicial responsibilities lacked legal training: ${ }^{376}$ Accordingly, the editors urged that those offcials in Peking responsible for the formal criminal process take steps to correct these specific deficiencies and to "modernize" the process generally. These steps wonld not only speed the end of extraterritoriahty but would also foster the huniane and fair administration of law in the Middle Kingdoin. ${ }^{377}$

\section{CONCLUDING THOUGHTS}

The case of Yang Nai-wu and Hsiao-pai-ts'ai does not answer all the questions that one might have about the late imperial criminal justice process, nor could it. It does, however, aid efforts to evaluate foriner and current portrayals of that process and to frame questions for future research.

At a minimuin, the case should lead us to question the view that in the absence of certain restraints and practices familiar to us in the West (most notably, a separation of powers, procedural due process, and an independent legal profession), the imperial criminal justice process was little inore than a vehicle for the consolidation of state control by the district magistrate. ${ }^{378}$ The case of Yang Nai-wu and Hsiao-pai-ts'ai clearly illustrates that the imperial criminal justice process encompassed a broad range of sophisticated procedural and administrative measures designed to convict the guilty and acquit the innocent, even at the expense of magistrates and other inembers of Confucian officialdom. ${ }^{379}$ The ch'u-fen tse-li and selected laws were at least partially intended to foster the attaininent of such results in criminal cases. They performed this function by sharply circumscribing the discretion of magistrates (and, for that matter, every official of the imperial state) in favor of uniform, comprehensive rules governing all aspects of criminal

374. Id.

375. Id:; see supra note 203.

376. Id.

377. Id. The editors of the Shen Pao were not alone in expressing this sentiment. Kuo Sungtao and others advocated the reform of China's law both to help brimg an end to extraterritoriality and to promote the welfare of the Chinese people. J. CH'EN, supra note 17, at 325-26; Hao Yenp'ing \& Erh-min Wang, Changing Chinese Views of Western Relations 1840-1895, in 11 THE CAMBRIDGe History OF ChINA, LATE Ch'ING, 1800-1911, PART II, at 142, 195 (J. Fairbank \& D. Twitchett eds. 1980).

378. See, e.g., J. Cohen, Criminal Process, supra note 11, at 5-7.

379. See supra notes 260-62, 267-75, 291-305 and accompanying text. 
investigation, interrogation, and trial. ${ }^{380}$ Furthermore, appellate and supervisory measures could be brought to bear on official behavior by independent oversight personnel im the Censorate and related entities, ${ }^{381}$ by persons utilizing the voluntary appellate procedures, ${ }^{382}$ or by higher officials through the obligatory review process. ${ }^{383}$ And, at least in theory, even the Emperor had a legally prescribed role in the effort to see that justice was done in each case: lie was required to review and pass upon virtually all death sentences, ${ }^{384}$ and his imperial bureaucracy had to include a Censorate charged with admonishing him, if necessary, in criminal inatters, among otliers. ${ }^{385}$

The presence of measures designed to facilitate the conviction of the guilty and the acquittal of the innocent through the control of official discretion does not, of course, mean that sucli results were regularly reached or that sucli discretion was always properly controlled. Unfortunately, we are not now in a position to form conclusive judgments as to liow the process worked across China throughout the late imperial period. ${ }^{386}$ Indeed, the case of Yang Nai-wu and Hsiao-paits'ai itself hardly provides us witls a single answer. For although the case graphically illustrates many serious practical imperfections in the process, particularly witl respect to its inability to deter magisterial deviations from the ch'u-fen tse-li and related laws, ${ }^{387}$ at least in this celebrated instance two seemingly incorrect capital sentences were reversed and officials who acted improperly were punislied.

The case also illustrates that a range of persons in late imperial China from ordinary peasants to the Throne viewed the process as liaving the capability of dispensing justice. Thus, we ouglit not to assume that the process was then seen only as a tool of state control little concerned with the attainment of individual justice. ${ }^{388}$ Whatever other

380. T. METZGER, supra note 28, at 247-75; see also supra notes $292-94$ and accompanying text.

381. See supra text accompanying notes 303-05.

382. See supra note 184 and text accompanying notes 297-301.

383. See supra note 295 and accompanying text.

384. See supra text accompanying notes $296,300$.

385. See supra text accompanying notes 304-05.

386. See infra text accompanying notes 399-434.

387. See supra notes $307-08$ and accompanying text.

388. For a discussion of this assumption, see supra text accoinpanying notes 89-97. In an account of his tenure as British consul in the North China city of Weihaiwei during the late 19th century, Reginald Johnston inadvertently provides evidence suggesting that the stereotype of a population fearful of fornal courts may not have been wholly warranted. R. JOHNSTON, LION AND DRAGON IN NORTHERN ChINA 195-210 (1910). While serving as British consul in Weihaiwei, Johnston observed that the Chinese availed themselves of the opportunity to seek redress through British courts with bittle of their reputed hesitancy to use fornal legal processes. This was particularly true of Chinese women, who would have had difficulties in vindicating themselves through either the formal Chinese criminal jnstice process or such informal processes as mediation. Id. Michael Moser's research on Taiwan also indicates that during the late $\mathrm{Ch}^{\prime}$ ing at least in 
political or economic factors may have been at play, the work of Yang $\mathrm{Nai}-\mathrm{wu}$ and $\mathrm{Cli}^{\prime}$ en Chu-shan as informal legal advisors of Yü-hang residents, ${ }^{389}$ Yang Nai-wu's utilization of the ching-k'ung procedure in his own case, ${ }^{390}$ the decision of the Chekiang officials led by Wang Shup'ing to take up Yang Nai-wu's case, ${ }^{391}$ the complaints of various officials about the breakdown of the ching-k'ung procedure, ${ }^{392}$ the persistent efforts of Wang Hsin and his fellow censors to influence the case, ${ }^{393}$ and the involvement of the Shen $\mathrm{PaO}^{394}$ all evidence some belief that the process, although imperfect, was not a inere facade.

The Throne itself seems to have seen the process as having some vitality in practice. Throughout the case it took steps, albeit with some prodding, to ensure that a decision challenged through utilization of the ching-k'ung be reviewed and that even important officials adhere to administrative and procedural rules. ${ }^{395}$ Further, in 1882, the Throne attempted to eliminate deficiencies in the process by amending the ching-k'ung procedure so that appeals involving serious crimes (including capital crimes) would be far more rigorously and fairly reviewed. ${ }^{396}$

Clearly, mucl more work must be done before we can begin to evaluate low well the formal criminal justice process in late imperial China actually worked. Until such work is done, however, we should not rest content with the assumptions that the process was incapable of doing more than vesting magistrates witli unbridled power and was viewed by the populace as liaving little to do witl justice.

Although the case of Yang Nai-wu and Hsiao-pai-ts'ai leads us to question certain of the primcipal rationales for characterizing the formal criminal justice process as little more than a vehicle of state control, it also raises the possibility of anotler, more subtle justification for so characterizing the process. It could be argued that the process' elaborate procedural and administrative measures were indeed designed to circumscribe the discretion of district magistrates and their provincial superiors, but with the ultimate goal of consolidating power in the liands of the central government. ${ }^{397}$ Viewed in this light, the generally evidenced concern witl the attainment of individual justice might be

\footnotetext{
that island province, there may not have been as much ideological opposition to litigation as is often suggested. M. Moser, Law and Social Change in a Chinese Community: A Case StUdY From RuRal TAIWAN 176-83 (1982).

389. See supra notes $108,110-12,141$ and accompanymg text.

390. See supra notes 186-88, 192-94 and accompanying text.

391. See supra notes 231-34 and accompanying text.

392. See supra notes 214-15, 322-31 and accompanying text.

393. See supra notes 204-06, 214-16, 254-57, 322-23 and accompanying text.

394. See supra notes $369-77$ and accompanying text.

395. See supra notes $206,216,234-35,251,284$ and accoinpanying text.

396. See supra text accompanying notes 315-32.

397. For a discussion of how procedural regularity can serve to reinforce state control in a
} 
explained as an unintended by-product of the larger effort to coalesce power centrally, as a short-term tactical device in the struggle against opponents whose strength lay at the provincial level, or as a carefully chosen instrument for impressing upon the populace the legitimacy and control of the central government.

The case itself does not enable us to evaluate definitively this justification for characterizing the criminal justice process as a tool of state control at most instrumentally concerned with individual justice. It may be that the Chekiang officials in Peking who involved themselves in the case, other Board officials who took an interest in it, and, to a lesser extent, even the imperial censors were inotivated more by postT'ai-p'mg ${ }^{398}$ struggles between central and provmcial authorities than by any intrinsic interest in imsurimg that the accused be treated justly. Conversely, one could argue that these individuals were primarily interested in seeing justice done in this particular case, but believed that they could best inake their point by emphasizing broader problems in the Throne's efforts to supervise the criminal justice process and to consolidate power generally. Moreover, at least one other key factor-the role of the Shen Pao, and particularly its substantive comments on the case-calmot readily be explained in terms of the power struggle between the central government and the provinces.

Before we can arrive at definitive judgments about the formal criminal justice process in late imperial China, we unust greatly enhance our understanding of it at three different levels. First, we inust endeavor to elaborate our picture of the various components of the process, their intended function and their actual operation. Second, we must further explore its larger historical, philosophical, political, social, and economic contexts. Finally, we must sharpen our awareness of the enornous difficulties inherent in such cross-cultural judgments.

At the level of the intended function and actual operation of the imperial criminal process, we need to explore topics such as the following: the prevalence, training, and role of sung-kun and other unofficial legal advisors; ${ }^{399}$ the degree to which magistrates and higher level officials were able on their own and through their assistants to acquire a serious working understanding of the law; ${ }^{400}$ the reasons for official disdain of sung-kun and particularly the extent to which officials with legal responsibilities (from legal secretaries to the Board of Punishınents'

different setting, see Hay, Property, Authority and Criminal Law, in Albion's Fatal Tree: Crime AND Society IN Eighteenth-CentuRY England 17, 58-59 (D. Hay ed. 1975).

398. For more on the chaos generated by the T'ai-p'ing uprising and other mid-century events, see supra text accompanying notes 351-55.

399. See supra notes $108,135,308$.

400. See supra notes 70,308 and accompanying text. 
members) sought to "monopolize" access to the law's meanmg;"401 the uses and abuses of torture, ${ }^{402}$ the extent to which convictions were entered without confessions; ${ }^{403}$ the consistency of sentences given throughout China; the extent to which imdividuals were punished for the crimes of others because of family or pao-chia relationships; ${ }^{404}$ the frequency with which errors committed at lower levels were subsequently corrected on review or on appeal; ${ }^{405}$ the extent to which officials carried out executions without first seeking higher approval and the degree to which such actions were subsequently scrutinized by the central government; ${ }^{406}$ the impact of the requirement that magistrates designate a simgle law im passimg judgment; ${ }^{407}$ the ease with which wayward officials were able to mvoke their immunity or otherwise avoid punishinent; ${ }^{408}$ the background of persons utilizing the shang-k'ung procedure and the success of their petitions; ${ }^{409}$ the extent to which those im the imperial bureaucracy controlling "legislative" draftimg viewed the shang-k'ung as a means through which individuals could vindicate theinselves; ${ }^{410}$ the degree to which prefects and higher level provincial officials carried out the de novo imvestigations called for by law; ${ }^{411}$ the organization and effectiveness of the Censorate, particularly in the provimces; ${ }^{412}$ the relationship of the provincial governors and the Board of Pumshinents; ${ }^{413}$ the utilization of coroners and other such experts in the review of appeals; ${ }^{414}$ the frequency of special commissions and the procedures for appointing their members; ${ }^{415}$ the full scope of the role

401. At first blush, the notion that magistrates and others charged with legal responsibilities may have been interested in monopolizing access to the law seems an interpolation of Western concerns upon the Chinese scene. This mitial reaction, however, derives largely from the stereotypes of the inagistrate as knowing and caring little about the law and of the sung-kun as little better than an unschooled charlatan. If these stereotypes need modification (as may be the case), the possibihity that magistrates and sung-kun were interested in monopolizing the law takes on an added importance. I am indebted to Professor Martim Shapiro for alerting ine to this question first through the essay on traditional Chinese law in his book COURTS: A COMPARATIVE AND POLIT1CAL ANALYSIS (1981) and then in correspondence.

402. See supra notes 78, 151 and accompanying text; see also text accompanying notes 293 , 308.

403. As indicated supra in note 161 , technically the law did not require that a defendant make a confession before conviction.

404. See stupra note 85 and accompanying text.

405. See supra note 308 and accompanymg text.

406. See supra note 296 and accompanying text.

407. See supra note 308.

408. See supra note 262 and accompanying text.

409. See supra notes 184,320 and accompanying text.

410. Id.

411. See supra notes 163-64 and accompanying text; see also text accompanying note 309.

412. See supra notes $362-68$ and accompanying text.

413. See supra text accompanying notes 238-40, 254-56, 273.

414. See supra text accompanying notes $241-47$.

415. See supra notes 206,320 and accompanying text. 
provided for the Emperor in the formal criminal justice process; ${ }^{416}$ the manner in which various Emperors discharged their responsibilities; ${ }^{417}$ the involvement of newspapers such as the Shen Pao in other cases, and their overall concern with the criminal justice process; ${ }^{418}$ and the impact of legally tramed Westerners resident in China. ${ }^{49}$

Questions about the broader contexts within which the formal criminal justice process operated are no less vital. For example, Confucian doctrime did not posit a relationship of equality between ruler and ruled, at least with respect to issues of governance. ${ }^{420}$ To the contrary, the Emperor and those who exercised power in his name occupied a position relative to the populace akin to that of parents to their children. ${ }^{421}$ The district magistrate, who was for most Chinese the einbodiment of imperial authority, was known as the fu-mu kuan (literally, "father and mother official"422), while imperial edicts and other official statements often took on a parental tone. ${ }^{423}$ Did this notion impose a fiduciary-like obligation upon the Einperor and his officials to exercise a restraint beyond that found in the formal law governing the criminal justice process? Or did it inerely underscore in the minds of the powerful the insignificance of the powerless? ${ }^{424}$

To take another example, scholars have assumed that the Chinese populace typically viewed the formal criminal justice process as proinising nothing but trouble and therefore were fearful of it. ${ }^{425}$ The case of Yang Nai-wu clearly illustrates what may have given rise to such anxieties, ${ }^{426}$ but also reveals expectations on the part of many that the process could be just. ${ }^{427}$ Were these expectations an aberration attrib-

416. See supra notes 296, 300 and accompanying text; see also Shiga, Criminal Procedure (I), supra note 30 , at $15,16$.

417. See supra note 300.

418. See supra notes $369-77$ and accompanying text.

419. See infra note $\mathbf{4 2 8}$ and accompanying text. To date relatively little has been written about the activity of legally trained Westerners in China during the late imperial period. One longs for a study in this area of the quality of S. Cochran, BIG Business in CHINA (1980). 64.

420. See, e.g., Wang K'ang-nien on Democracy, in CHINA's Response, supra note 47, at 161-

421. See, e.g., L. PYE, supra note 17 , at 61 .

422. Sce J. WATT, supra note 29 , at 85-87.

423. See, e.g., the discussion of the Yung-cheng Einperor's rhetoric in S. WU, Communication and Imperial Control in China: Evolution of the Palace Memorial System 16931735, at 73-75 (1970); see also J. SPENCE, supra note 300, passim.

424. Drawing upon Tornnies and Weber, Eugene Kamenka and Alice Tay suggest "the emperor's seemingly arbitrary exercise of judicial and police powers [could be] taken to be part of his parental function." Kamenka \& Tay, supra note 16, at 23; see also L. STOVER, supra note 17, at 89-91.

425. See supra text accompanying notes 89-97.

426. One example is the concern, apparently justified, of the druggist alleged to have sold the arsenic to Yang Nai-wu. See supra text accompanying notes 170-75, 239.

427. See supra text accompanying notes 389-96. 
utable to the unusual nature of late imperial China and in particular to the havens from Ch'ing jurisdiction provided by the Western presence in China? ${ }^{428}$ Or, alternatively, in eras other than the late Ch'ing, ${ }^{429}$ were comparable expectations as or even more prevalent? And how did these expectations shape the willingness of the populace to utilize the formal criminal justice process? ${ }^{430}$

Finally, we must address a third tier of imquiries: what are appropriate standards for evaluatimg the crimmal justice process of a society removed from our own both culturally and temporally? Simply stated, should we view convictions of the guilty and acquittals of the innocent in late Ch'mg China as less than fully just because they were attained through a process very different from our own? Are the results of the Chinese process-im which the individual was relegated to a relatively passive role and a single official was charged with promptly ferreting out the truth-any less just than the results of the latter process-in which the individual is given a greater opportunity to present his version of the truth, but faced with a concomitantly greater responsibility to see that his version comes before the adjudicator? ${ }^{431}$ Should we say that the late imperial Chinese process was more interested in justice than is the modern American criminal process because our process' stated objective of "msuring the respect of the dignity of the individual" may result im guilty persons going free rather than being forced to confess? ${ }^{432}$ Or, should we conclude that the Chinese process was less just because of its concern that all crimes be resolved within pre-

428. The importance of the sanctuary provided by treaty port areas beyond Ch'ing jurisdiction is emphasized in M. RANKIN, EARLY CHINESE RevolutionarIES: RADICAL INTELLECTUALS in Shanghai ANd Chekiang, 1902-1911, at 48-50 (1971); and E.P. Link, supra note 369, at 79-80.

429. Even if the late Ch'ing era has been the chief focus of Western scholars because of its relative accessibility and contact with the West, P. CoHen, Discovering History in China: american Historical Writing on the Recent Chinese Past (1984), it was in many respects the nadir of more than 2000 years of imperial Chinese history, B. SCHWARTZ, IN SEARCH OF Wealth AND Power: Yen Fu AND the West 1-19 (1964). Professor Zhang Guohua is of the opinion that this period was also a low point in Chinese legal history. See Zhang Guohua, Chinese Legal Thought, supra note 14, at 5.

430. At present, we do not know the degree to which the Chinese populace adhered to those provisions of Ch'ing law requiring all disputes, whether criminal or civil in nature, (save for those concerning "petty matters") to be brought to the magistrate rather than settled through alternate means, such as inediation by clan or village elders. See Cohen, Chinese Mediation, supra note 16, at 1211.

431. The official's fiduciary-like obligation to ferret out the truth may help explain why the $c h$ 'u-fen tse-li required punishinent of official misfeasance as well as official malfeasance. CH'ING CODE, supra note 76, \$\$ 7-8; see also In re Hsii Chung-wei (unpublished translation by Fu-mei Chang Chen and others in the Harvard East Asian Legal Studies Group of a Chinese case decided in 1780), in 1 CHINESE LAw II, C, 109 (W. Alford 2d ed. 1984) (unpublished text available at the U.C.L.A. Law Library). In that case, a nearsighted inagistrate was punished for failing to detect a small head wound on a corpse and so erroneously accepting a corrupt coroner's deterinination that death was attributable to suicide by poison.

432. Kadish, Methodology and Criteria in Due Process Adjudication-A Survey and Criticism, 
ordained time periods, especially if we subsequently determine that this concern had inore to do with the inaintenance of communal harmony than the vindication of the individual? There are no ready answers for these normative questions, but we inust thoughtfully consider thein as we seek to make sense of the late imperial formal criminal justice process.

The enterprise that awaits scholars of that process is vast, but that vastness need not be daunting. To the contrary, with archives and libraries in the PRC becoming more accessible to Western scholars ${ }^{433}$ and with scholars in the PRC beginning to have increased opportunities to turn their attention to legal history, ${ }^{434}$ this is an exciting and important time. We are now in a position to examine, with a fresh eye, China's rich but much neglected legal history. In so doing, we can begin to ascertain the degree, if any, to which images of China's legal history that have long dominated our thinking warrant retention. Only in that way will we be able to understand China's legal heritage and, through that, her present and ambitious projected undertakings in the field of law.

66 YALE L.J. 319 (1957). For a cogent discussion of the values underlying concern in the United States for the protection of the right to procedural due process, see id. at 346-49.

433. See, e.g., Humanistic and Soclal Science Research in China: Recent History and Future Prospects (A. Thurston \& J. Parker eds. 1980); Ming AND QING Historical. Studies in the People's Republic of China (F. Wakeman ed. 1980).

434. Legal history is now an integral part of the curriculum of all leading Chinese law schools. See, e.g., Wuhan Daxue Jiaoxue Zhidashu 1981-1983 [The Catalogue of Wuhan UnIVersity]; R. Edwards \& W. Alford, Summary Report on the Schools of Law at Beijing University, Wuhan University, East China School of Political Science and Law, Jilin University, and the People's University (1982) (unpublished report for the Ford Foundation). Articles on legal history appear in Chinese law journals and legal newspapers far more frequently than they do in the United States. 


\section{APPENDIX A}

In the course of reconstructing and analyzing the case of Yang Nai-wu and Hsiao-pai-ts'ai, it has been necessary to refer to a wide variety of inaterials, ranging from detailed edicts issued in the name of a five-year-old Emperor, to quasi-official legal reports, to the libretto of a Peking opera. Although the origmal docuinentation is probably as extensive as that for any case in imperial Chinese history, no contemporaneous or other source provides a comprehensive picture of the case and its significance. Six primary sources, however, when taken together and suppleniented with a range of other primary and secondary nraterials, enable one to reconstruct nuch of the case.

The nost comprehensive account of the case is found in the KUANG-HSÜ CH'AO TUNG-HUA LU [RECORDS FROM WithIN THE TUNG-Hua Gate FOR THE KuANG-Hsü REIGN] (Chu Shou-p'eng ed. 1958) (Beijing reprint). The twelfth in a series of quasi-official histories compiled during the Ch'mg by scholars employed by the State Historiographer's Office, this work was modeled after the first Tung-hua Records, which was compiled by the renowned historian Chiang Liang-. ch'i between 1765 and 1779. The editor of the Tung-hua Records for the Kuang-hsü reign, Chu Shou-p'eng, included in his work virtually all edicts issued in the Emperor's name, as well as most important memorials submitted to the Throne during that reign. Because it was compiled by a skilled historian with access to official records and because it is so comprehensive, the Tung-hua Records is considered, along with the TA-Ch'ING Te-Tsung ChINg Huang-TI SHIH LU [The VeriTABLE RECORDS OF THE KUANG-HSÜ EMPEROR] (Taipei reprint 1964), to be one of the two best sources for the history of the Kuang-hsü reign. Indeed, many scholars feel that the Tung-hua Records is the better source because it contains a greater number of niemorials, which generally provide more detailed infornation than do edicts. Nonetheless, the Tung-hua Records is not without its drawbacks. Chief among them is the fact that the most comprehensive meniorials about the case that it contains were written by officials who were mvolved in the case. A second problem is that because it consists exclusively of official documents, the Tung-hua Records tends to reflect a pro-Confucian, pro-imperial bias and to ignore infornation that might not ordinarily make its way into communications between the Emperor and his officials. Two further difficulties are that $\mathrm{Chu}$ Shou-p'eng failed to mclude every memorial relating to the case and edited certain of those he did include.

A second major source is the HsIN-TSENG HsING-AN HUI-LAN [A New Supplement to the Conspectus of Penal Cases] (P'an Wenfang \& Hsü Chien-ch'üan eds. 1886). The Hsing-an Hui-lan [The Conspectus of Penal Cases] and its three supplements (of which this is the 
second) are considered by Professors Derk Bodde and Clarence Morris to be the "largest . . ., broadest . . ., and best classified" of Ch'ing dynasty collections of cases, (or casebooks, as they were referred to contemporaneously). D. BODDE \& C. MORRIS, LAW IN IMPERIAL ChINA 146 (1967). A New Supplement to the Conspectus contains more than 250 important cases. Neither the Board of Pumishments nor any other body published regular official accounts of cases; for this reason individuals such as P'an and Hsü were allowed to draw upon materials from the archives of the Board of Punishments in order to assemble collections of the highlights of cases embodymg key precedents and illustratimg significant legal principles. These casebooks were widely circulated among officials charged with judicial duties. The case of Yang Nai-wu and Hsiao-pai-ts'ai is included in a section of $A$ New Supplement to the Conspectus devoted to official misconduct. The specific offense under which the case is identified is that of failing to carry out an accurate inspection of a corpse-chien-yen shih-shang pu $i$ shih. (The law pertaining to this crime is stated and discussed in HsÜEH YÜNSHENG, TU-LI T'SUN-I [ThOUghtS ABOUT UNCERTAIN MatTERS Gleaned While Perusing the Substatutes] 412:00 (Huang Tsimghua ed. 1970) (Taipei reprint), translated in TA Ts'ING LEU LEE [THE CodE OF THE GREAT Ch'ING DYNaSty] § 412 (G. Staunton trans. 1966) (Taipei reprint) and in MANUEL DE CODE Chinols 722-23 (G. Boulais trans. 1923) (Taipei reprint).) The account of the case in $A$ New Supplement to the Conspectus provides the most accurate and complete listing of the various transgressions committed by officials trying the case but offers little inforination about other aspects of the case.

Diaries kept by the officials Weng T'ung-ho and Li Tz'u-ıning are the third and fourtl major sources for the case. Weng T'ung-lio was a major official of the late Ch'ing whose various posts included imperial tutor, Grand Councillor, President of the Boards of Punishments, Works, and Revenue, President of the Censorate, and Vice-President of the Boards of Punishments and Revenue. His diary, the WENG T'UNGHo JiH-CHI [THE DIARY OF WeNG T'UNG-HO] (Chao Chung-fu ed. 1960) (Taipei reprint) spans the years 1858 to 1904 and is widely considered to be one of the most valuable and accurate sources for that period. Eminent Chinese of the Ch'ing Period 861 (A. Hummel ed. 1964) (Taipei reprint). Those portions of the diary devoted to the case of Yang Nai-wu and Hsiao-pai-ts'ai contain detailed inforination about debates withm the Board of Punishments that are covered briefly, if at all, in the other sources. Unfortunately, Weng was able to describe the Board's deliberations because he was also a participant in the struggle that took place in the capital over this case. See supra text 
accompanymg notes $218-27$. Therefore, despite the esteem in which his diary has been held, the author's possible bias must be kept in mind.

$\mathrm{Li}$ Tz'u-ming served successively as a department director in the Board of Works and as a censor during the late Ch'ing. His diary, the YÜEH-MAN T'ANG JiH-CHI [DIARY OF THE YÜEH-MAN HALL] covers the years 1863 to 1888 and is considered a fine primary source by Arthur Hummel, among others. EMINENT CHINESE OF THE CH'ING PERIOD, supra, at 493. It is not, however, as well regarded as Weng's diary because $\mathrm{Li}$ tends to mclude unsubstantiated accounts of events he did not witness. Li's account of this case mcludes many unconfirmed, second-hand descriptions, particularly of the case's early history. One must also take into account the fact that $\mathrm{Li}$ was a native of Chekiang, as provincial loyalties proved to be important factors in the case. In spite of these difficulties, his diary is useful, both for its breadth of imformation and for the many key memorials and edicts it includes.

The Shen Pao (also romanized as the Shun Pao) is the fifth major source for the case. Prior to the late imperial period, Chinese newspapers were of three types: official gazettes pubhshing court and other government documents, unofficial gazettes reproducing such documents, and sporadic handbills (hsin-wen chih) put out by printing shops. E.P. LiNK, Mandarin Ducks and Butterflies: Popular Fiction In Early Twentieth-Century ChInese Cities 95 (1981). The Shen Pao was founded in 1872 by the British merchant Ernest Majors in the foreign settlement in Shanghai, which was soon to become the leading center of the new Western-style journahsm. Although modeled after Western newspapers and imfluenced by Western commercial interests, the Shen Pao was edited by Chinese and had, as Roswell Britton has put it, "no more ahen aspect than was warranted by the tastes of Chinese readers who were subject to the alien influences of the growing port city." R. Britton, The Chinese Periodical Press 1800-1912, at 63 (1933). Able to attract some of the finest Chinese journalists of the day, mcluding Ch'ien Cheng and Huang Hsieh-hsüan, and later, Wang T'ao, the Shen Pao overcame poor sales in its early years to become a leading paper, particularly among well-to-do Chinese families. E.P. LINK, supra, at 97-98. The paper's coverage of the early stages of the case of Yang Nai-wu was sporadic, but by the start of the Kuang-hsü reign, the Shen Pao had taken an active, if partisan, interest im the case. Its columns contam a great deal of inforination not found $m$ other sources. In view of the paper's partisanship and uneven concern for accuracy, see id. at 97 , however, one must approach this source with caution.

The sixth major source for the case is the KUANG-HSÜ CHENGyaO [IMPORTANT Policies of The Kuang-hsü ReIGN]. This unoffi- 
cial history of the 34 years of the Kuang-hsü reign (1875-1908) was compiled by Shen T'ung-sheng and published in 1909. It draws heavily upon memorials and other official docuinents drafted by high-level officials. One of these documents is an 1877 memorandum, most likely written by Board of Punishments President Tsao-pao, that summarizes the history of the case. In utilizing such documents, this work provides some data apparently not elsewhere available, but also manifests the world view of the upper ranks of late Ch'ing officialdom.

Other sources conteinporaneous with the case that are of use in reconstructing its history imclude: (1) the YÜ-HANG HsIEN-CHIH KAO [The LoCal GazetTeer For the YÜ-HANG District] (Chang Chi-an coinp. 1919); (2) the KIANGSI NIEH-SSU TING-LI HUI-PIEN [THE EsTABlished Regulations of the Kiangsi Provincial Judicial CoMMISSIONER's OFFICE] (discussed briefly supra in note 204); (3) the Ching Pao [Peking Gazette] (discussed briefly supra in note 99); and (4) various yeh-chi (informal private accounts and histories) mcluding the YÜHANG TA-YÜ CHI [A HISTORY OF THE GREAT CASE OF YÜ-HANG], Teproduced in HUA-SUI-JEN-SHENG AN CHIH-I [RECOLLECTIONS FROM THE HuA-SUI-Jen-SHeng Chamber] (Huang Chün comp. 1965) (Taipei reprint).

Numerous secondary works have also been referred to in preparing this Article. Foremost among these are a small number of articles published in Taiwan and in the PRC regarding the case. The most signiffcant of these, which was published in Taiwan, is Chao K'e-chün, Ch'ing-mou tsui hung-tung te i-jian yüan-yü [.The Most Explosive Injustice of the Late Ch'ing], 4 CHÜN-CH'IU [SPRING \& AUTUMN] 15 (1967). Chao's article is well-researched and thoughtful in its description of a number of portions of the case itself, but does not endeavor in a coinprehensive way to portray the implications of the case for a broader understanding of the late imperial criminal justice process. Shorter articles on the case published in the PRC include Zhang Mingxin, Qingmo Yang Naiwu an shimo [The Late Ch'ing Case of Yang Nai-wu from Beginning to End], 5 MINZHU YU FAZHI [DEMOCRACY \& LEGAL SYSTEM] 28 (1980) and Dao Yi, Yang Naiwu an gaosongle women shemma? [What Does the Case of Yang Nai-wu Tell Us.], 5 MinZHU YU FAZHI [DEMOCRACY \& LEgal SySTEM] 30 (1980).

Other secondary works of particular usefulness in locating and assessing the legal history of this era, in addition to the works mentioned supra in notes 14 and 28-30, are CH'ING-SHIH-KAO HsING-FA-CHIH ChU-Chieh [The ANNotated MONOGRAPH ON CRIMINAL LAW FROM THE DRAFt History of the Ching DyNASTY] (State Council, Bureau of Legal Affairs, Office for Research into Legal History comp. 1957); Chung-Kuo Fa-Chin-ShIh ShU-Mu [AN ANNotated Bibliog- 
RAPHY OF ChINESE LEgAL History] (Chang Wejen comp. 1976); MA FENG-CHEN, Ch'ING-TAI HSING-CHENG CHIH-TU YEN-CHIU Ts'ANK'Ao SHu-Mu [A Catalogue of Reference Materials for RESEARCH ON THE ADMinistrative SySTEM OF THE Ch'ing DYNASTY] (1935); and ZHONGGUO FAZHISHI CANKAO SHUMU JiENJI [AN INTRODUCTORY BIBLIOGRAPHY OF REFERENCE MATERIALS ON CHINESE LEGAL HistoRY] (Li Zuyin comp. 1968).

Among the many fine works on the domestic political climate of this period are P. COHEN, BETWEen TRADITION AND Modernity: Wang T'ao and Reform in late Ch'ing China (1974); L. Eastman, Throne and Mandarins: China's Search for a Policy DURING THE SiNo-FreNCH CONTROVERSY, 1880-1885 (1967); REForm IN NineteEnTh Century China (P. Cohen \& J. Schrecker eds. 1976); M. Wright, The Last Stand of Chinese Conservatism; The T'Ung-ChiH Restoration, 1862-1874 (1957); Wu HsianghSIANG, Wan Ch'ing Kung-T'ing ShIH-ChI [A True History of Palace Politics During the Late Ch'ing] (1961); Fairbank, Introduction to 10 The Cambridge History of China, The LATe Ch'ING, 1800-1911, PART I (J. Fairbank ed. 1978); and Liu Kwang-ching, The Ch'ing Restoration, in 10 The Cambridge History of China, The LATE Ch'ING, 1800-1911, PART I, supra, at 409. 
APPENDIX B

The Cast of Characters

Events at the District Level

The deceased: Ko P'in-lien, bean-curd seller

The accused: Yang Nai-wu, scholar

Hsiao-pai-ts'ai, (Mrs. Ko, neé Pi) peasant

Liu Hsi-t'ung, Yü-liang District Magistrate

Ch'en Chu-shan, licentiate

Yuan Te, yamen runner

Shen Ts'ai-cli'üan, watchman

Shen Hsiang, coroner

Chang Chün, District Sub-director of Studies

Liu Hai-sheng, Magistrate Liu's son (allegedly Liu Tzu-han)

Mrs. Shen, mother of Ko P'in-lien

Shen T'i-jen, second husband of Mrs. Shen

Wang Hsin-p'ei, Shen T'i-jen's relative

Wang Lin, local constable and witness

Yu Ching-t'ien, witness

Ch'ien T'an, pharmacist (allegedly Ch'ien Pao-sheng)

Ho Ch'un-fang, alleged lover of Hsiao-pai-ts'ai

Chiang Wei-lung, yamen servant

Liu Tien-ch'en, yamen servant

\section{The Prefectural Review}

Ch'en Lu, Prefect

\section{Provincial Reviews}

K'uai Ho-sun, Judicial Commissioner

Yang Ch'ang-chün, Governor of Chekiang

Cheng Hsi-kao, Expectant Magistrate sent to Yü-hang

\section{Governor Yang's Investigating Committee}

Hsi Kuang, Prefect of Hu-chou

Kung Chia-chün, Prefect of Shao-hsing

Sun Hsiang-fu, Expectant Prefect

Hsü Chia-te, Magistrate of Fu-yang

Ch'en Pao-shan, Magistrate of Huang-yen 
Imperial Reviews

The Throne

The Kuang-hsü Emperor

The Empress Dowager, Tz'u-hsi

Censors

Wang Shu-jui

Pien Pao-ch'üan

Wang Hsin

Imperial Investigators

$\mathrm{Hu}$ Jui-lan, Literary Chancellor

Pien Pao-hsien, Prefect of Ning-po

Lo Tzu-sen, Magistrate of Chia-hsing

$\mathrm{Ku}$ Te-heng, Expectant Magistrate

Kung Shih-t'ung, Expectant Magistrate

Board of Punishments

Sang Ch'un-jung, Board President

Tsao-pao, Board President

Weng T'ung-ho, Board Vice President and imperial tutor

Hsia T'ung-shan, Board Vice President

Tsao-chi, Board Vice President

Yu Chuan, Director of the Autumn Assizes

Lim Kung-shu, middle-level official

Coroners at the Capital

Sun I

Lien Shun

\section{Other Imperial Officials}

Pao-yün, Imperial Grand Secretary

Ting Pao-chen, Governor General of Szechuan

Other Natives of Chekiang Involved in the Case

-Wang Shu-p'ing, Imperial Chancellery Secretary

Chung Po-sheng, Hanlin Academy Sub-reader

Wang Ming-luan, Imperial Academy Tutor

Wu Chung-yü, Yü-hang resident who discussed the case with Weng T'ung-ho 